\title{
WUI Structure/Parcel/Community Fire Hazard Mitigation Methodology
}
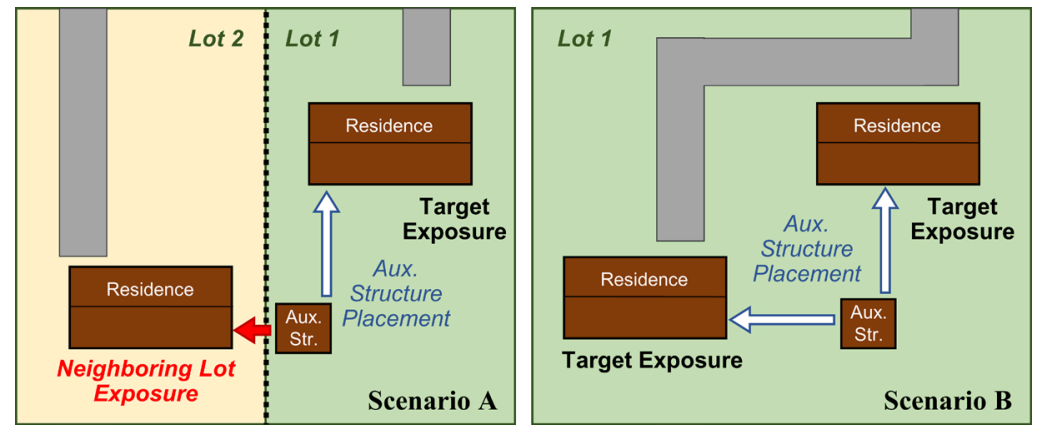

Alexander Maranghides

Eric D. Link

Steven Hawks

Jim McDougald

Stephen L. Quarles

Daniel J. Gorham

Shonali Nazare
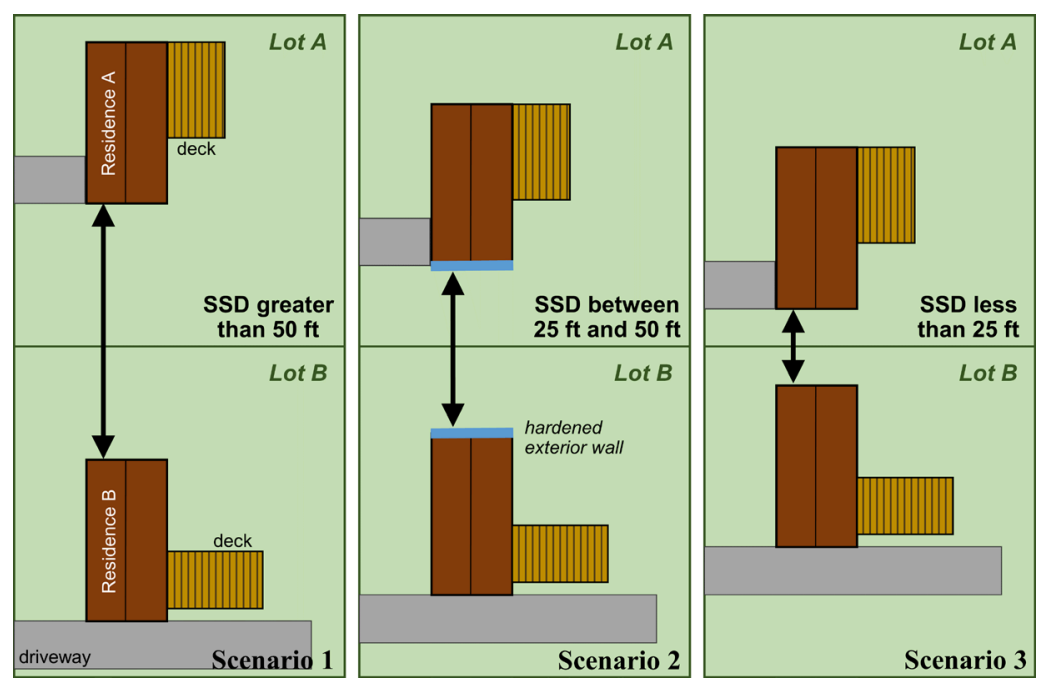

This publication is available free of charge from: https://doi.org/10.6028/NIST.TN.2205

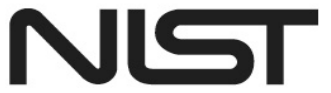

National Institute of Standards and Technology U.S. Department of Commerce 


\title{
WUI Structure/Parcel/Community Fire Hazard Mitigation Methodology
}

\author{
Alexander Maranghides \\ Eric D. Link \\ Shonali Nazare \\ Engineering Laboratory, NIST \\ Steven Hawks \\ Jim McDougald \\ California Department of Forestry and Fire Protection (CAL FIRE) \\ Stephen L. Quarles \\ Daniel J. Gorham \\ Insurance Institute for Business \& Home Safety (IBHS)
}

This publication is available free of charge from:

https://doi.org/10.6028/NIST.TN.2205

March 2022

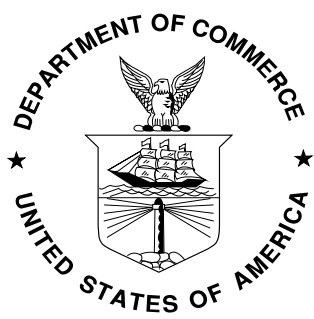

U.S. Department of Commerce Gina M. Raimondo, Secretary

National Institute of Standards and Technology James K. Olthoff, Performing the Non-Exclusive Functions and Duties of the Under Secretary of Commerce for Standards and Technology \& Director, National Institute of Standards and Technology 
Certain commercial entities, equipment, or materials may be identified in this document in order to describe an experimental procedure or concept adequately. Such identification is not intended to imply recommendation or endorsement by the National Institute of Standards and Technology, nor is it intended to imply that the entities, materials, or equipment are necessarily the best available for the purpose.

NIST policy is to use the International System of Units (SI) in all publications. However, in this document, units are presented in the system prevalent in the relevant discipline, although in some cases more than one system of units may be presented.

National Institute of Standards and Technology Technical Note 2205 Natl. Inst. Stand. Technol. Tech. Note 2205, 77 pages (March 2022) CODEN: NTNOEF

This publication is available free of charge from: https://doi.org/10.6028/NIST.2205 


\begin{abstract}
In the last twenty years, wildland-urban interface (WUI) fires have grown in severity and size. The structures destroyed by WUI fires have devastated entire communities and have cost billions of dollars while significantly impacting the social fabric and economic wellbeing of entire regions. Structure losses are attributed to exposures from both embers (firebrands) and fire (radiation and/or convection). As structure losses continue to increase, there is a growing need for a comprehensive hazard assessment and mitigation methodology to harden appropriate structures and parcels effectively and efficiently against ember and fire exposures. To address this need, the National Institute of Standards and Technology (NIST), the California Department of Forestry and Fire Protection (CAL FIRE), and the Insurance Institute for Business \& Home Safety (IBHS) embarked on a sixteen-month collaborative effort, culminating in this Hazard Mitigation Methodology (HMM).
\end{abstract}

The HMM provides an implementable path forward by considering the spatial relationships between fuels, exposures, and hardening at the structure and parcel levels. The HMM demonstrates how complex structure hardening is, and how and why hazards associated with both fire and ember exposures need to be mitigated. By describing the relationships between exposure and hardening within the methodology, HMM highlights situations where structure hardening does not provide sufficient protection in the absence of parcel hardening. The HMM also addresses housing density, structure separation distance, and parcel layouts. The methodology was explicitly designed to address the current building stock, i.e., to solve retrofit challenges, and efforts were made to limit retrofit expenses. While the methodology was developed primarily for retrofits, the presented strategy can also be applied to new construction.

This science-based methodology uses the knowledge collected from post-fire field observations spanning a dozen years and tens of thousands of hours of field data integration and analysis. Additionally, the HMM utilizes the latest technical knowledge gained from laboratory and large-scale research in fire propagation and hazard mitigation in the WUI.

This report documents the methodology and addresses the critical issues of mitigation effectiveness at the parcel and community levels. The impacts of partial mitigation at the parcel and community level were addressed for different types of WUI communities.

\title{
Key words
}

community hazard reduction; disaster resilience; ember; firebrand; hazard mitigation; large outdoor fires; parcel hardening; retrofit; structure separation distance; wildfire; wildlandurban interface; WUI 
Table of Contents

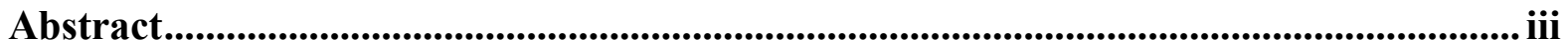

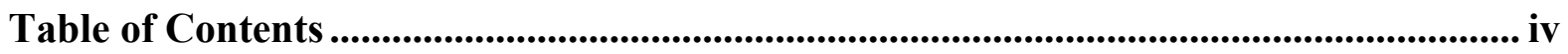

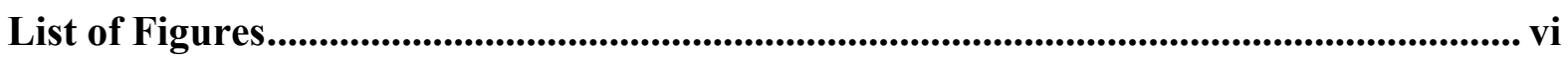

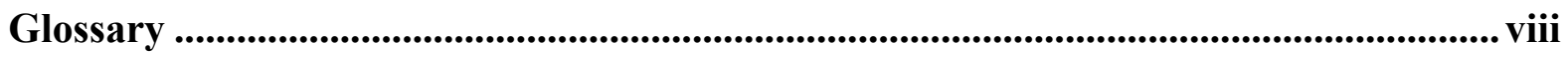

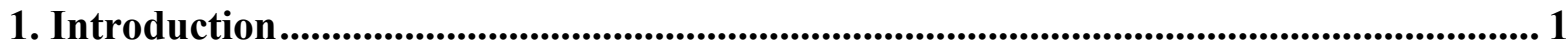

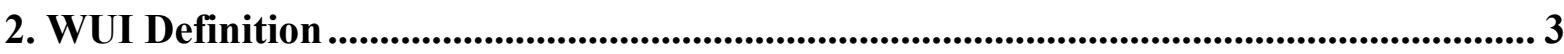

3. Defining WUI by Structure Separation Distance .................................................. 7

4. WUI Hazard Mitigation Methodology ................................................................. 16

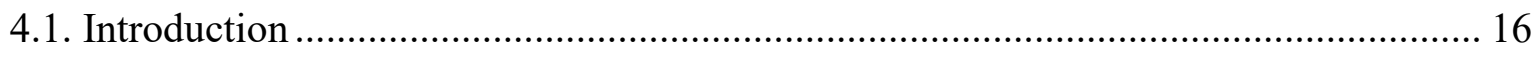

4.2. Quantifying Ember and Fire Exposures .............................................................. 17

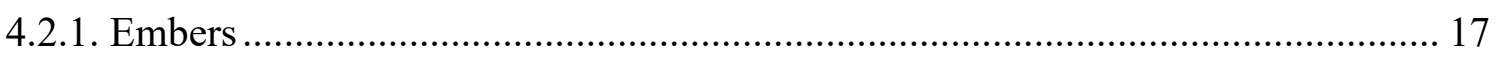

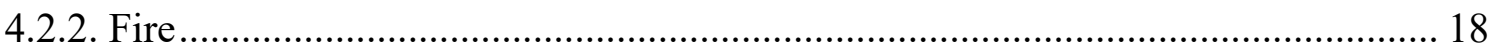

4.3. Structure Ignition Pathways .................................................................................... 19

4.3.1. Impact of Parcel Boundaries on Code Application .......................................... 20

4.3.2. Impact of Linear Features on Fire Spread ..................................................... 21

4.3.3. Impact of Fuel Agglomeration on Fire Spread .............................................. 23

5. Hazard Mitigation at the WUI...................................................................................... 27

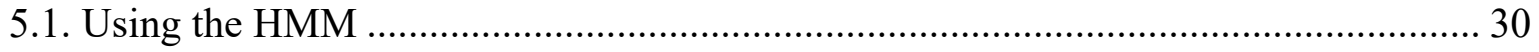

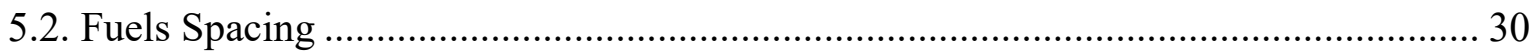

5.3. Fuel Density in Different WUI Types................................................................... 34

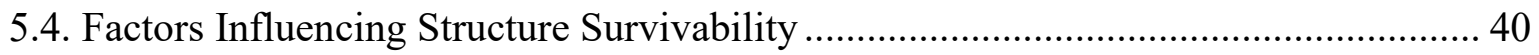

5.4.1. Effects of Defensive Actions on Structure Survivability ................................... 40

5.4.2. Impacts of Structure Mitigation Compliance on Structure Resilience ................. 41

5.4.3. Impacts of Community Mitigation Compliance on Community Resilience ......... 42

5.4.4. Effects of Housing Density on Mitigation Strategies .......................................... 43

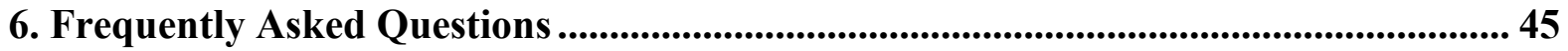

7. Comparison of this Hazard Mitigation Methodology with National and International

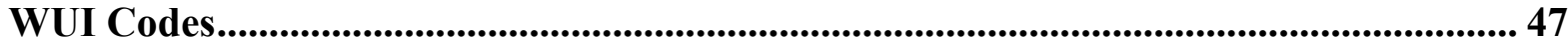

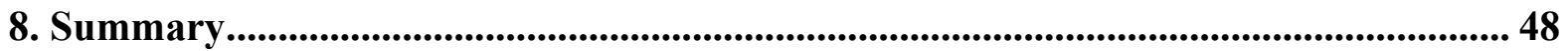

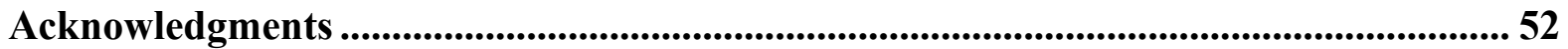

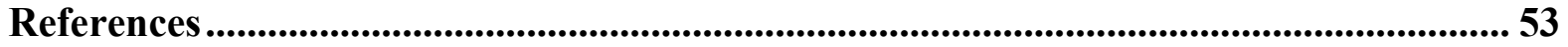

Appendix A. Home Hardening Requirements ......................................................... 57

Appendix B. Comparison of Existing Codes and Standards ..................................... 65 


\section{List of Tables}

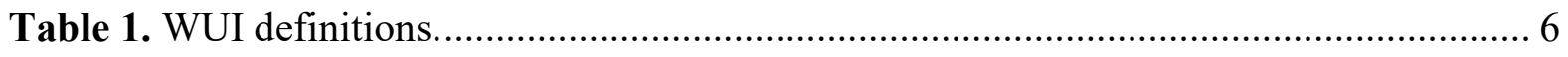

Table 2. WUI Types classified by structure separation distance (SSD) and typical parcel size.

Table 3. Structure and parcel hardening effectiveness.......................................................... 29

Table 4. Parcel layout and fuel placement in different WUI Types visualized in Figures 17

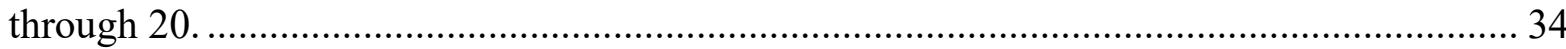

Table 5. Defensive actions identified in NIST post-fire case studies. .................................. 40

Table 6. HMM items completely included in selected existing WUI building codes. .......... 47

Table A. Structure and attached combustible hardening against ignition from embers. …... 58

Table B. Surrounding parcel hazard mitigation - hardening structure and attached combustibles against ignition from fire (radiation, convection)........................................... 62

Table C. Primary parcel hazard mitigation - hardening structure and attached combustibles

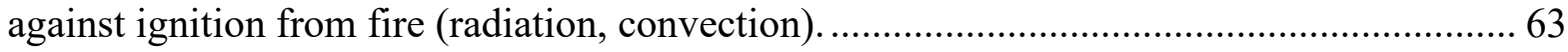

Table D. Structure hazard mitigation - hardening structure and attached combustibles against

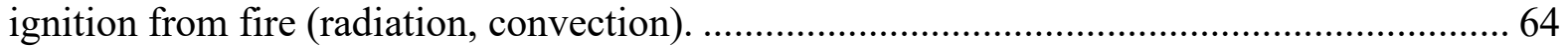

Table E. Comparison of selected existing WUI building codes. ........................................... 66 


\section{List of Figures}

Figure 1. The neighborhood of Coffey Park in Santa Rosa, CA is an example of WUI Type 2 (High Density Interface - Interior). For SI: $1 \mathrm{ft}=0.305 \mathrm{~m}, 1 \mathrm{ac}=0.4$ ha........................ 9

Figure 2. An example of structure density of the Mountain Shadows neighborhood in Colorado Springs, CO is shown in Map Figure 13 from NIST TN 1910 [4] (units modified). Insets show the highest density area (yellow) and associated lot size distribution. 10

Figure 3. Varying structure separation distances in the Mountain Shadows neighborhood of Colorado Springs, CO are shown in Map Figure 14 from NIST TN 1910 [4] (units modified). The inset highlights an area of very low SSD. For SI: $1 \mathrm{ft}=0.305 \mathrm{~m}, 1 \mathrm{ac}=0.4$ ha.......... 11

Figure 4. WUI Type 6: Low Density Intermix Rancho Santa Fe, CA............................... 12

Figure 5. WUI Type 6: Low Density Intermix, The Trails, Rancho Bernardo, CA. Note irrigated lawns, long paved driveways, pools and tennis courts. Some structure-to-structure distances are representative of Moderate Density Intermix (lower part of image). Also note limited high density non-irrigated vegetative loading.

Figure 6. WUI Type 6: Low Density Intermix: Concow, CA. Note the overall large SSD and structures located within the wildland vegetation. Note the imagery is taken after the 2018 Camp Fire.

Figure 7. WUI fire hazard mitigation is a balance between two input dials — reducing exposure and increasing structure hardening.

Figure 8. Parcel-level combustible features that can contribute to various structure ignition pathways. Highlighted in white are hazards that NIST and IBHS have performed extensive study of.

Figure 9. Existing codes are parcel centric. Residential structures are similarly located in Scenario A and B; however, the parcel division in Scenario A allows placement of an auxiliary structure too close to the neighboring primary structure when the parcels are considered independently

Figure 10. Illustration of numerous fire spread pathways among neighboring parcels via linear features and other combustibles. Inset photographs are from field observations and experiments.

Figure 11. Parallel western red cedar fences burning with an applied wind of $13 \mathrm{mi} / \mathrm{h}(6 \mathrm{~m} / \mathrm{s})$ (left two images) compared to a single burning fence (right).

Figure 12. Spatial relationships between fuels on two adjacent parcels. Sheds are spaced appropriately from the residences and other fuels, except fences, on their respective lots. However, Shed $A-1$ is too close to Residence $B$, and both sheds act as an agglomerated fuel package along the property border. The sheds and fences will substantially increase the exposures from the red highlighted area, igniting the structures.

Figure 13. Fuel on Lot $B$ is adequately spaced from Residence $B$; however, fuel is agglomerated at the fence, which opens the pathway to Residence A. Ignition on Lot B may still result in pathway shown, gazebo $\rightarrow$ fence $\rightarrow R V \rightarrow$ Residence $A$, despite noncombustible fence attachments on both residences. 
Figure 14. Illustration, based on an actual WUI community, showing real world fuel agglomeration and nominal $8 \mathrm{ft}$ SSD on high-density parcels. Illustrated conditions extend across the street and throughout the community (not pictured). Fuel continuity is present across the community of hundreds of homes.

Figure 15. Three scenarios with a range of SSDs between the primary residence and auxiliary structure $>120 \mathrm{ft}^{2}:$ 1) greater than $50 \mathrm{ft}, 2$ ) between $25 \mathrm{ft}$ and $50 \mathrm{ft}$, and 3) under $25 \mathrm{ft}$. Structure hardening to increase ignition resistance is illustrated in blue (Scenario 2). Note that hardening is directional and is not necessarily required around the entire structure. Hardening for embers is required in all scenarios.

Figure 16. Three scenarios with a range of SSDs: 1) greater than $50 \mathrm{ft}, 2$ ) between $25 \mathrm{ft}$ and $50 \mathrm{ft}$, and 3) under $25 \mathrm{ft}$. Structure hardening to increase ignition resistance illustrated in blue (Scenario 2). Note that hardening is directional and is not required completely around both structures. Hardening for embers is required in all scenarios.

Figure 17. Scenario A, WUI Type 2. Small parcel with small SSD provides minimal space for auxiliary fuels. The shed is located closer to the neighboring residence than the owner's residence.

Figure 18. Scenario B, WUI Type 4. Moderate density interface. In some areas there is limited space for auxiliary fuels, shown by the agglomeration on the property boundaries (red highlights). The area highlighted in blue presents reduced impact on residential structures. The lower figures show before and after fire imagery with the actual fire spread pathway highlighted.

Figure 19. Scenario C, WUI Type 4 or Type 6 . While the structures are placed on large parcels with extensive backyards, the primary structures are very large with considerably smaller SSD. Selective hardening may be required in this scenario despite the large parcels.

Figure 20. Scenario D, WUI Type 6. This community is characterized by large parcels with more extensive space available for auxiliary fuels. Avoidance of agglomeration of fuels within the outlined areas would influence the total number of auxiliary fuels allowed in these spaces. 


\section{Glossary}

\section{Abbreviations}

AHJ authority having jurisdiction

CA Chapter 7A a chapter in the California Building Code establishing minimum standards for construction in state-designated areas, titled Materials and Construction for Exterior Wildfire Exposure

CAL FIRE California Department of Forestry and Fire Protection

FRAP Fire and Resource Assessment Program (CAL FIRE)

FSD fuel separation distance - the spatial distance between a fuel (source) and a target

FSR fuel separation range - the spatial distance between a fuel and target in which hardening of the target will significantly reduce target ignition potential

ICC International Code Council

IBHS Insurance Institute for Business \& Home Safety

NFPA National Fire Protection Association

NIST National Institute of Standards and Technology

SSD structure separation distance - the distance between two structures (primary or auxiliary)

\section{Terms}

cladding the exterior materials or assembly of materials of a structure

ember a hot or burning (flaming or smoldering) particle generated/broken off from the source (due to impact, wind, or the reduced structural integrity of the solid fuel due to burning)

exposure the heat energy from flames, radiation, and/or embers that are generated from a burning object, feature, or structure

firebrand see ember; particularly an airborne ember

parcel a specific plot of land with delineated boundaries, typically containing a house or building

source an object, feature, or structure that, when burning, generates an exposure of heat, flames, and embers

target the recipient of an exposure - may be a structure (hardened or nonhardened) or other parcel features

wildlands any undeveloped land with vegetative fuels that can generate fire and ember exposures (may also be located on partially developed parcels) 


\section{Introduction}

Fires in the wildland-urban interface (WUI) pose a growing threat to communities across the nation and around the world. Fires have grown in intensity and size in the last 20 years [1-3]. Additionally, a new threat has emerged from fire storms, events where tens of fires can occur simultaneously, creating challenging conditions for first responders that result in reduced response coverages. Recent events include the October 2017 North Bay Fires and the August 2020 lightning fires in California, as well as the September 2020 fires in Oregon. As losses mount, a paradigm shift of the hazard mitigation approaches that have been widely used to date is needed.

Fire and embers vary over small geospatial scales in WUI fire events. Post-WUI fire case studies have identified that these exposures can vary on a sub-parcel scale, on the order of $50 \mathrm{ft}$ to $100 \mathrm{ft}$, highly dependent on localized fuel, wind, and topographic conditions [4-6]. Embers can travel several miles, and initial low to moderate ember exposures can impact entire communities $[7,8]$. These initial wildland exposures can significantly contribute to the spread of fire into the community directly, or through the development of significant fire exposures from the ignition of fuels within the community. Subsequent ignitions within communities can generate localized very high ember exposures. Fire (radiation and convection) exposures can also exhibit significant variations occurring over several feet. This is not only a function of the spatial distribution of fuels but also is associated with the rapid decay in radiation intensity with increasing distance and the limited extent of flaming combustion (i.e., flame length) compared to the widespread extent of ember exposures. National Institute of Standards and Technology (NIST) WUI case studies have repeatedly identified the need to couple exposures to structure hardening [4-6]. A Hazard Mitigation Methodology (HMM) was developed to address this specific need and was a sixteen-month collaborative effort by NIST, the Insurance Institute for Business \& Home Safety (IBHS), and the California Department of Forestry and Fire Protection (CAL FIRE).

All WUI communities are not the same. This HMM goes beyond the traditional WUI definitions and introduces the concept of structure separation distance (SSD) for the development and implementation of hazard reduction. The proposed HMM accounts for both ember and flaming exposures in the WUI and addresses the spatial relationships between fuels that drive the ignition of structures and fire propagation. This work represents the technical evolution of the NIST WUI Hazard Scale [9] published in 2013. Scientific developments and field observations have resulted in the increase in spatial resolution of the proposed methodology as compared to the WUI Hazard Scale.

The goal of the HMM is to reduce the overall implementation burden by assessing local exposures and applying the latest laboratory research findings and knowledge from post-fire field observations to effectively harden structures in a cost-effective way. The HMM is primarily aimed at retrofitting the existing building stock. The proposed methodology also highlights the needs and requirements for implementation at the community level. 
HMM was designed to be applied in communities located in hazardous fire prone WUI areas. The benefits of community-wide mitigation can be viewed as proportional to the overall community fire hazard, including fire exposures from surrounding and occluded wildlands. While the implementation of HMM in a high-hazard community will likely substantially reduce losses, significant benefits can also be achieved in lower hazard scenarios. Recent WUI fires have demonstrated that significant losses can occur in low-hazard WUI or urban settings. One example is the impact of the 2017 Tubbs Fire on the Coffey Park community in Santa Rosa, CA.

NIST and IBHS are non-regulatory entities, while CAL FIRE has regulatory authority in the state of California. This HMM was developed to provide authorities having jurisdiction (AHJs) and homeowners with the latest comprehensive understanding of fire behavior and structure response in the WUI. When terms such as "required" and "should" are used, they are only in the context of highlighting the necessary components identified for the HMM to work. AHJs will ultimately choose where to implement any or all of the components presented in the HMM. 


\section{WUI Definition}

The common conceptual definition of wildland-urban interface (WUI) is the geographical area where human development, including structures and other infrastructure, meets or intermixes with undeveloped wildlands $[10,11]$. Communities in such areas may be grouped into one of three categories - interface, intermix, or occluded ${ }^{1}$ - depending on the density of development, coverage of wildland fuels, and population density [12]. This definition has been adopted by several governing federal- and state-level authorities and codes/standards organizations, including the US Fire Administration, the International Code Council (ICC) International Wildland-Urban Interface Code (IWUIC), and the National Fire Protection Association (NFPA).

Beyond the conceptual definition, establishing a uniform operational definition has proven difficult [13-15]. WUI areas are often delineated using three primary components:

1. human presence, often quantified by housing density or population density

2. wildland vegetation, often quantified by percentage of land coverage

3. proximity to wildlands, often quantified as a buffer distance between wildlands and developed land or structures.

The introduction of an official Federal WUI definition is presented in the Federal Register in 2001 [11] in support of Federal wildland fuel management efforts in response to the fire season of 2000. This definition quantified human presence through either housing density or population density. However, these definitions only qualitatively describe the quantity of wildland vegetation and proximity to wildlands.

The Healthy Forests Restoration Act (HFRA) of 2003 [16] slightly expanded the WUI definition to include "at-risk communities"-groups of homes or structures with basic infrastructure and services where there is a significant threat, to human life or property, from large-scale wildland fires. ${ }^{2}$ The WUI extends at least $0.5 \mathrm{mi}(0.8 \mathrm{~km})$ from the boundary of such areas and includes any additional area within $1.5 \mathrm{mi}(2.4 \mathrm{~km})$ consisting of topography or fuel accumulation conditions with increased potential for elevated fire behavior, or land suitable for effective firebreaks. Furthermore, the HFRA also deemed areas adjacent to evacuation routes from such communities as WUI.

Several studies have implemented the federal definition into practice to identify, quantify, and map WUI areas [14, 17-21]. The generally accepted defining criteria are presented in Table 1. However, even while adhering to the spirit of the Federal Register definition, slightly differing assumptions, interpretations of the thresholds, differing data sources, and intermediate data processing steps yield different outcomes [20-23]. Detailing specifics of the

\footnotetext{
${ }^{1}$ Occluded community refers to a situation where developed areas surround an island of wildland fuels generally $<1000$ ac (400 ha) in size [11]. These communities are typically treated and defined similar to interface communities.

${ }^{2}$ Note that both the Federal Register [11] and the HFRA [16] specify communities within or adjacent to federal lands. However, it is important to note that this reflects jurisdictional limitations and should not be understood to limit the broader sense of qualification/definition as WUI.
} 
various implementations are beyond the scope of this document. However, the focus of the mapping studies, and the federal definition in general, is to provide a high-level overview and a sense of scale to help progress to the next step - directing the additional focus needed to hone in on and support direct mitigation efforts in areas where it is needed.

It is important to note that not all communities in the WUI have the same fire risk level, and risk or threat is not quantified or defined in the Federal Register or the HFRA. However, the Federal Register does suggest the consideration of the following three broad categories when evaluating risk factors:

1. Fire behavior potential (e.g., fuel types and distribution, slopes, prevailing winds)

2. Values at risk (e.g., structures, watershed, cultural/historical values), and

3. Infrastructure (e.g., road access/egress, water supply, firefighting capacity).

While the above three risk factors provide useful information for assessing risk, the specific implementation criteria impact the final perimeters of WUI areas determined by local jurisdictions. Historically, WUI fire losses have occurred within these defined boundaries; it has been shown that a significant fraction of buildings destroyed by wildfires are located in the WUI [24]. However, it is also essential to keep in mind that hazardous conditions may extend beyond the "defined" WUI. For example, the Coffey Park neighborhood of Santa Rosa, CA, which was destroyed in the 2017 Tubbs Fire, sits outside the edge of the interface definition implemented by Radeloff et al. [17]. Once into the high-density structures, the fire burned $0.9 \mathrm{mi}$ beyond the interface limit into developed lands. Coffey Park losses illustrate the potential of a WUI fire to morph into an urban conflagration. Similar losses from structure-to-structure fire spread have been observed during many other large-loss WUI fire events whether the locations are designated WUI or not.

HMM was designed to be applied in communities located in hazardous fire prone WUI areas. State and local fire hazard severity mapping systems can be used to identify communities that can benefit from the application of this HMM. Some jurisdictions, such as the State of California, characterize hazard in their definition of WUI. The CAL FIRE Fire and Resource Assessment Program (FRAP) classifies land into Fire Hazard Severity Zones (FHSZ) [25, 26]. There are 3 levels of FHSZ - Moderate, High, and Very High — which are determined by analyzing several factors, including vegetation, fuel loading, topography, weather (temperature, humidity, and wind), fire history, and ember potential. The state uses the defined FHSZs to require building code provisions (i.e., California Building Code (CBC) Chapter 7A [27], California Fire Code Chapter 49 [28]) and hazard mitigation actions [29].

Efforts to define and map WUI hazard areas are necessary to assist local agencies in understanding their jurisdiction's wildfire hazards and to prepare their communities by focusing broad mitigation strategies and land use planning. However, fire behaves at many scales, and fire hazard at the structure or property level is often difficult to quantify using coarse scale data such as LANDFIRE [30]. 
Structure survivability is the result of the relationship between the structure construction and local intensity and duration of fire and ember exposures. Communities should assess both components in the process of structure and community hardening. As this HMM details, mitigation and hazard assessment distill down to a structure-level issue, and thus, considering structure separation distance as a defining component of WUI fire hazard is a logical progression for determining necessary hazard mitigation. 
Table 1. WUI definitions.

\begin{tabular}{|c|c|c|c|c|}
\hline & Definition Component & Federal Register & Common Implementation & CAL FIRE \\
\hline \multirow{6}{*}{ : } & Conceptual & $\begin{array}{l}\text { There is a clear line of demarcation between } \\
\text { residential, business, and public structures and } \\
\text { wildland fuels; wildland fuels do not generally } \\
\text { continue into the developed area }\end{array}$ & $\begin{array}{l}\text { Developed land not dominated } \\
\text { (i.e., }<50 \% \text { ) by vegetation }\end{array}$ & $\begin{array}{l}\text { High-density development adjacent to } \\
\text { undeveloped wildland vegetation }\end{array}$ \\
\hline & Housing density & $\geq 3$ structure $/$ ac $\left(741\right.$ structure $/ \mathrm{km}^{2}$ ) & $\geq 1 \mathrm{HU} / 40 \mathrm{ac}\left(6.18 \mathrm{HU} / \mathrm{km}^{2}\right)$ & $\begin{array}{l}>1 \mathrm{HU} / 20 \text { ac }\left(12.4 \mathrm{HU} / \mathrm{km}^{2}\right) \text { in } \\
\text { Moderate, High, or Very High FHSZ }\end{array}$ \\
\hline & Population density & $\geq 250$ people $/ \mathrm{mi}^{2}\left(96\right.$ people $\left./ \mathrm{km}^{2}\right)$ & & \\
\hline & Vegetation cover & Structures directly abut wildland fuels & $<50 \%$ & Not dominated by wildland vegetation \\
\hline & Buffer from wildland & Up to $1.5 \mathrm{mi}(2.4 \mathrm{~km})$ from community border & $\begin{array}{l}<1.5 \mathrm{mi}(2.4 \mathrm{~km}) \text { from land } \\
\text { with }>75 \% \text { vegetative cover }\end{array}$ & $\begin{array}{l}\text { Wildfire susceptible vegetation up to } \\
1.5 \mathrm{mi}(2.4 \mathrm{~km}) \text { from interface }\end{array}$ \\
\hline & Infrastructure & $\begin{array}{l}\text { Fire protection of the structures from both an } \\
\text { interior fire and an advancing wildland fire } \\
\text { provided by the local fire department. }\end{array}$ & & \\
\hline \multirow{6}{*}{ 番 } & Conceptual & $\begin{array}{l}\text { There is no clear line of demarcation; wildland } \\
\text { fuels are continuous outside of and within the } \\
\text { developed area }\end{array}$ & $\begin{array}{l}\text { Developed land dominated (i.e., } \\
>50 \% \text { ) by vegetation }\end{array}$ & $\begin{array}{l}\text { Lower-density housing mingled with } \\
\text { undeveloped wildland vegetation }\end{array}$ \\
\hline & Housing density & $\geq 1$ structure $/ 40$ ac $\left(6.18\right.$ structure $\left./ \mathrm{km}^{2}\right)$ & $\geq 1 \mathrm{HU} / 40 \mathrm{ac}\left(6.18 \mathrm{HU} / \mathrm{km}^{2}\right)$ & $\begin{array}{l}1 \mathrm{HU} / 20 \mathrm{ac} \text { to } 1 \mathrm{HU} / 5 \mathrm{ac} \\
\left(12.4 \mathrm{HU} / \mathrm{km}^{2} \text { to } 50 \mathrm{HU} / \mathrm{km}^{2}\right) \text { OR } \\
>1 \mathrm{HU} / 5 \mathrm{ac}\left(50 \mathrm{HU} / \mathrm{km}^{2}\right) \text { when } \\
\text { dominated by wildland vegetation, } \\
\text { in Moderate, High, or Very High FHSZ }\end{array}$ \\
\hline & Population density & (28 to 250 ) people $/ \mathrm{mi}^{2}\left[(11\right.$ to 96$)$ people $\left./ \mathrm{km}^{2}\right]$ & & \\
\hline & Vegetation cover & $\begin{array}{l}\text { Structures are scattered throughout a wildland } \\
\text { area }\end{array}$ & $>50 \%$ & Dominated by wildland vegetation \\
\hline & Buffer from wildland & & & $\begin{array}{l}\text { Wildfire susceptible vegetation up to } \\
1.5 \mathrm{mi} \text { from intermix }\end{array}$ \\
\hline & Infrastructure & $\begin{array}{l}\text { Fire protection districts provide life and } \\
\text { property protection and may also have wildland } \\
\text { fire protection responsibilities }\end{array}$ & & \\
\hline
\end{tabular}

Note: $\mathrm{HU}=$ housing units 


\section{Defining WUI by Structure Separation Distance}

The WUI environment is complex and multifaceted. Several definitions of the WUI have been presented and used to meet specific documentation goals or to broadly identify hazard areas. For more focused and effective mitigation efforts, namely the enumeration of required structure hardening, many of these definitions are not sufficient on their own as they do not focus on the parcel-level details that characterize parcel-to-parcel and structure-to-structure fire spread. In this document, the definition of the WUI is subdivided into seven distinct types based on structure separation distance (SSD) and "traditional" WUI categories (i.e., interface or intermix). The Types are listed in Table 2. These definitions provide perspective and can help characterize overall community housing density and lot sizes. Table 2 can be applied at the community or the parcel level; however, Table $\mathbf{2}$ is not sufficient to implement the HMM.

The range of structure densities defined as WUI are extremely broad. A typical high-density community with $8 \mathrm{HU} /$ ac (housing units per acre) is 320 times denser than the lowest density typically considered WUI, $0.02 \mathrm{HU} / \mathrm{ac}$ ( $1 \mathrm{HU}$ on 40 acres). The agglomeration of structures ${ }^{3}$ seen in high-density communities (frequently resulting in small SSD) has significant impact on fire behavior $[4,31]$. The use of SSD as a key metric in characterizing WUI areas specifically with respect to fire is twofold. First, structures represent a significant density of fuels that impact fire spread and, in many cases, directly contribute to the ignition of additional structures, propagating fire throughout the community. Secondly, existing structures pose a unique challenge in hazard management - they are immobile. While they can be hardened (see Section 5 for mitigation methodology), they cannot be readily removed or displaced like many other WUI fuels.

The traditional WUI categories (interface/intermix) describe the general community classification and hazard profile. However, effective structure-level mitigation must be driven by parcel-level assessments and localized evaluation of potential fire exposures. This can be aided through identification of a parcel-level WUI Type. The Types listed in Table 2 are primarily defined by SSD, with secondary consideration of parcel size. Even if structures are located on a large lot but are clustered together on the edge of the property with small SSD, the parcel WUI Type would correspond to a smaller SSD.

\footnotetext{
${ }^{3}$ All structures, not just housing units, including primary (residential and commercial) and auxiliary (e.g., auxiliary dwelling units (ADUs), garages, sheds) structures impact fire spread.
} 
Table 2. WUI Types classified by structure separation distance (SSD) and typical parcel size.

\begin{tabular}{clccc}
\hline $\begin{array}{c}\text { Type } \\
\#\end{array}$ & WUI Type Name & SSD (ft) & $\begin{array}{c}\text { Typical } \\
\text { Parcel Size } \\
\text { (ac) }\end{array}$ & $\begin{array}{c}\text { Typical } \\
\text { Housing } \\
\text { Density } \\
\text { (struct/ac) }\end{array}$ \\
\hline 1 & $\begin{array}{l}\text { High Density Interface }- \\
\text { Perimeter }\end{array}$ & $6^{\mathrm{a}}$ to 30 & $<0.5$ & 2 to $8+$ \\
2 & $\begin{array}{l}\text { High Density Interface }- \\
\text { Interior }\end{array}$ & $6^{\mathrm{a}}$ to 30 & $<0.5$ & 2 to $8+$ \\
3 & $\begin{array}{l}\text { Medium Density Interface }- \\
\text { Perimeter }\end{array}$ & 30 to 100 & 0.5 to $1+$ & $<2$ \\
4 & $\begin{array}{l}\text { Medium Density Interface }- \\
\text { Interior }\end{array}$ & 30 to 100 & 0.5 to $1+$ & $<2$ \\
5 & $\begin{array}{l}\text { Medium Density Intermix } \\
6\end{array}$ & 30 to 100 & 0.5 to $1+$ & $<2$ \\
7 & Low Density Interface & $100+$ & $1+$ & $<1$ \\
\hline
\end{tabular}

For SI: $1 \mathrm{ft}=0.305 \mathrm{~m}, 1 \mathrm{ac}=0.4$ ha

${ }^{a}$ representative of parcels with a $3 \mathrm{ft}$ setback (common for new construction of sprinklered residences)

${ }^{b}$ interior of community defined as $>0.25 \mathrm{mi}(400 \mathrm{~m})$ from wildlands 


\section{WUI Type 1 and Type 2}

WUI Type 1 and Type 2 represent high-density interface communities. These communities have a high fraction of their fuel load in the form of residential structures. SSDs in these communities are often as little as $6 \mathrm{ft}$ (minimum $3 \mathrm{ft}$ building setback from property line) and up to $30 \mathrm{ft}$. These types of WUI can be found around the country including in some very high WUI fire hazard areas. These WUI communities typically have parcel sizes significantly less than 0.5 ac (0.2 ha). Communities like Coffey Park in Santa Rosa, CA (shown in Figure 1) or the Mountain Shadows area of Colorado Springs, CO are examples of these high-density communities. Typical lot sizes in these two communities are less than $0.15 \mathrm{ac}$, and typical $\mathrm{SSD}$ is $6 \mathrm{ft}$ (see maps and data in Figure 2 and Figure 3). The Mountain Shadows neighborhood can be characterized as Type 1 High Density Interface - Perimeter while Coffey Park can be characterized as a Type 2, High Density Interface - Interior community.

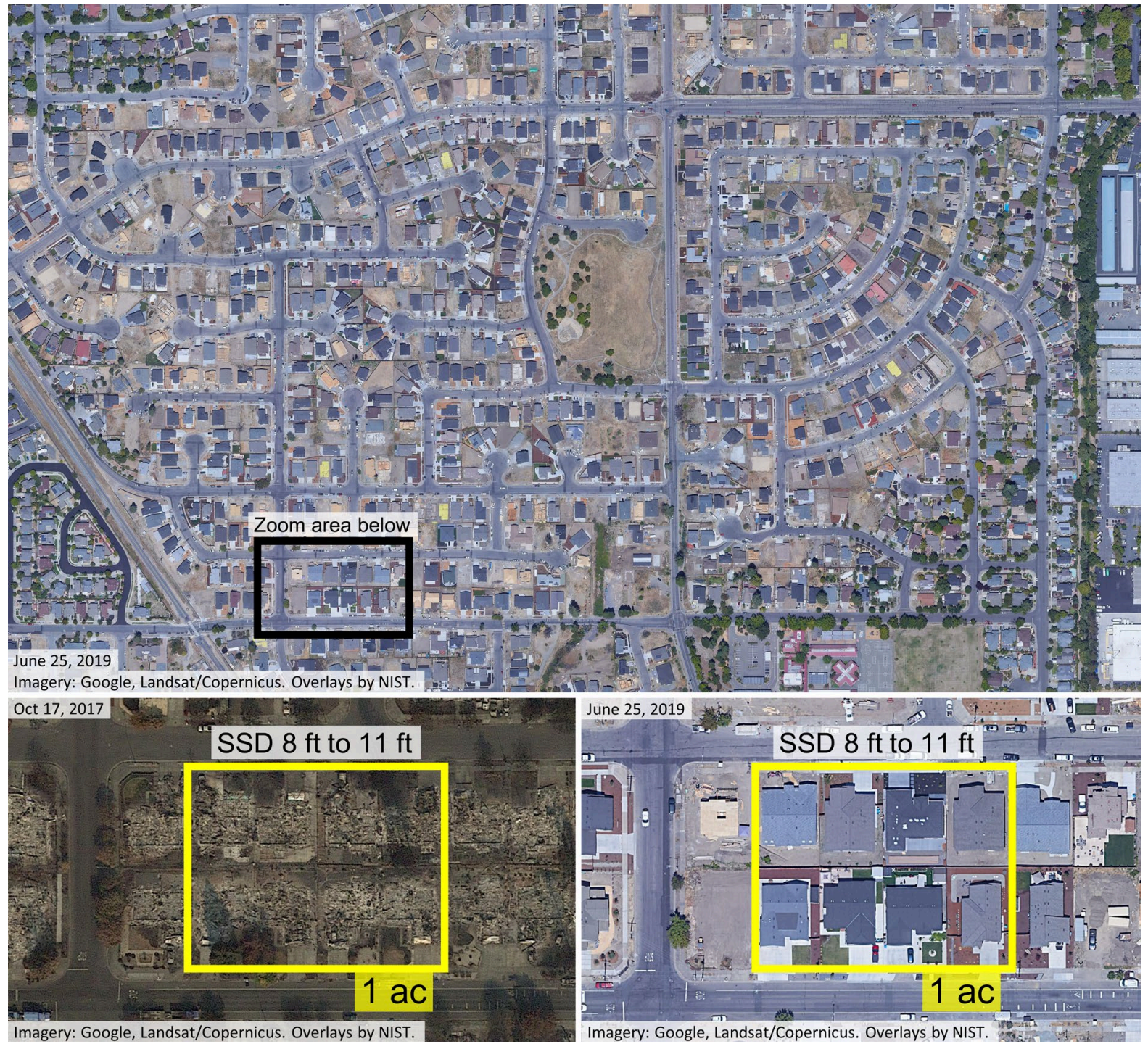

Figure 1. The neighborhood of Coffey Park in Santa Rosa, CA is an example of WUI Type 2 (High Density Interface - Interior). For SI: $1 \mathrm{ft}=0.305 \mathrm{~m}, 1 \mathrm{ac}=0.4$ ha. 


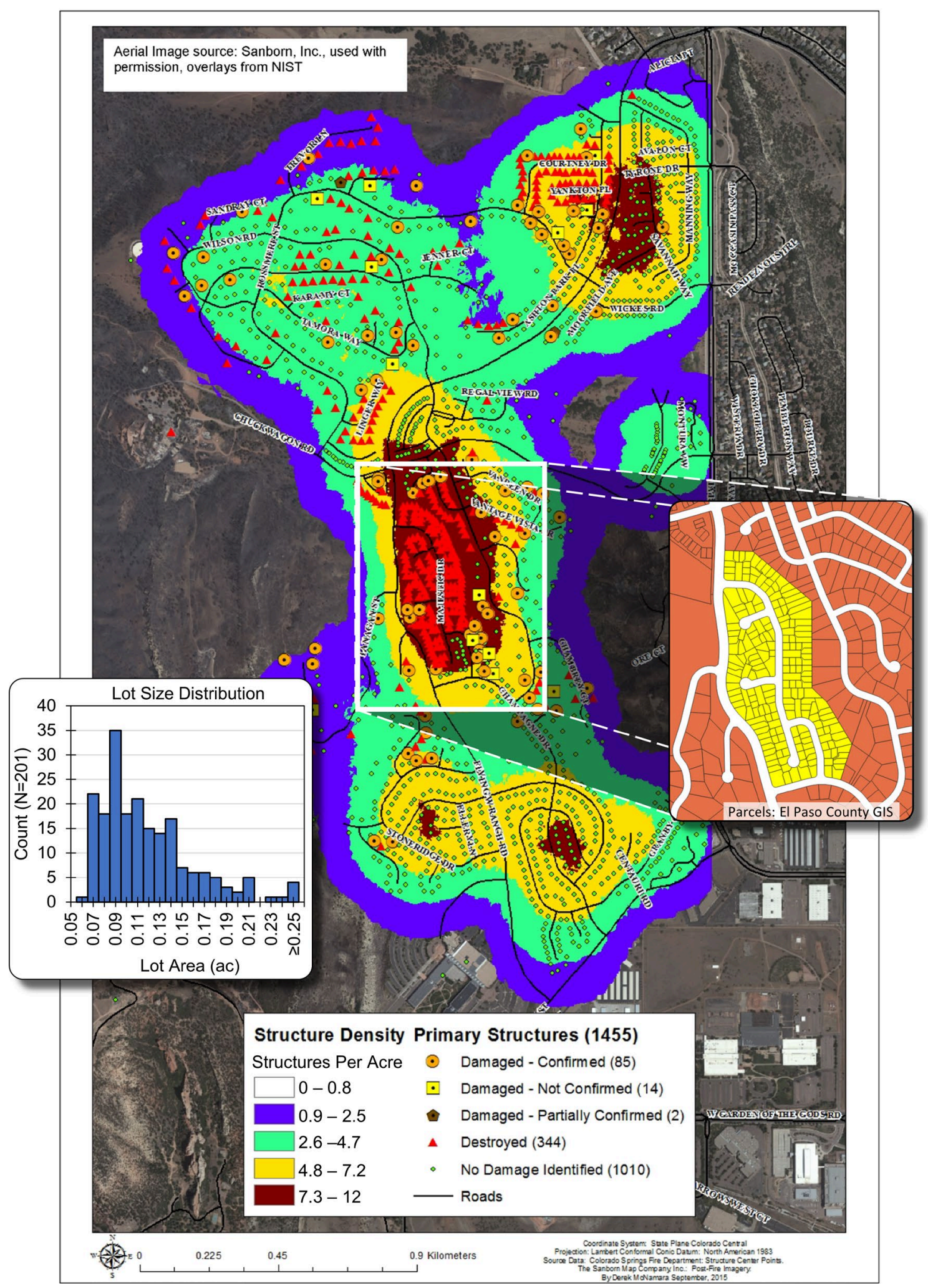

Figure 2. An example of structure density of the Mountain Shadows neighborhood in Colorado Springs, CO is shown in Map Figure 13 from NIST TN 1910 [4] (units modified). Insets show the highest density area (yellow) and associated lot size distribution. For SI: $1 \mathrm{ac}=0.4$ ha; 1 structure $/ \mathrm{ac}=2.47$ structure $/$ ha. 


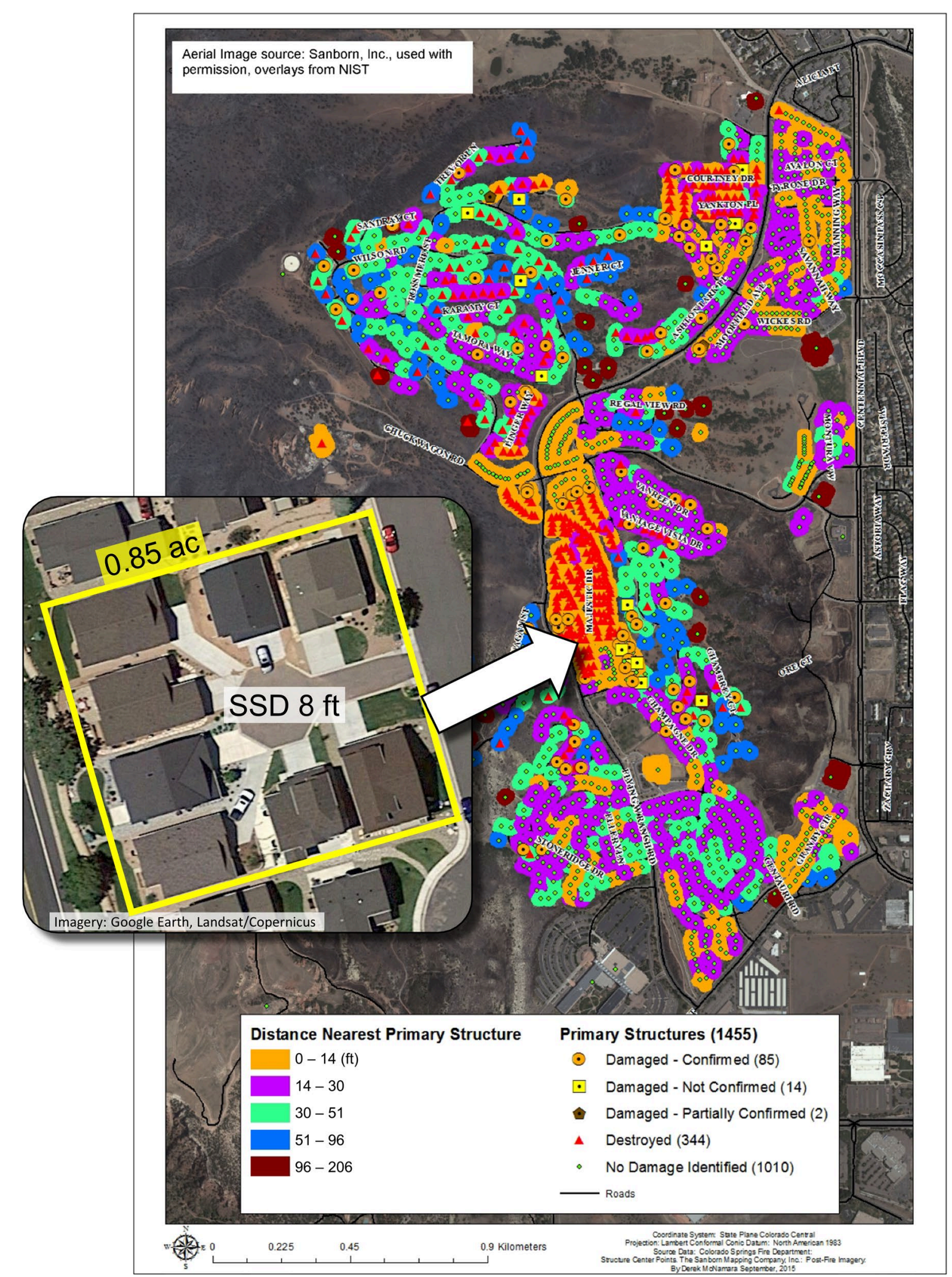

Figure 3. Varying structure separation distances in the Mountain Shadows neighborhood of Colorado Springs, CO are shown in Map Figure 14 from NIST TN 1910 [4] (units modified). The inset highlights an area of very low SSD. For SI: $1 \mathrm{ft}=0.305 \mathrm{~m}, 1 \mathrm{ac}=0.4 \mathrm{ha}$. 
WUI Types 3, 4, and 5 are all characterized by medium-density construction with SSD ranging from $30 \mathrm{ft}$ to $100 \mathrm{ft}$. Parcels are typically larger in the medium (or moderate) density WUI, with many being over 1 ac. These WUI Types are further subdivided; interface (Types 3 and 4) and intermix (Type 5). Like WUI Type 1 and Type 2, Medium Density Interfaces can be located on the perimeter abutting wildlands (Type 3 ) or in the interior of WUI interface communities (Type 4). WUI Type 5 represents medium density intermix communities with similar SSD found in Types 3 and 4 of $30 \mathrm{ft}$ to $100 \mathrm{ft}$.

\section{WUI Type 6 and Type 7}

WUI Types 6 and 7 are characterized by low structure density at the interface and intermix, respectively. These are low structure density locations where residential structures are typically over $100 \mathrm{ft}$ apart. ${ }^{4}$ These communities are comprised of larger lots, typically over 2 ac. Note that even within a WUI Type, structure and vegetation characteristics may be quite different. Figure 4, Figure 5, and Figure 6 show different examples of low-density intermix.

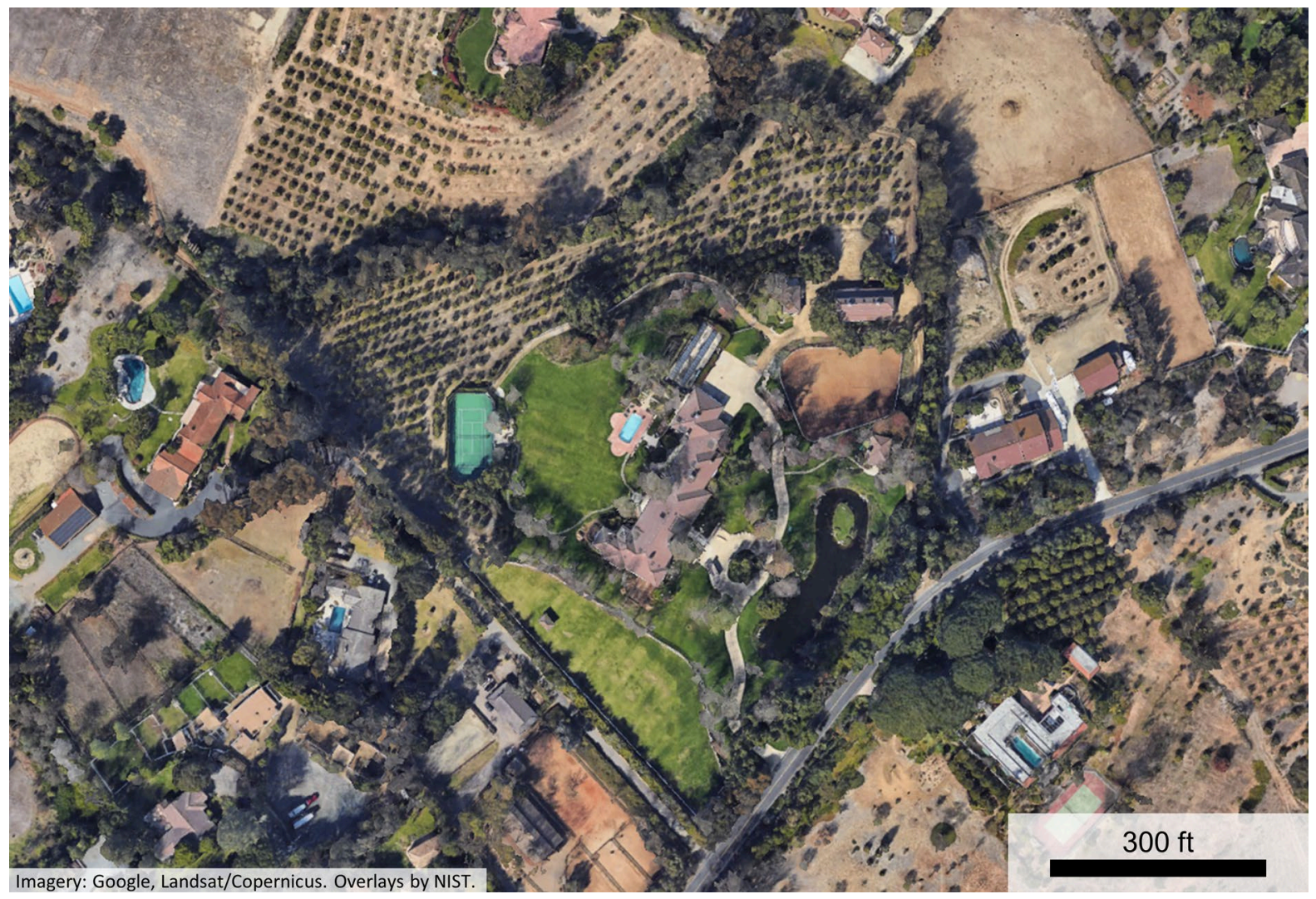

Figure 4. WUI Type 6: Low Density Intermix Rancho Santa Fe, CA.

\footnotetext{
${ }^{4}$ Auxiliary structures may be present and can have significant impact on fire spread. These local SSD (between all structures and other fuels) are explicitly addressed through the HMM.
} 


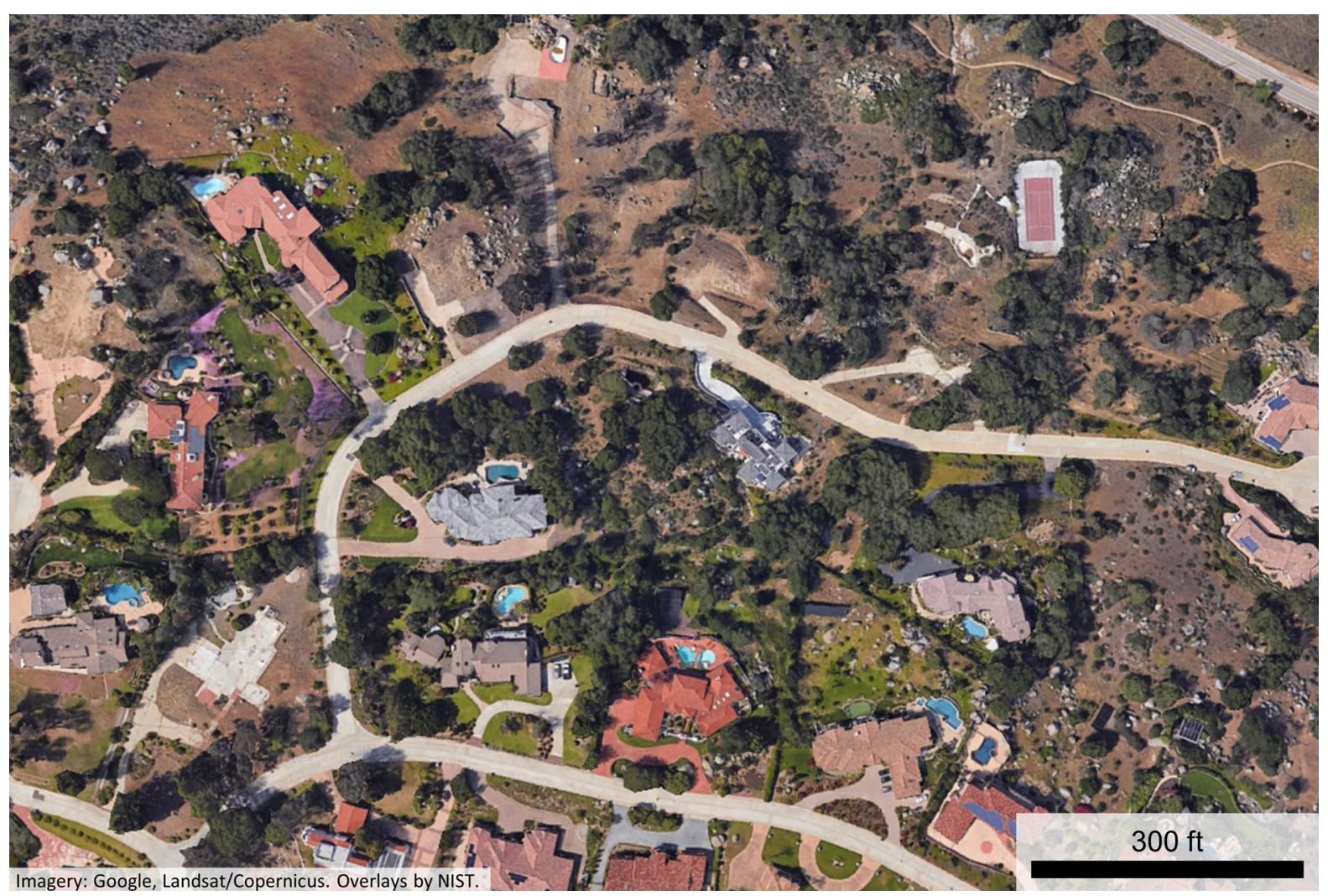

Figure 5. WUI Type 6: Low Density Intermix, The Trails, Rancho Bernardo, CA. Note irrigated lawns, long paved driveways, pools and tennis courts. Some structure-to-structure distances are representative of Moderate Density Intermix (lower part of image). Also note limited high density non-irrigated vegetative loading. 

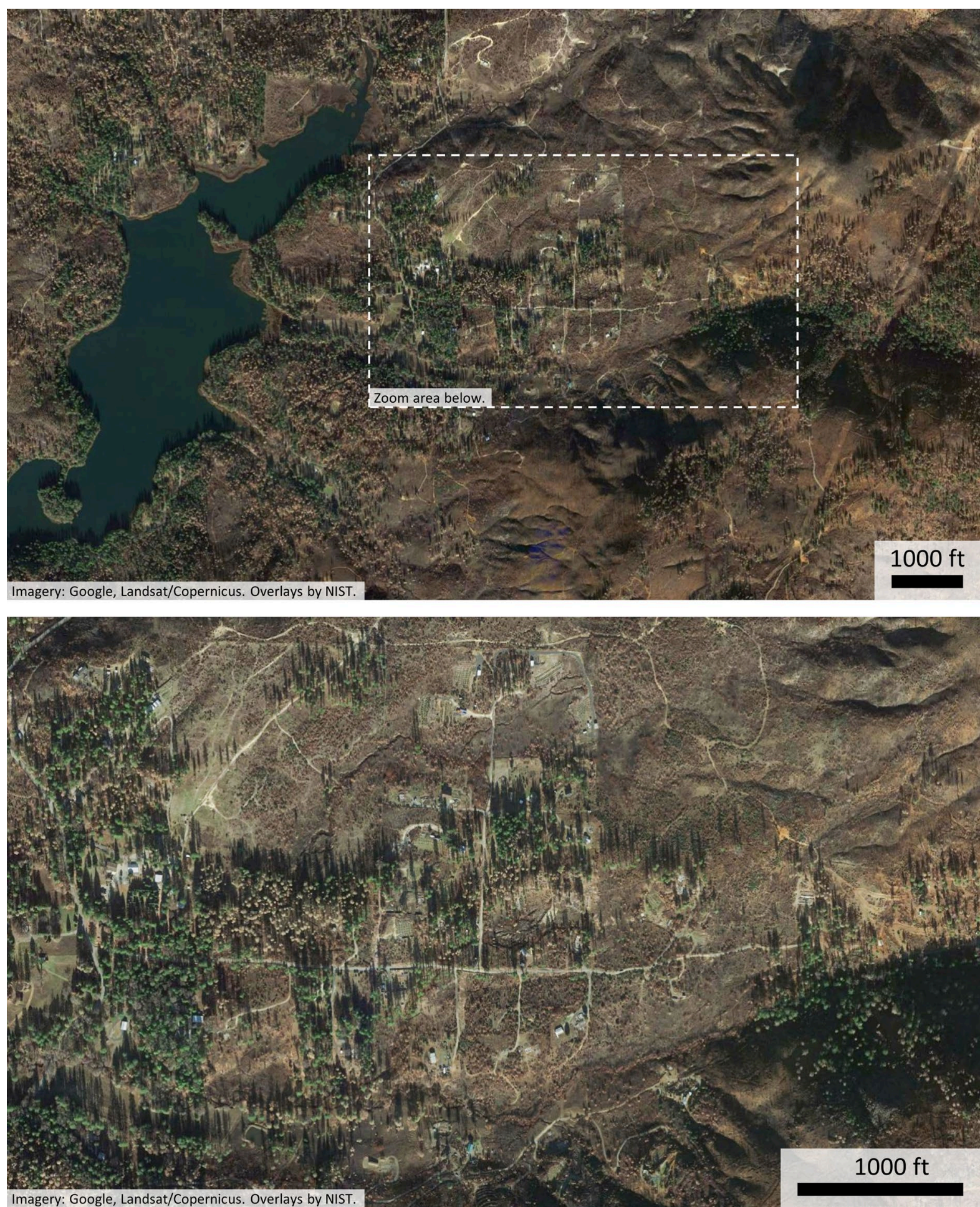

Imagery: Google, Landsat/Copernicus. Overlays by NIST.

Figure 6. WUI Type 6: Low Density Intermix: Concow, CA. Note the overall large SSD and structures located within the wildland vegetation. Note the imagery is taken after the 2018 Camp Fire. 
The seven WUI types described above can be used to help characterize WUI communities. These definitions are intended to provide general structure spacing information for a community or part of a community. The hazard mitigation and retrofit guidance provided in this document is parcel-centric and specifically accounts for local fuel spacing conditions. SSD and vegetation type, quantity, and location also relate to potential fire exposure. Exposures in the WUI are a combination of two components-fire and embers. These two exposure types are further discussed in Section 4.2. The impacts of fuel densities on exposures are discussed in Section 4.3, and the mitigation methodology to address the varying fire and ember exposures is described in Section 5. 


\section{WUI Hazard Mitigation Methodology}

\subsection{Introduction}

The proposed methodology was developed to meet two primary objectives:

1. Reduce structural losses in WUI fires by hardening structures and parcels, and

2. Prioritize mitigation efforts to reduce overall mitigation costs.

WUI fire hazard mitigation is often thought of as either an "every little bit helps" or a "onesize-fits-all" voluntary endeavor. The first approach is a good start and can provide realized benefits in low-exposure conditions where defensive actions ${ }^{5}$ are also very effective $[4,32]$. However, such an approach often leaves significant gaps and a false sense of security (see Sections 5.4.2 and 5.4.3 on partial compliance). This approach has significant shortcomings in conditions where defensive actions are not possible due to high exposures or limited resources. There is a fundamental difference in communication for public awareness and hardening for standalone protection. Public education is a critical component of a hazard communication strategy but does not go far enough to solve the larger-scale problem. The second approach, "one-size-fits-all" mitigation, is very expensive if all vulnerabilities are to be addressed. The goal of the methodology developed in this document is to bridge the gap through selective hardening actions in response to potential exposures at the parcel level, while considering exposures to/from neighboring parcels. This quasi-performance-based design approach can reduce the overall burden of mitigation in both effort and expense.

The mitigation strategy outlined in this document was primarily developed to address the needs for retrofit hardening of existing communities; however, the information can also be used for the design and construction of new communities. The proposed methodology is designed to augment defensible space [33]. The strategy relies on defensible space principles specifically related to the removal and maintenance of vegetative fuel and other combustible materials. The strategy was developed over a period of 16 months through a collaborative effort between NIST, CAL FIRE, and IBHS and leverages the most current science and data together with more than ten thousand hours of pre- and post-WUI fire field data collection conducted by the collaborating agencies. Discussions with the building industry were necessary to clarify and improve different implementations for retrofit solutions. The HMM will continue to be adapted and revised as additional science and technical findings become available.

Structures in the WUI can experience two different types of hazardous exposures - embers and fire (i.e., flames via radiation and/or convection) [34]. To survive without contributions of defensive actions (see Section 5.4.1 on the impact of defensive actions in the WUI) structures must be able to withstand both ember and fire exposures. This adaptive methodology is designed to harden the structure and the parcel against both hazards.

\footnotetext{
${ }^{5}$ Defensive actions include fuel displacement, fire suppression, fire containment, and exposure protection by first responders.
} 
There is a direct relationship between exposure and the structure hardening required for survival, and effective mitigation is a tuned balance of the two components. This relationship is illustrated in Figure 7, where the two knobs or dials represent exposure level and structure hardening. There are as many relationships that will result in structure ignition as there are relationships or settings that will result in no ignition. At the extreme, if the exposures (both fire and embers) are eliminated then no hardening is required. Conversely, if a structure is hardened to a windowless concrete bunker, it could survive an extreme exposure. It is acknowledged that the bunker approach is not realistically implementable or desirable, highlighting the need for a balanced strategy between exposure reduction and structure hardening.

- Remove Fuels

- Reduce Fuels

- Relocate Fuels

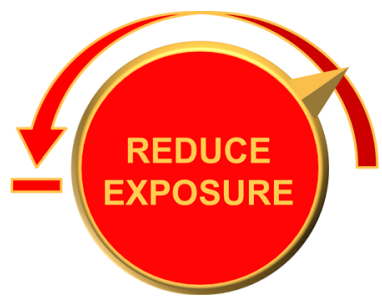

Figure 7. WUI fire hazard mitigation is a balance between two input dials-reducing exposure and increasing structure hardening.

\subsection{Quantifying Ember and Fire Exposures}

\subsubsection{Embers}

In a WUI fire, structures will likely experience ember exposures. Embers can cause direct ignitions of structures and parcels. Ignitions of parcel-level features may result in fire exposures to the structure and generation of additional embers. Structure ignition will depend on the vulnerabilities present on the structure and the intensity/duration ${ }^{6}$ of local ember exposures.

Ember exposures can vary over several orders of magnitude in number flux (count $/ \mathrm{m}^{2} / \mathrm{s}$ ) and in energy content, as embers can range from sub-millimeter scale to many centimeters in size $[4,35,36]$. In WUI fire events the initial embers arriving to a structure often originate from beyond the parcel that is being protected/hardened. Depending on the origin of the embers and the ownership of the ember generating fuels, options may be available to limit ember generation. While ember exposures can be reduced locally by defensive actions, the presence of first responders cannot be relied upon particularly during large incidents. Therefore, structures must be hardened to withstand various ember exposures ranging from very low to very high. Because the exposure intensity and duration cannot be controlled, or in many cases even predicted, ember hardening must address significant ember exposures and

\footnotetext{
${ }^{6}$ Intensity of ember exposures will be a function of several factors including size distribution, number density, and energy content, which all vary in both space and time.
} 
associated local ember accumulations. While scientific work is in progress to measure and quantify ember fluxes (e.g., [37-39]), visual observations and ignition occurrences are the best documentation at this time. The technical goal is to prevent ignition, not merely delay it. This is accomplished through the use of noncombustible materials in vulnerable areas of the structure. A detailed list of ember hardening requirements is discussed in Appendix A.

On the parcel, embers can cause the ignition of different parcel-level features. The hardening of these features can fall outside the current regulatory practices of fire departments and local AHJs. One example is recreational vehicles (RVs). The ignition resistance of RVs to embers will impact the potential contributions of RVs to fire spread within and across parcels in the WUI. RVs and other parcel-level features will generate both ember and fire exposures.

\subsubsection{Fire}

Fire exposures can originate from within the respective parcel or from adjacent parcels or wildlands. Like ember exposures, fire exposures can vary in intensity and duration. However, unlike embers that can travel several miles, fire exposures impact potential fuel in the range of tens of feet, as radiation and convection decay rapidly with distance.

There is a significant connection to be made between fire exposure and hardening. A structure with limited hardening can tolerate a low fire exposure relatively easily. Examples of low fire exposures are a mulch fire or a shrub fire. While these exposures can generate heat fluxes of $15 \mathrm{~kW} / \mathrm{m}^{2}$ locally, these exposures are very limited in space and have short finite durations. These types of low exposures are not a challenge to hardened structure cladding (e.g., stucco, cementitious board) and do not cause cladding failure as current test methods (e.g., ASTM E2957) are designed to accommodate them. While non-threatening to hardened structure cladding, these exposures can still pose a significant ignition hazard to other non-hardened exposed combustibles, which may further increase the total exposure to the structure. Depending on materials and assembly construction, a low fire exposure can result in local ignition and subsequent structure loss.

Hardening for these types of exposures requires localized changes in building cladding and reinforcement of the assembly. As an example, raising the combustible cladding from the ground $^{7}$ uncouples potential exposures from a mulch bed or an accumulation of wind-blown flammable materials (e.g., pine needles and leaf litter). This strategy is easier and more cost effective to implement than replacing the entire siding for that very targeted low intensity fire exposure. It should be noted that while low intensity fire exposures can be treated with local hardening solutions of exposure uncoupling (e.g., fuel displacement) or structure hardening, they must be addressed if structure survivability is to be achieved.

Fire exposures are a continuum in both intensity and duration. The above example illustrates the low end of that continuum. An example at the other end of the fire exposure spectrum

\footnotetext{
${ }^{7}$ Table A, item 10, in Appendix A requires a noncombustible cladding for the first $2 \mathrm{ft}$ from ground level. Field observations frequently identify wind-blown debris piles exceeding $1 \mathrm{ft}$ in height.
} 
may be encountered in a high-density construction environment where structures are separated by $6 \mathrm{ft}$ (i.e., $3 \mathrm{ft}$ setback from property line). A fully involved residential structure will expose the neighboring residence to very high heat fluxes for a prolonged duration. High-exposure fires can also be generated by auxiliary structures. Such high heat fluxes will challenge almost all typical residential construction. A structure that can withstand these types of exposures can be thought of as built like an inside-out furnace. While this is technically achievable with current construction materials, this level of hardening is very difficult to retrofit existing construction.

It should be noted that wildland vegetation at the edge of an interface community can also generate very high heat fluxes with very long flame lengths (much longer than what is generated from a residential structure). These wildland fire heat fluxes can be very large and easily result in structure ignition even if they are not as long lived as fluxes from a fully involved residence. These impacts can be further accentuated in the presence of complex terrain (i.e., slope, aspect, canyons).

In between these two fire exposure extremes are scenarios where hardening the cladding of the primary residence will provide increased resilience and significantly reduce or eliminate the structure's ignition potential. This is further described in Section 5.2.

The primary technical approach to dealing with the fire exposure problem is to uncouple the exposure by implementing fuel displacement (e.g., moving firewood away from other combustibles) or fuel removal (e.g., remove a shed from a property) if space is not available for fuel displacement.

\subsection{Structure Ignition Pathways}

There are multiple structure ignition pathways from both ember and fire exposures in the WUI $[4,5,7,34,40]$. Figure 8 illustrates the parcel-level combustible features that can contribute to fire spread within a parcel as well as across parcels. The list is not all-inclusive but is used here to illustrate the potentially large number of combustibles. Fire can move across one or multiple combustible features (becoming new sources of fire and embers) and across multiple parcels. The NIST Camp Fire Case Study [7] showed 16 different pathways that resulted in structure ignitions during that event.

The ignitability and energy release (in terms of both embers and fire) of these combustible features is a function of materials, assembly and design particulars, and size. Of the features in Figure 8, only firewood (wood piles), vegetation, and mulch have inherent combustible characteristics. To some extent, all of the other features can either be made of, or utilize cladding of, noncombustible materials. This is readily achievable for simply assembled features like fences but is significantly harder or impossible to achieve for complex fuels like RVs and other vehicles (e.g., cars and boats). 


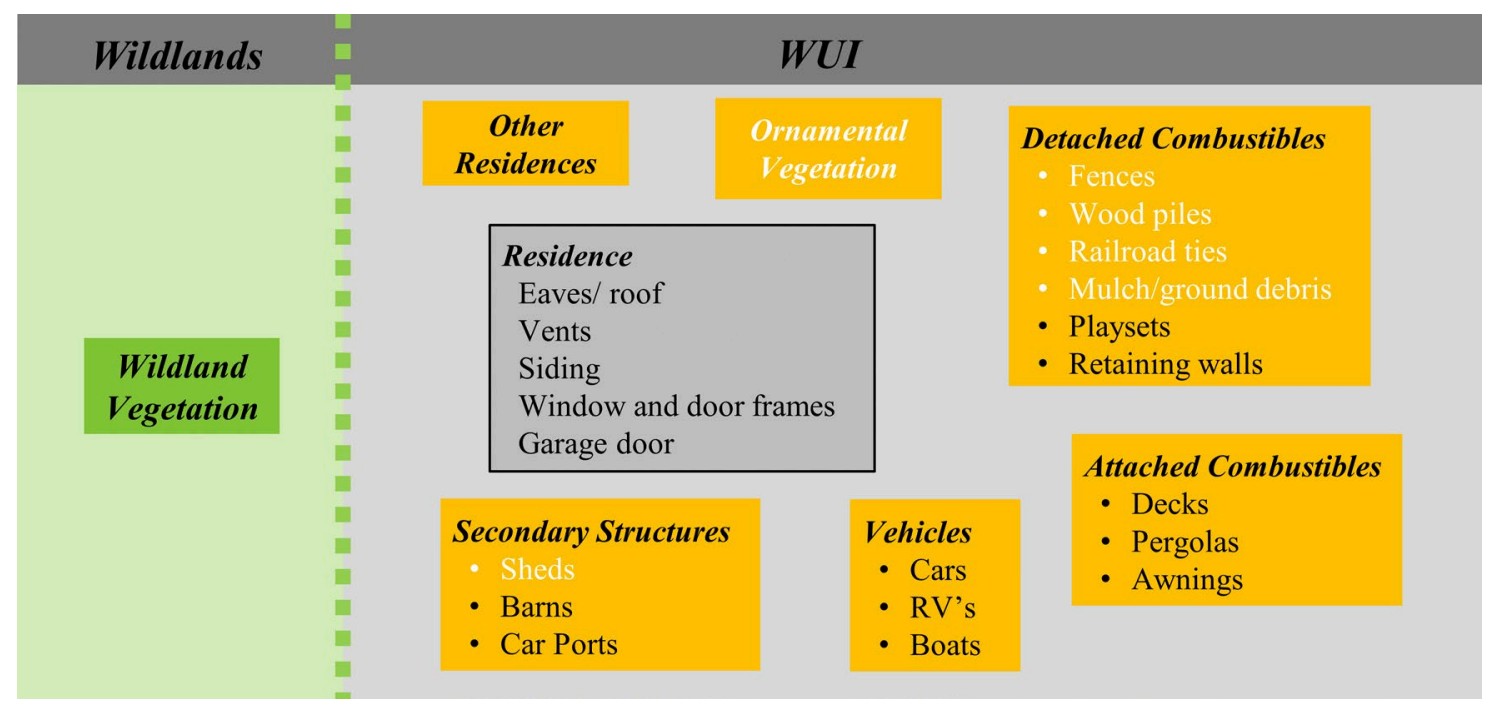

Figure 8. Parcel-level combustible features that can contribute to various structure ignition pathways. Highlighted in white are hazards that NIST and IBHS have performed extensive study of.

There are three technically important considerations when assessing fire spread within and across parcels. These are that:

1. parcel boundaries typically limit the continuity of protection between parcels,

2. linear features ${ }^{8}$ can carry fire very efficiently within and between parcels, and

3. fuel agglomeration has significant impact on energy release and fire spread.

\subsubsection{Impact of Parcel Boundaries on Code Application}

Historically, codes have been parcel-centric and address exposures in the context of protecting a residence from the exposures on the same parcel. An example of how code compliance is typically interpreted/applied is illustrated in Figure 9, which shows a diagram of the placement of an auxiliary structure (e.g., a shed). Codes provide a minimum separation distance requirement for auxiliary structures. In some cases, the code requirement places the auxiliary structure at a minimum distance from the residential structure $(30 \mathrm{ft})$, however, it provides very little for the protection of structures in adjacent parcels as the auxiliary structure setback from the property line does not reflect the potential hazard to adjacent parcels. A $5 \mathrm{ft}$ setback is often allowed if the auxiliary structure is not sprinklered, placing the auxiliary structure as close as $10 \mathrm{ft}$ from a non-sprinklered residence on the other side of the property line, seen in Figure 9a. Both structures are protected by the necessary SSD when the two residences are located on the same lot, as in Scenario B. When property lines are considered as a limit of code application, the hazard imposed from the auxiliary structure to the neighboring residence in Scenario A is unmitigated.

\footnotetext{
${ }^{8}$ combustible features such as fences, retaining walls, and landscaping railroad ties
} 


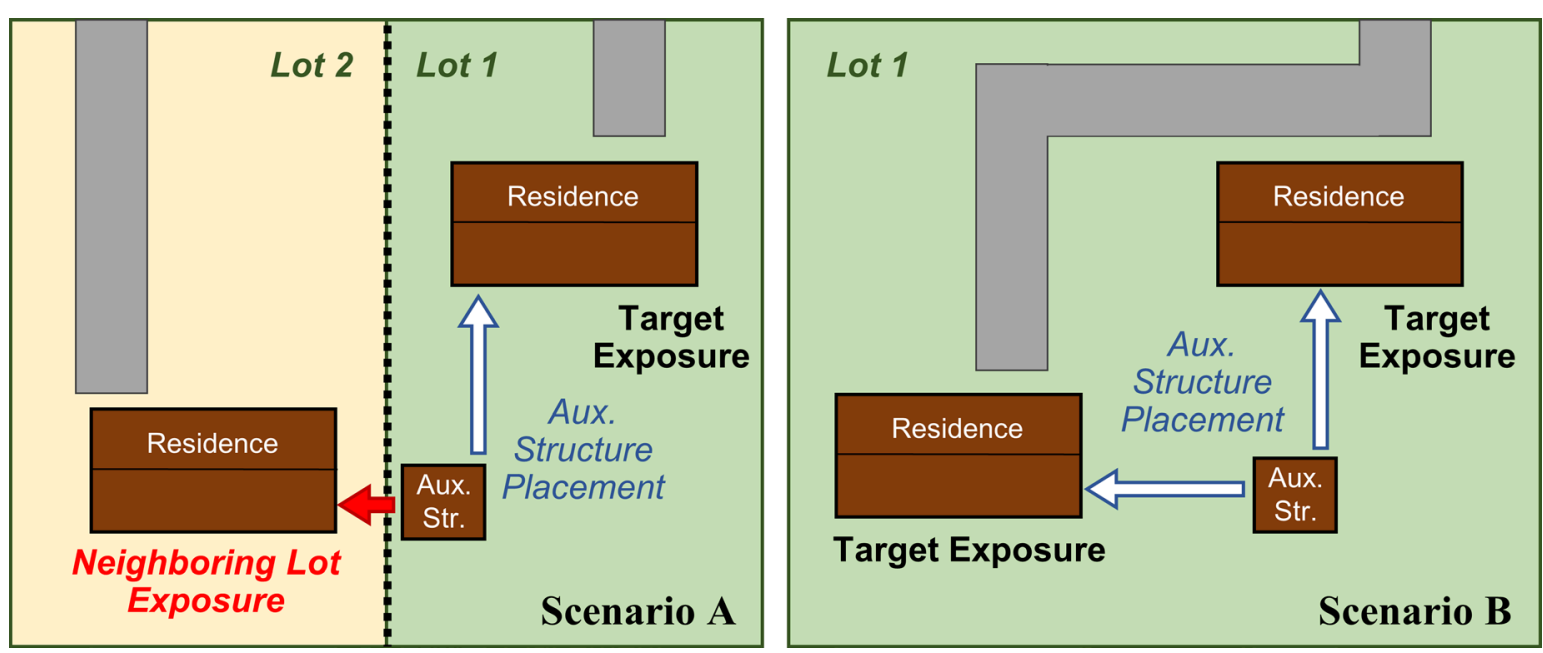

Figure 9. Existing codes are parcel centric. Residential structures are similarly located in Scenario A and B; however, the parcel division in Scenario A allows placement of an auxiliary structure too close to the neighboring primary structure when the parcels are considered independently.

\subsubsection{Impact of Linear Features on Fire Spread}

The impact of linear features was first documented in the Witch/Guejito Case Study [8, 32] and quantified during the Amarillo Case Study $[5,6]$. This was further observed during the Waldo Fire Case Study [4]. Based on these field observations, NIST has conducted over 100 experiments to assess fire spread among fences and the impact of fences on fire propagation [41].

Figure 10 illustrates how fire can burn along linear features to spread from a single ignition point to multiple lots and impact multiple residences. For example, following ignition and fire spread pathway $B$ shows that a single ignition on a fence line can carry fire to 6 lots and destroy (directly or indirectly) 3 residences depicted within the extent of the figure. It is also important to note that even with a partial improvement, such as removing the fence's direct connection to Residence 3, the result is still 2 destroyed residences within the figure:

Ignition B $\rightarrow$ shed $\rightarrow$ Structure $3 \rightarrow$ Structure 4 . 


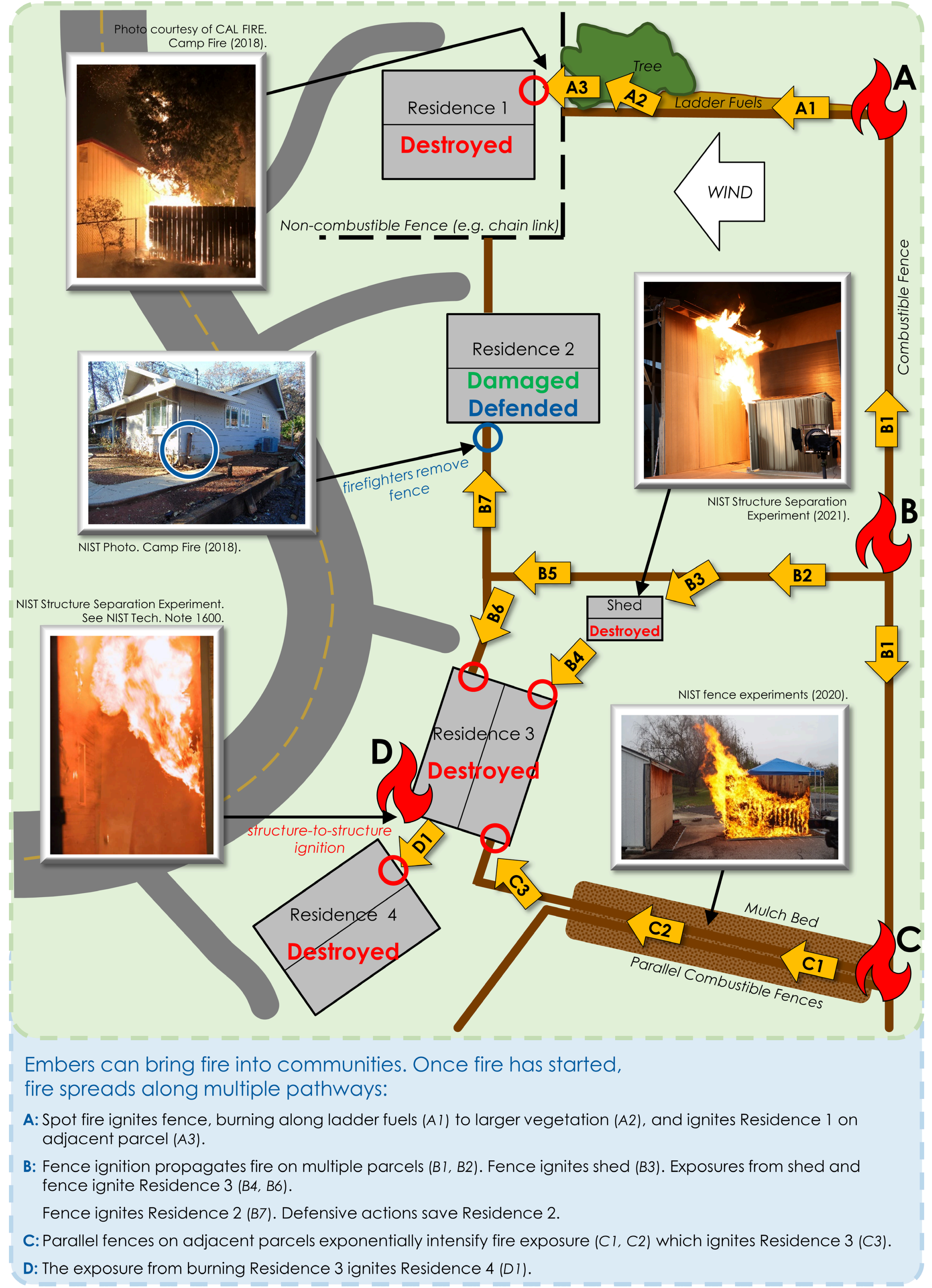

Figure 10. Illustration of numerous fire spread pathways among neighboring parcels via linear features and other combustibles. Inset photographs are from field observations and experiments. 


\subsubsection{Impact of Fuel Agglomeration on Fire Spread}

NIST experiments [41] have confirmed field fire observations about the role of fuel agglomeration on fire and ember exposures generated from combustibles in close proximity to one another. Figure 11 illustrates the intense burning and significant energy release from two fences placed 8 in $(20 \mathrm{~cm})$ apart. The observed increase in intensity compared to the burning of a single fence remained even when fences were spaced by 36 in $(92 \mathrm{~cm})$.
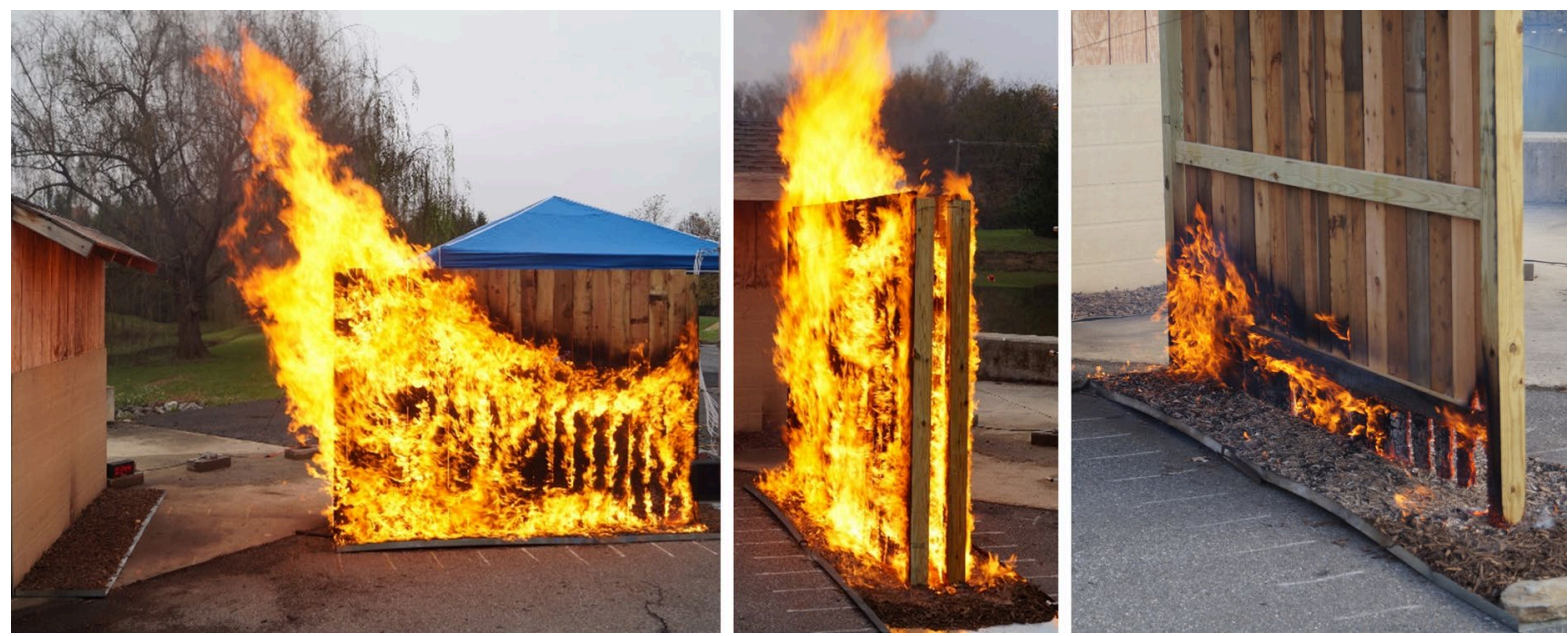

Figure 11. Parallel western red cedar fences burning with an applied wind of $13 \mathrm{mi} / \mathrm{h}(6 \mathrm{~m} / \mathrm{s})$ (left two images) compared to a single burning fence (right).

The impact of this increase in fire intensity on structure ignitions in the WUI is explicitly addressed in the methodology outlined here by requiring spacing between combustibles. This strategy decreases exposures to the asset to be protected (i.e., residence or other WUI feature), increases life safety of the public during evacuation, and creates a more defensible space for first responders to conduct rescue and firefighting operations.

Fuel agglomeration can occur unintentionally, as in the case of two neighbors putting up fences, significantly increasing the fire and exposure potential (see Ignition $C$ in Figure 10). However, another path to fuel agglomeration has been observed to be an indirect result of mitigation guidance to WUI residents - when fuel relocation is encouraged rather than fuel removal. This becomes a significant fire hazard in moderate- and high-density construction on medium to small parcels ranging from 1 ac down to 0.2 ac or less. One observed example is firewood piles moved as far away from the residence as possible to the edge of these small properties, typically near combustible fences, creating high energy pathways for fire to move through these high-density communities. Fuel relocation is a valid hazard reduction approach; however, it should not be used as the default approach on small parcels. This approach is better suited to larger lots that can adequately separate all combustibles. 


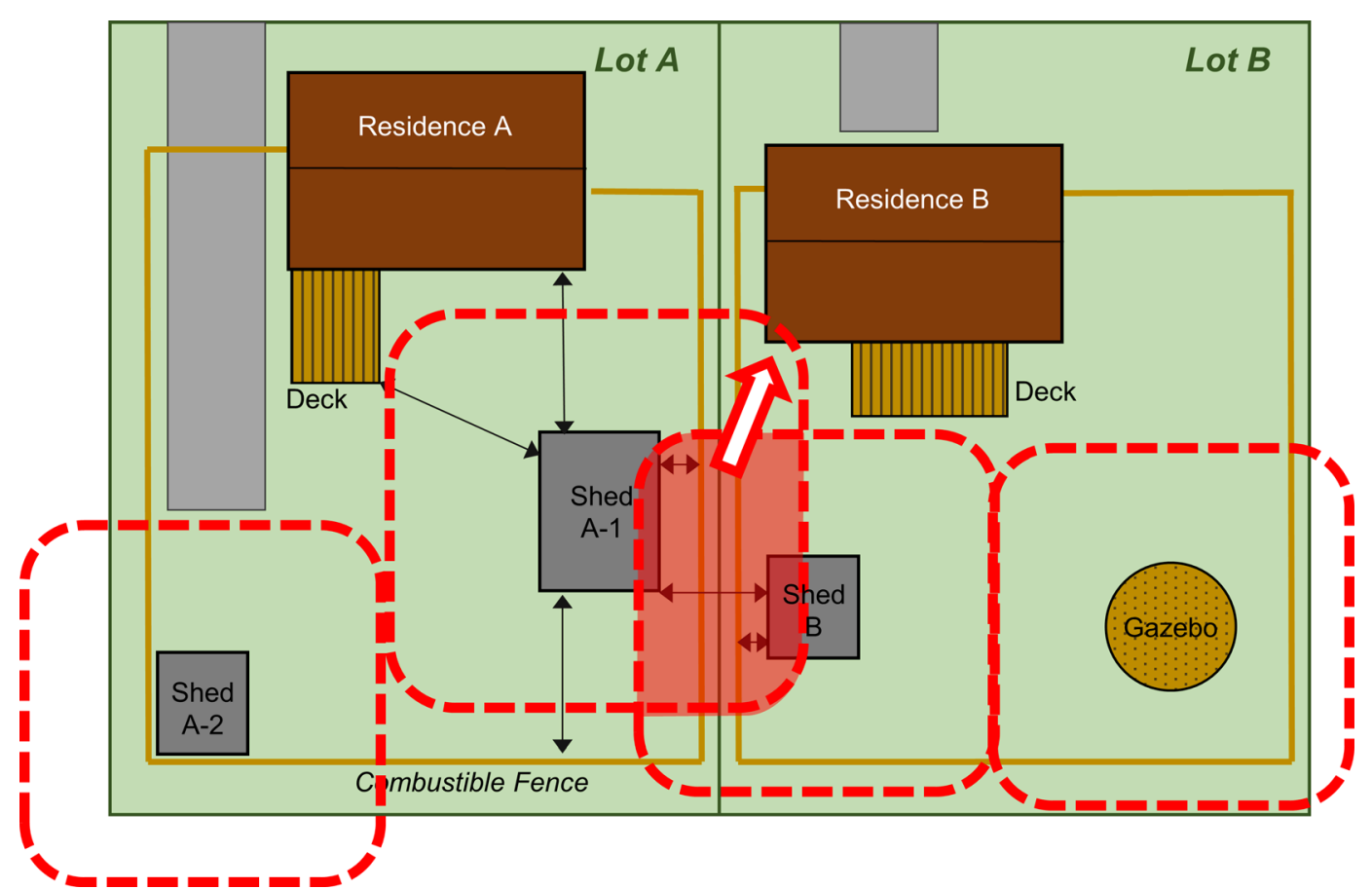

Figure 12. Spatial relationships between fuels on two adjacent parcels. Sheds are spaced appropriately from the residences and other fuels, except fences, on their respective lots. However, Shed $A-1$ is too close to Residence $B$, and both sheds act as an agglomerated fuel package along the property border. The sheds and fences will substantially increase the exposures from the red highlighted area, igniting the structures.

Figure 12 illustrates how the issue of fuel agglomeration and increased exposures is particularly important in high- and moderate-density construction. The two red dashed outlines represent areas of high fire exposure potential from the sheds and illustrate the challenge from the fire exposures of high fuel loading on small parcels. The area represented by the overlapping dashed outlines represents an area of potential high energy release, and the red/white arrow illustrates the direct impact from this high energy release to the primary residence. Backyards like those illustrated in Figure 12 represent a significant defensible space challenge to first responders. The highlighted example of the interactions between the two sheds ${ }^{9}$ and the combustible fences is one of several possible similar scenarios in Lots $A$ and $B$ in Figure 12.

Fuel agglomeration can present fire spread challenges even if the fuel spacing on individual parcels is adequate to prevent fire spread within the parcel. Figure 13 illustrates a scenario where the gazebo on Lot B (right) is located sufficiently far from the primary residential structure. However, agglomeration on the edge of the lot increases the fire spread hazard. Combined with the linear fence feature, a fire spread pathway to the neighboring parcel exists, even in this case where both structures have noncombustible fence attachments to the

\footnotetext{
${ }^{9}$ Note: smaller sheds (e.g., under $120 \mathrm{ft}^{2}$ in CA) are typically not as spatially regulated in terms of their placement as larger sheds. Current codes often allow these smaller sheds to be as close as $5 \mathrm{ft}$ from a residence and/or property line.
} 
primary structure. Additional fuel agglomeration on Lot A presents a hazard to the primary residence, indicated by the red and white arrows. The inclusion of an RV is to illustrate how combustible components that do not require a building permit can impact fire spread. RV owners may consider spatial separation distances similar to those for auxiliary structures to mitigate exposures to other combustibles.

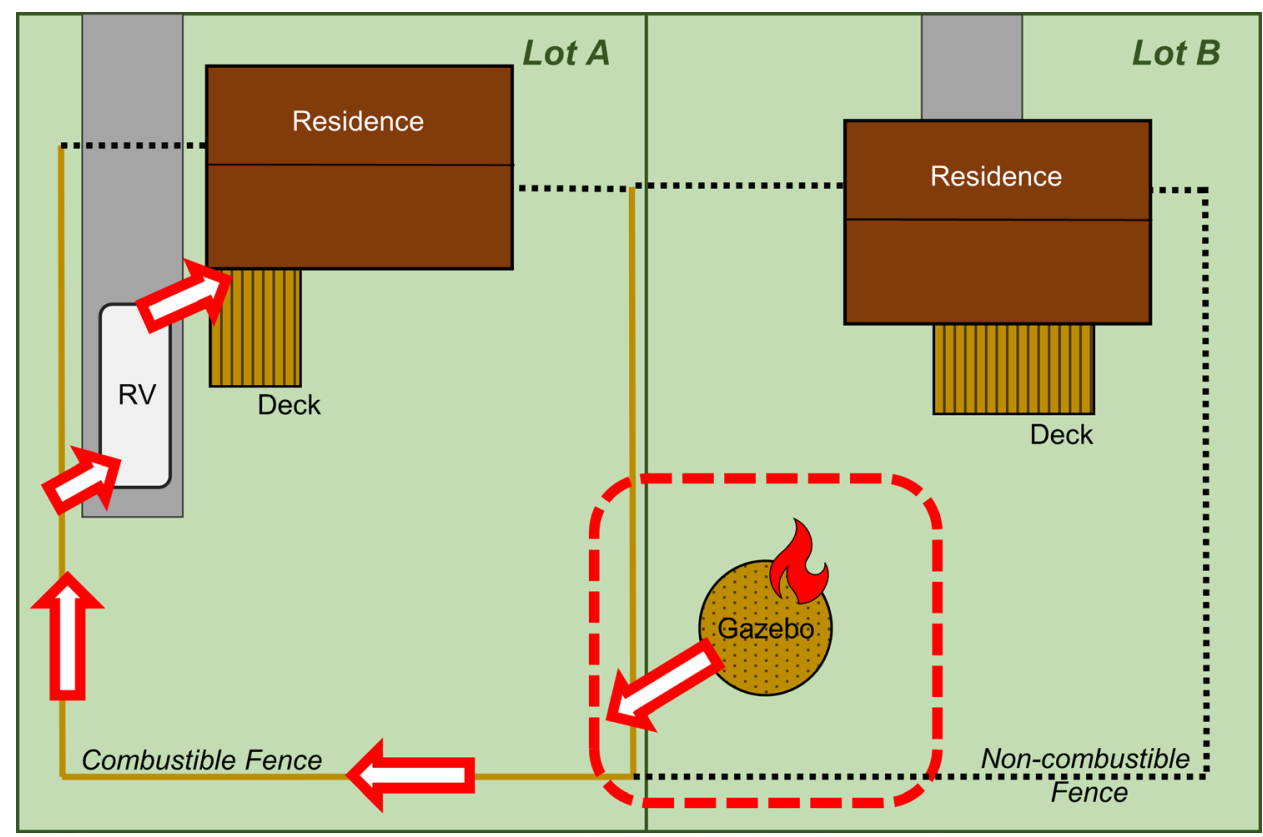

Figure 13. Fuel on Lot $B$ is adequately spaced from Residence $B$; however, fuel is agglomerated at the fence, which opens the pathway to Residence $A$. Ignition on Lot $B$ may still result in pathway shown, gazebo $\rightarrow$ fence $\rightarrow R V \rightarrow$ Residence $A$, despite noncombustible fence attachments on both residences.

Figure 14 depicts the agglomeration of residential structures and other fuels in a high-density community. This figure illustrates an actual WUI community and is drawn to scale. No fuel breaks are present through a community of hundreds of homes (extending beyond the illustrated parcels). Residential structures, with nominal SSD of $8 \mathrm{ft}$, and the parcel-level fuels including combustible fences, decks, sheds, and vehicles, can allow a single ignition to destroy significant portions of the community.

Spacing requirements to prevent direct high fire exposure to residences, together with the need to reduce overall high fire exposure conditions to enhance life safety, require a detailed spatial parcel-level fuel loading assessment. The methodology described in this report provides the tools to address this issue. The fuel/spatial relationships mentioned here are detailed in Table $\mathbf{B}$ and Table $\mathbf{C}$ in Appendix A. The impacts of non-compliance with spacing requirements on structure ignitions and community resilience will be addressed in Section 5.4.3. 


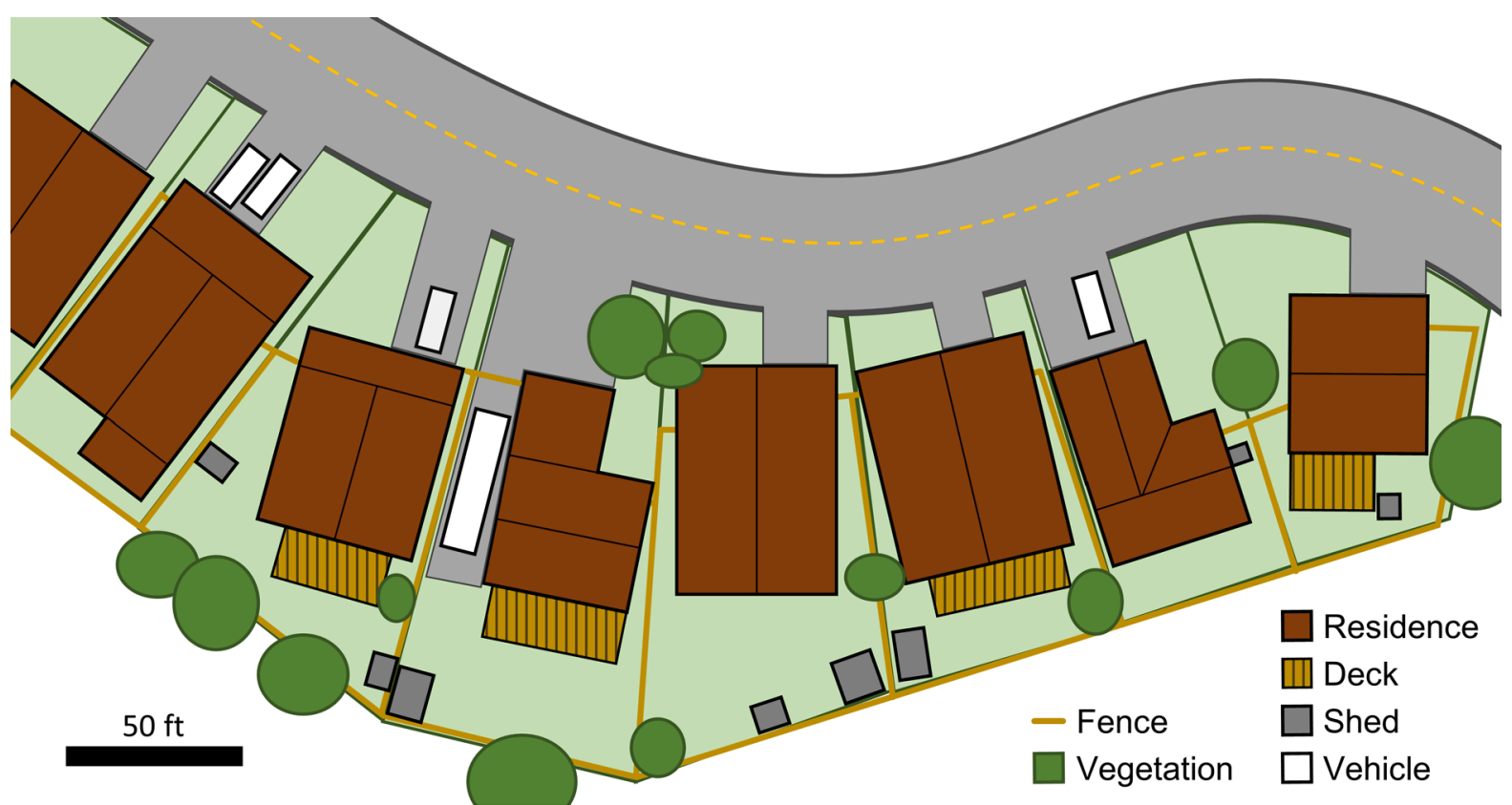

Figure 14. Illustration, based on an actual WUI community, showing real world fuel agglomeration and nominal $8 \mathrm{ft}$ SSD on high-density parcels. Illustrated conditions extend across the street and throughout the community (not pictured). Fuel continuity is present across the community of hundreds of homes. 


\section{Hazard Mitigation at the WUI}

The primary goal of the proposed structure and parcel hardening methodology is to minimize the chance of structure ignitions. The technical information presented here can be used for new construction; however, the methodology is focused on the retrofit of existing structures. In order to reduce overall retrofit costs, removal or displacement of fuels should be addressed first to reduce or eliminate the need for any structure hardening for fire. Factors influencing the effectiveness of the mitigation strategy are discussed in the following subsections.

A significant increase in structure ignition prevention is achieved by hardening structures against the complete range of expected exposures. This necessitates that all structures are hardened for high ember exposures. Ember showers are uncontrollable and often unpredictable because of airflow circulation patterns, unknown variability of primary wind direction, and ember characteristics. Hardening to prevent structure ignition from embers is achieved by addressing the multitude of known structure-level vulnerabilities. A total of 40 separate vulnerabilities have been identified along with associated mitigation actions. These vulnerabilities include the roof, gutters, windows, doors, vents, and attached combustibles. The full list of structure hardening requirements to prevent ignition from embers can be found in Table A in Appendix A.

A spatial analysis is necessary to identify potential exposures to the structure of interest. This consists of characterizing the extent of the potential exposure of the source and assessing its location with respect to the residential structure and other combustibles. If the placement has the potential to generate hazardous exposures, action must be taken to mitigate the exposure. This is accomplished by the approaches listed below:

a. Remove the fuel-this approach removes the exposure all together and is essential when there is limited space for fuel relocation/displacement.

b. Reduce the fuels - this approach reduces the number of combustibles and therefore the expected exposures.

c. Relocate the source - this approach allows the fuel to remain on the parcel but moves it away from the primary residence to reduce fire exposures.

d. Harden structures for fire exposure-if the above three approaches cannot be implemented, hardening the structure for fire will likely be necessary. The hardening option increases the likelihood of structure survivability but may not be as effective as hazard removal, and therefore, is the least desirable option. Additionally, hardening is typically the most expensive option.

The first approach of fuels removal (item a. above) is the most effective at hazard reduction and is the only implementable fuel reduction option on very small lots. Fuel removal works particularly well by replacing hazardous features with noncombustible alternatives, 
particularly when the combustibility of the feature does not add any functional component to its use. ${ }^{10}$ This approach is the most effective and can be used even on larger lots.

Reducing the quantity of fuels will directly reduce the exposures generated. The extent of exposure reduction will depend on the fuel type, fuel geometry, and local conditions. An example of fuel reduction would be keeping less firewood on the property.

Fuel relocation has been a key anchor of many hazard mitigation strategies. As discussed in Section 5.4.4, this is a valid approach for medium and large lots (medium and low housing density WUI). However, this approach can cause unanticipated problems when neighboring parcels are not considered in the hazard risk assessment, particularly on small lots.

Hardening for fire exposures may be necessary in certain spatial situations where fuel removal or displacement is not possible (e.g., primary residential structure spacing $25 \mathrm{ft}$ to $50 \mathrm{ft}$, see Table B Item \#1). The various components of structure hardening are presented in Appendix A (Table B and Table C) and must be evaluated for each structure. The potential effectiveness of structure hardening is dependent on the potential fire exposure from neighboring structures, wildlands, and other sources. Table 3 shows the effectiveness of hardening for fire in the various WUI Types.

The table illustrates that the effectiveness of hardening for fire is directly related to structure density. The coloring used in Table $\mathbf{3}$ is summarized for the following three structure density scenarios:

a. Low Density (SSD on the order of $>50 \mathrm{ft}$ ) - lower potential losses from individual structure ignitions, low potential for urban conflagration,

b. Moderate Density (SSD on the order of $25 \mathrm{ft}$ to $50 \mathrm{ft}$ ) - greatest impact on structure ignition resistance by hardening for fire exposures from neighboring structures, and

c. High Density (SSD on the order of $<25 \mathrm{ft}$ ) - must not have any structures ignite as risk of entire community loss is very high due to structure-to-structure fire spread.

The above strategy is based on field fire behavior observations as well as controlled laboratory and field fire experiments $[4,31]$. Fire behavior at the parcel level is very dynamic and, in a sense, very opportunistic, leveraging ignition vulnerabilities of different fuels and exposures between fuels. The above exposure/distance hardening strategy offers a path forward that creates discontinuities for fire exposures and selectively hardens structures where clear benefits can be achieved in ignition resistance.

The best available knowledge was utilized to determine the spacing distances to make the methodology implementable. As is the case with other guidance documents, ongoing research will continue refining the spacing guidance included here.

\footnotetext{
${ }^{10}$ Note: noncombustible features may not always provide identical aesthetics
} 
Table 3. Structure and parcel hardening effectiveness.

\begin{tabular}{|c|c|c|c|c|c|c|c|c|}
\hline \# & WUI Type & $\begin{array}{c}\text { Probability of } \\
\text { Structure } \\
\text { Survivability if } \\
\text { Neighboring } \\
\text { Structure Ignites }\end{array}$ & $\begin{array}{l}\text { Potential Fire }^{\mathrm{a}} \\
\text { Exposure from } \\
\text { Burning } \\
\text { Neighboring } \\
\text { Structure }\end{array}$ & $\begin{array}{c}\text { Exposure from } \\
\text { Other Parcel } \\
\text { Fuels }\end{array}$ & $\begin{array}{l}\text { Exposure }^{b} \\
\text { from } \\
\text { Wildlands }\end{array}$ & $\begin{array}{c}\text { Impact of } \\
\text { Structure Ignition } \\
\text { on Fire spread in } \\
\text { Community }\end{array}$ & $\begin{array}{c}\text { Likely } \\
\text { Effectiveness of } \\
\text { Partial Structure/ } \\
\text { Parcel Hardening }\end{array}$ & $\begin{array}{l}\text { Community/ } \\
\text { Neighborhood } \\
\text { Participation } \\
\end{array}$ \\
\hline 1 & $\begin{array}{l}\text { HD Interface - } \\
\text { Perimeter }\end{array}$ & Low & High & $f(\text { fuels, dist. })^{\mathrm{c}}$ & Variable & High & Low & Necessary \\
\hline 2 & $\begin{array}{l}\text { HD Interface - } \\
\text { Interior }\end{array}$ & Low & High & $f(\text { fuels, dist. })^{\mathrm{c}}$ & Low & High & Low & Necessary \\
\hline 3 & $\begin{array}{l}\text { MD Interface - } \\
\text { Perimeter }\end{array}$ & $f$ (hardening) & Moderate & $f(\text { fuels, dist. })^{\mathrm{e}}$ & Variable & Moderate & $\begin{array}{c}f \text { (wildland fuels, } \\
\text { parcel fuels) }\end{array}$ & Desired \\
\hline 4 & $\begin{array}{l}\text { MD Interface - } \\
\text { Interior }\end{array}$ & $f$ (hardening) & Moderate & $f(\text { fuels, dist. })^{\mathrm{e}}$ & Low & Moderate & $f(\text { parcel fuels })^{\mathrm{d}}$ & Desired \\
\hline 5 & MD Intermix & $f$ (hardening) & Moderate & $f(\text { fuels, dist. })^{\mathrm{e}}$ & Variable & Moderate & $\begin{array}{c}f \text { (wildland fuels, } \\
\text { parcel fuels) }\end{array}$ & Desired \\
\hline 6 & LD Interface & $f$ (hardening) & Low & $f(\text { fuels, dist. })^{\mathrm{e}}$ & Variable & Low $^{f}$ & $f$ (parcel fuels) & Desired \\
\hline 7 & LD Intermix & $f$ (hardening) & Low & $f(\text { fuels, dist. })^{\mathrm{e}}$ & Variable & Low $^{f}$ & $f$ (parcel fuels) & Desired \\
\hline $\mathrm{HD}=$ high density, $\mathrm{MD}=$ medium density, $\mathrm{LD}=$ low density & \multicolumn{8}{|c|}{$f(X)$ indicates "a function of $X$ " (e.g., the level of exposure from other parcel fuels is a function of the fuels and distance from the target structure) } \\
\hline \multicolumn{9}{|c|}{ a flames and radiation } \\
\hline \multicolumn{9}{|c|}{${ }^{\mathrm{c}}$ parcel-level mitigation will have limited impact if nearby upwind structures catch on fire } \\
\hline \multicolumn{9}{|c|}{$\mathrm{d}_{\text {would be a function of wildland fuel treatment AND hardening of most/all perimeter structures and parcels }}$} \\
\hline \multicolumn{9}{|c|}{ e parcel-level mitigation, including wildland fuel treatment, together with home hardening, will enhance structure ignition resistance } \\
\hline & nitions due to en & ers from burning re & ential structures $h$ & been observed a & as $200 \mathrm{ft}$ to & ft downwind & & \\
\hline
\end{tabular}




\subsection{Using the HMM}

The Hazard Mitigation Methodology (HMM) described in this report is summarized in four tables that can be found in Appendix A. The tables include all identified vulnerabilities; however, not all vulnerabilities may be present on every structure and/or parcel.

Communities and homeowners need to address all vulnerabilities present on each individual structure to enhance ignition resistance significantly.

Table A, in Appendix A, describes all 40 structure hardening actions that have been identified to date and that are needed to significantly reduce the ignition of structures from varying ember exposures. Table A contains information on the structure component, assembly, or attached combustible, the hardening action, the goal, and the applicable conditions (when that hardening action is needed). The table also contains notes and a relative cost column. Structural features with large surface area (e.g., other than Class A roof coverings) or interior corners can contribute disproportionately to ember accumulation and ignition, especially in low-ember exposure situations. Because of the variability in actual experienced ember exposures, all 40 actions must be addressed if a significant reduction in structure ignition probability is to be achieved. More details on partial use of the HMM are provided in Sections 5.4.2 and 5.4.3.

Fire exposures and reduction in structure ignitions from radiation and convection are addressed by three interconnected tables in Appendix A. Table $\mathbf{B}$ and Table $\mathbf{C}$ evaluate the spatial relationships of fuels on surrounding parcels and on the parcel where the structure of interest is being protected. Here the concept of Fuel Separation Range is used. This notion is described next in Section 5.2 and Figure 15 and Figure 16. Table $\mathbf{B}$ and Table $\mathbf{C}$ contain columns describing the fuel (hazard), minimum required fuel separation distance, the fuel separation range, the hardening action, notes, and whether the structure will need to be hardened against flames. Additional consideration may be needed when complex topography can result in higher exposures. The intent is to displace or remove the fuels to reduce or eliminate any structure hardening for fire in order to reduce overall retrofit costs. It should be noted that structure hardening is directional based on the expected exposures, and an allaround (full 360-degree) hardening is not required by default.

If any hardening is required by Table $\mathbf{B}$ or Table $\mathbf{C}$, the user is directed to Table $\mathbf{D}$ where structure hardening is explicitly addressed. Table $\mathbf{D}$ contains a list of 10 specific vulnerable structural components that need to be addressed to significantly reduce the ignition potential of the structure from radiative and/or convective exposures.

\subsection{Fuels Spacing}

Specific hardening needs for structure protection against fire are addressed through the relationship of the exposure intensity and distance between the exposure source and the residence. The rapid decrease in radiation and convection with distance is leveraged here to optimize the required level of structure hardening. To illustrate different structure hardening needs, three scenarios of a residential structure with different structure separation distance 
(SSD) to an auxiliary structure $>120 \mathrm{ft}^{2}$, and therefore different fire exposure levels, are shown in Figure 15 and described below. The term SSD is used in Figure 15 because both the source and the target are structures. The same concept applies for non-structure fuels, and in those cases the term fuel separation range (FSR) is used (Table B). Note that in all three scenarios the residence must also be fully hardened against ember exposures, regardless of the required fire hardening.
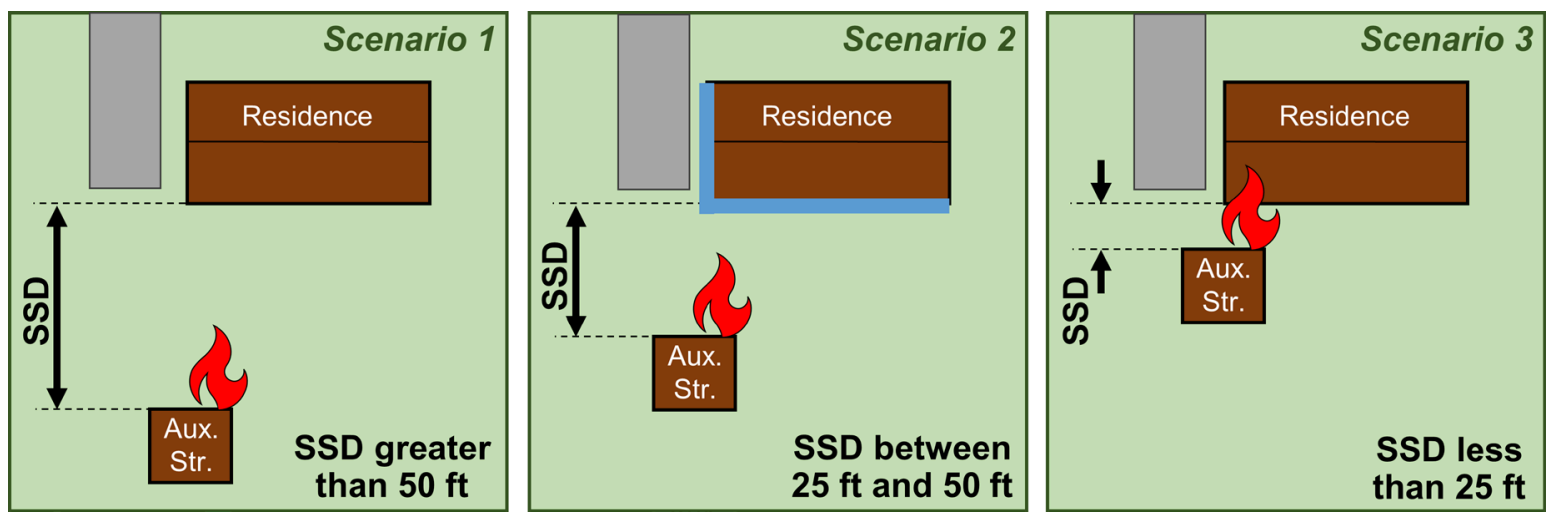

Figure 15. Three scenarios with a range of SSDs between the primary residence and auxiliary structure $>120 \mathrm{ft}^{2}:$ 1) greater than $50 \mathrm{ft}, 2$ ) between $25 \mathrm{ft}$ and $50 \mathrm{ft}$, and 3) under $25 \mathrm{ft}$. Structure hardening to increase ignition resistance is illustrated in blue (Scenario 2). Note that hardening is directional and is not necessarily required around the entire structure. Hardening for embers is required in all scenarios.

\section{Scenario 1}

This scenario represents exposure/distance combinations where the fire exposures do not reach the structure to be protected. A distance of $50 \mathrm{ft}$ or greater is used in this example of auxiliary structures with floor area greater than $120 \mathrm{ft}^{2}$ (Table $\mathbf{C}$ Item \#3). Based on field observations, the residence will not experience significant fire exposures at this distance (radiation and convection) and no hardening for fire is required.

\section{Scenario 2}

This scenario represents exposure/distance combinations where the fire exposures can ignite a structure. Hardening the residence can significantly mitigate the likelihood of structure ignition. Another way to say this is that there is a "sweet spot" in the spacing between the source and the target (residential structure or other asset to be protected) where hardening will add value. To follow the example of the auxiliary structure in Scenario 1, this range in spacing is when the auxiliary structure is between $25 \mathrm{ft}$ and $50 \mathrm{ft}$ from the target. This distance range is a function of the source's energy content and spatial configuration. In this case, hardening the auxiliary structure (the source) would also reduce its ignition potential, and consequently, exposure to the primary structure. 


\section{Scenario 3}

In many ways this is the most challenging scenario. This spacing range represents exposure/distance combinations where the very high fire exposures (e.g., direct flame contact from a fully involved residence) will ignite a structure and mitigation in the form of hardening will have limited or no effect in reducing the ignition potential of the structure. This represents scenarios with very high fuel densities. In the case of the auxiliary structure greater than $120 \mathrm{ft}^{2}$, this occurs when the auxiliary structure to target (residence or other asset to be protected) separation is less than $25 \mathrm{ft}$.

In this scenario, the path forward to increase the survivability (i.e., ignition resistance) of the target is to prevent the ignition of the source. For auxiliary structures this can be achieved by also applying the hazard mitigation methodology to the auxiliary structure. The best practice is to displace or remove the shed. Relying on ignition prevention of auxiliary structures enhances primary structure survivability under certain conditions, however, does not provide the same protection provided by displacement or removal.

The same approach applies to fire spread between residential structures and is illustrated in Figure 16. Unlike small auxiliary structures that can be removed or relocated in many cases, the spacing between existing residential structures is fixed and the applicable scenario will depend on the SSD. 

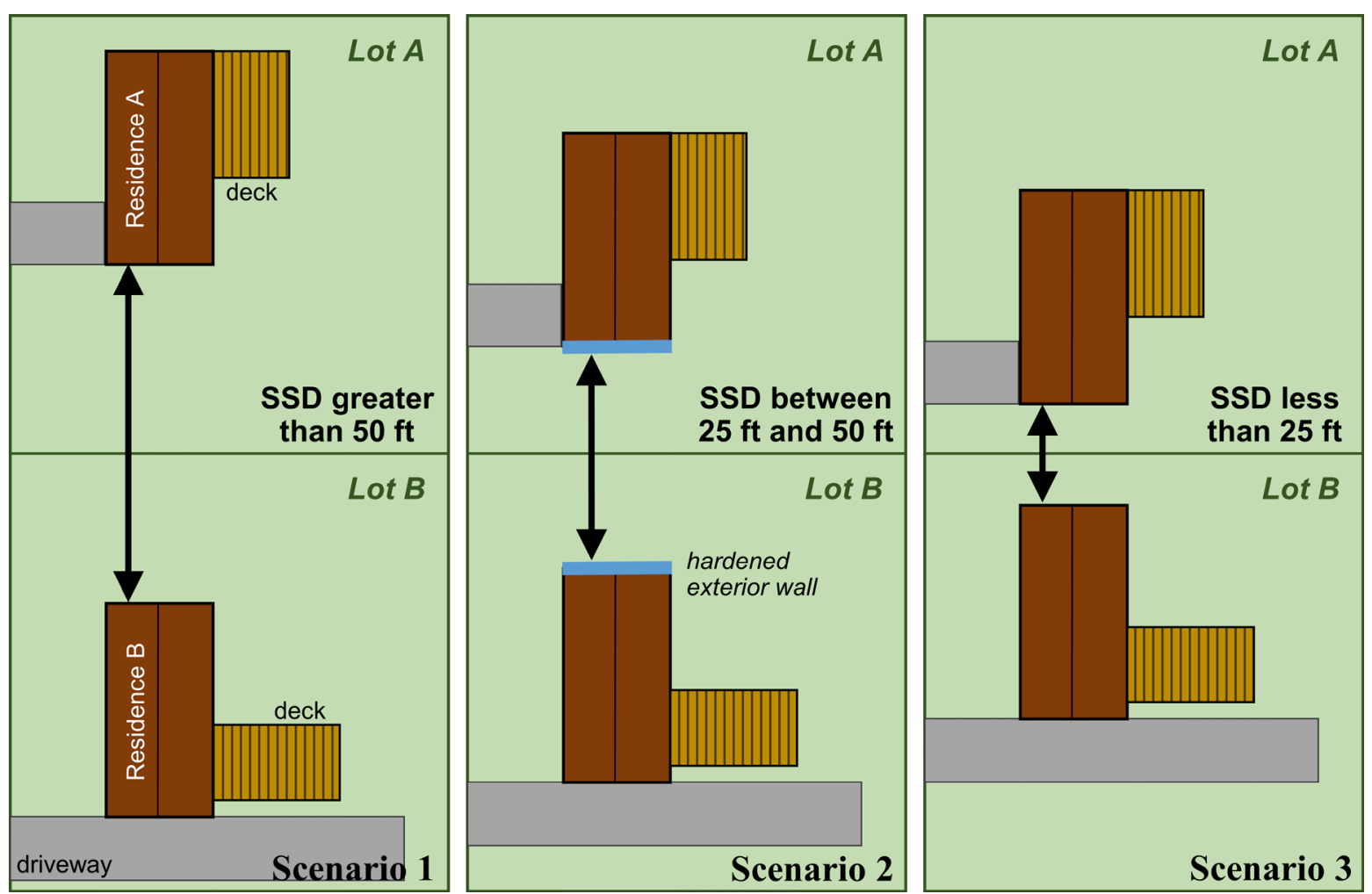

Figure 16. Three scenarios with a range of SSDs: 1) greater than $50 \mathrm{ft}, 2$ ) between $25 \mathrm{ft}$ and $50 \mathrm{ft}$, and 3) under $25 \mathrm{ft}$. Structure hardening to increase ignition resistance illustrated in blue (Scenario 2). Note that hardening is directional and is not required completely around both structures. Hardening for embers is required in all scenarios. 


\subsection{Fuel Density in Different WUI Types}

In Section 5.2 the fuel spacing concept was introduced. This section explores the implications of fuel spacing/density across multiple parcels and different WUI Types. WUI Types can be viewed macroscopically; however, assessments need to be conducted at the parcel level. There may be considerable variability between two parcels with the same WUI Type. Lot size alone is not sufficient to determine availability of space for combustible features. Residence placement, lot geometry, and structures on surrounding parcels will impact space availability for combustible features. This is illustrated in the following example scenarios listed in Table 4.

Table 4. Parcel layout and fuel placement in different WUI Types visualized in Figures 17 through 20.

\begin{tabular}{ccccccc}
\hline Scenario & $\begin{array}{c}\text { WUI } \\
\text { Type }\end{array}$ & SSD (ft) & $\begin{array}{c}\text { Lot Size } \\
(\mathrm{ac})\end{array}$ & $\begin{array}{c}\text { Lot } \\
\text { Dimensions } \\
(\mathrm{ft} \times \mathrm{ft})\end{array}$ & $\begin{array}{c}\text { Backyard } \\
\text { Size }(\mathrm{ac})\end{array}$ & $\begin{array}{c}\text { Backyard } \\
\text { Dimensions } \\
(\mathrm{ft} \times \mathrm{ft})\end{array}$ \\
\hline $\mathrm{A}$ & 2 & 10 & 0.14 & $110 \times 55$ & 0.06 & $55 \times 25$ \\
B & 4 & 41 to 55 & 0.45 & $150 \times 150$ & 0.14 & $150 \times 35$ \\
$\mathrm{C}$ & $6 / 4$ & 31 to 34 & 1 & $330 \times 130$ & 0.6 & $200 \times 130$ \\
$\mathrm{D}$ & 6 & $>50$ & 1 to 1.2 & variable & variable & variable \\
\hline
\end{tabular}

For SI: $1 \mathrm{ft}=0.305 \mathrm{~m}, 1 \mathrm{ac}=0.4$ ha

Compare SSDs for Scenario B (WUI Type 4) and Scenario C (Type 4 or Type 6). While SSDs for Scenario B are larger, the lots are smaller which is the exact opposite of Scenario C. Figure 17 through Figure 20 illustrate how much space may be available on individual parcels or between parcels from select locations in the WUI. The blue shapes in these figures represent general locations where high hazard combustibles such as sheds, RVs, gazebos, and other parcel-level auxiliary fuels may be placed without directly compromising the surrounding structures from radiative and convective fire exposures. The shapes are approximate and used for illustration purposes only; exact dimensions would be a function of the combustibles present. The actual placement of the combustibles to prevent structure ignition from fire can be determined using the tables in Appendix A.

Scenario A, in Figure 17, shows a high-density interface community with SSD of $10 \mathrm{ft}$ between residences. The area highlighted in red depicts the limited space available for auxiliary fuels in the backyard. In this scenario, the shed located in the highlighted area is closer to the neighboring residence $(20 \mathrm{ft}$ ) than the owner's residence $(27 \mathrm{ft})$. Additional hazards include the tight spacing of fences between residences, the shed placed against the fence, and interconnected fences joining multiple parcels. Conditions like this negatively impact defensible space, safe operation of first responders, and structure survivability. 
An example from a medium-density interface community (Type 4) is illustrated in Scenario B, Figure 18. However, within this community, locations may be classified as Type 5 due to increased wildland vegetation. This scenario illustrates the effect of structure placement (on residential lots) on the available space for auxiliary fuels. The red highlighted area between the two residences contains fuels that can result in high exposures to both parcels. The area contained by the blue outline is selected here to illustrate portions of the parcel where combustibles might be safely placed away from both residences. The connectivity of the two areas outlined in red increase the number of available fire spread pathways to both primary residences. The lower two figures depict the actual fire progression pathway (shed $\rightarrow$ fence $\rightarrow$ shed $\rightarrow$ house) between parcels which resulted in the destruction of the structure on the left even while defensive actions were taking place.

Larger lots, in Scenario C for example, are often found in lower density communities (Type 6) and typically have space to accommodate additional combustible fuels. However, structure positioning on the parcels can result in locally high structure densities with reduced SSD, reclassifying to WUI Type 4 or 5 (medium-density interface or intermix). An example is shown in Figure 19, where parcels have large backyards ( $0.6 \mathrm{ac})$ and the structures are placed well away from the wildland boundary. However, SSD is a key driver to fire propagation between residences and will require targeted hardening in the illustrated case. While the SSD in this scenario is greater than in high density communities, fuel placement between structures can still impact fire spread and defensive actions (fuel agglomeration effectively reducing SSD).

Scenario D (Figure 20) shows another case with large lots similar in size to Scenario C. However, structure placement towards the center of the lot increases the average SSD and creates auxiliary fuel zones, or areas within the community that are well away from all surrounding residential structures, highlighted by the blue outlines. Avoiding agglomeration of fuels within the outlined areas would influence the total number of auxiliary fuels allowed in these spaces. 

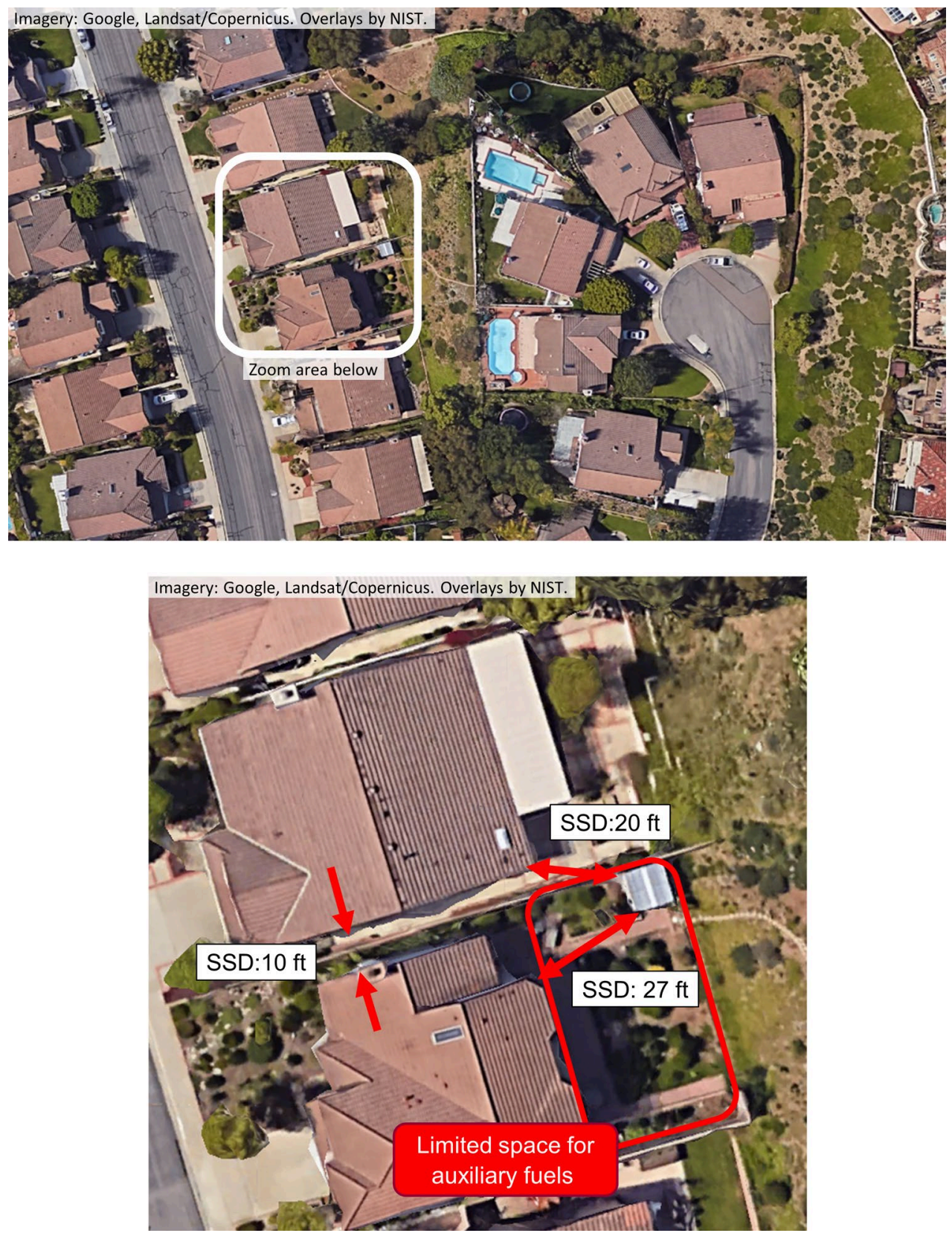

Figure 17. Scenario A, WUI Type 2. Small parcel with small SSD provides minimal space for auxiliary fuels. The shed is located closer to the neighboring residence than the owner's residence. 


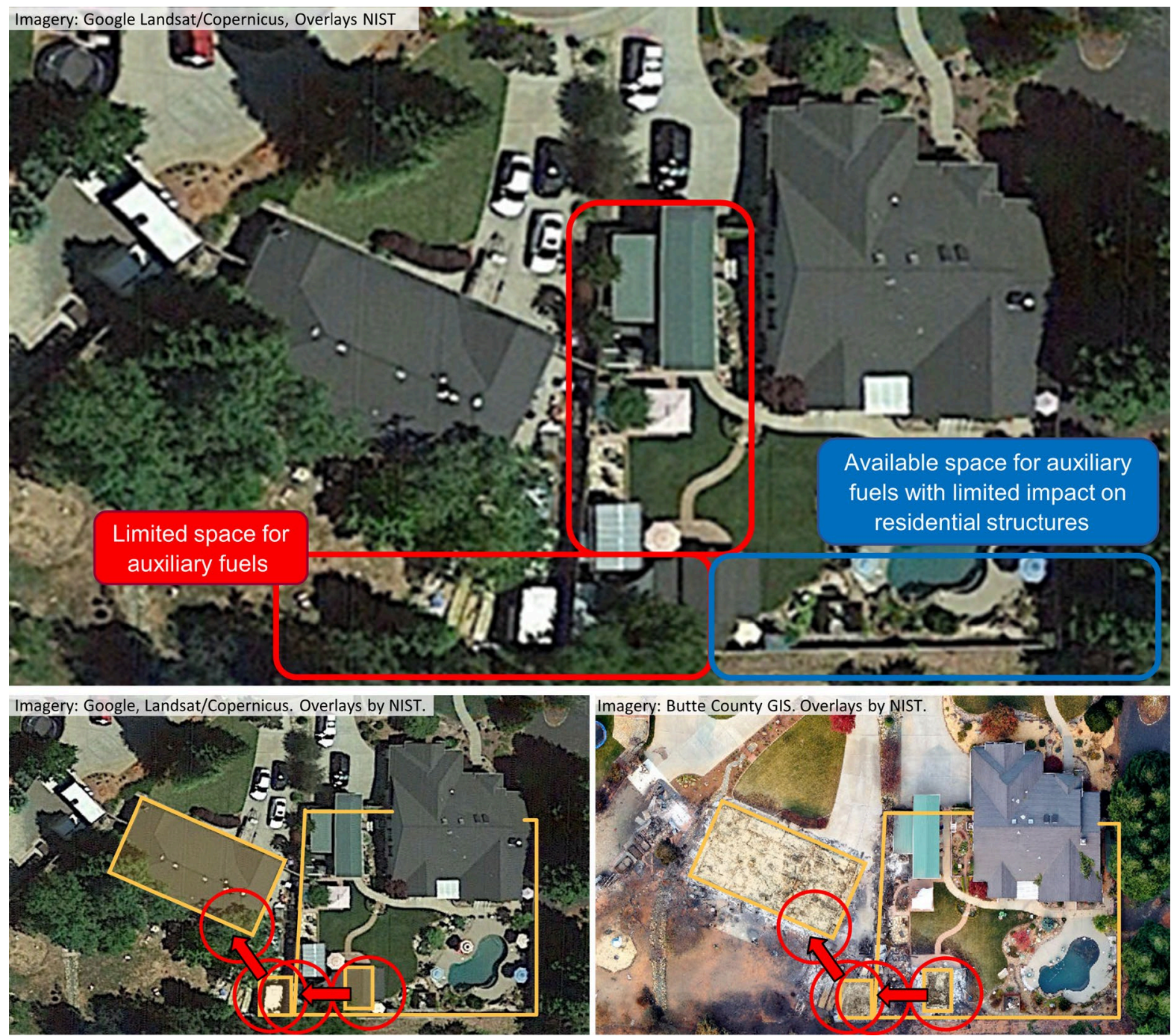

Figure 18. Scenario B, WUI Type 4. Moderate density interface. In some areas there is limited space for auxiliary fuels, shown by the agglomeration on the property boundaries (red highlights). The area highlighted in blue presents reduced impact on residential structures. The lower figures show before and after fire imagery with the actual fire spread pathway highlighted. 


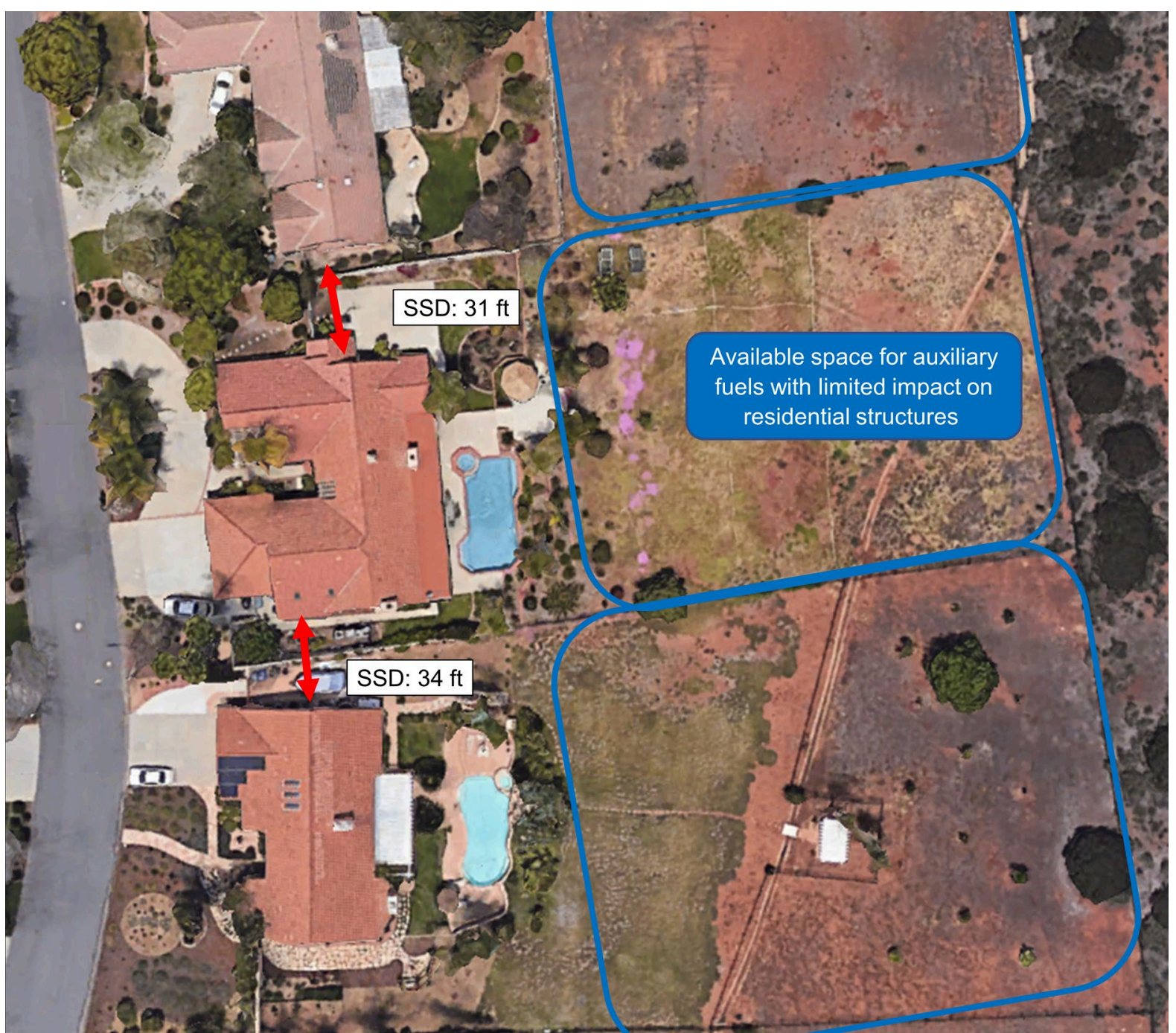

Figure 19. Scenario C, WUI Type 4 or Type 6 . While the structures are placed on large parcels with extensive backyards, the primary structures are very large with considerably smaller SSD. Selective hardening may be required in this scenario despite the large parcels. 


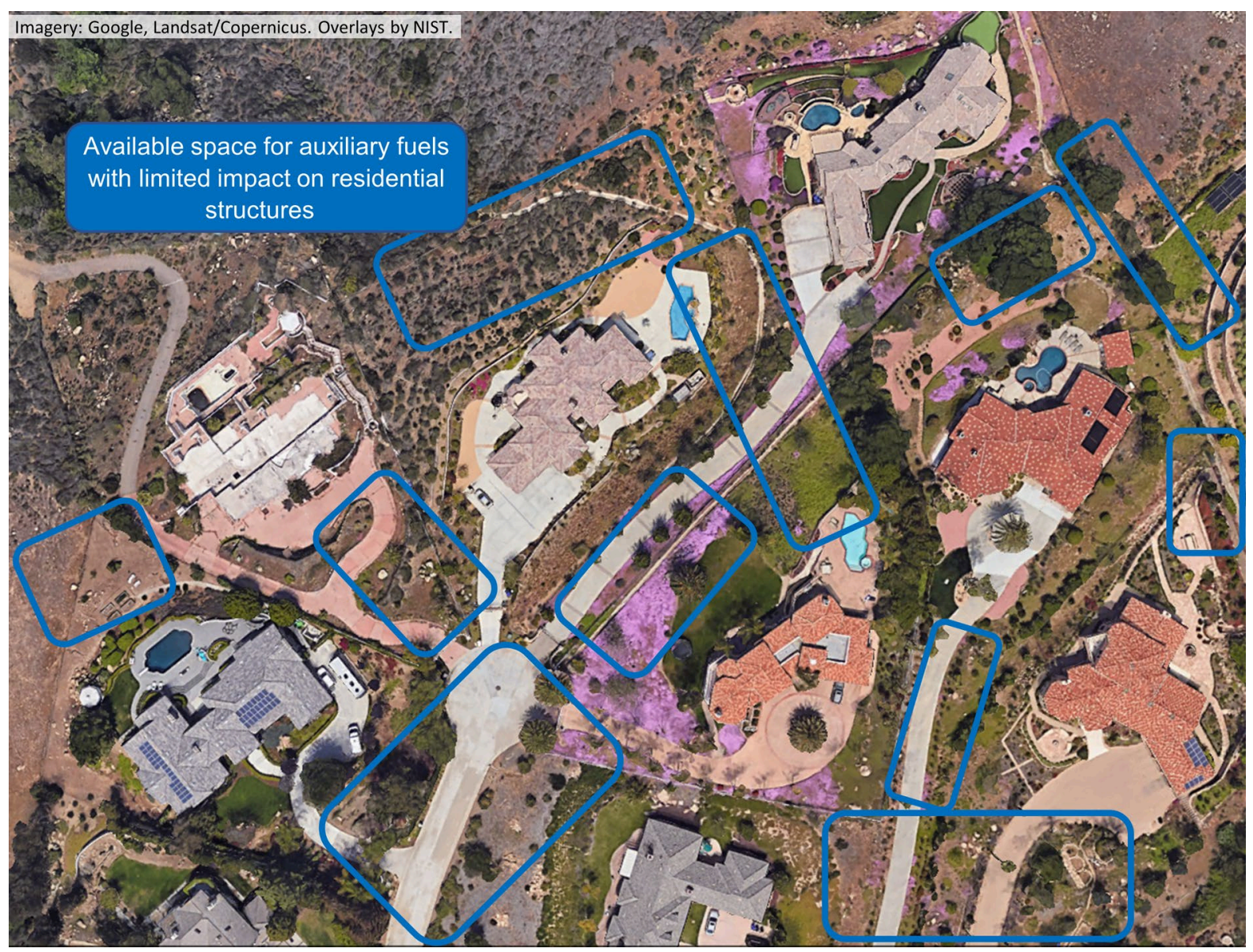

Figure 20. Scenario D, WUI Type 6. This community is characterized by large parcels with more extensive space available for auxiliary fuels. Avoidance of agglomeration of fuels within the outlined areas would influence the total number of auxiliary fuels allowed in these spaces. 


\subsection{Factors Influencing Structure Survivability}

Four primary factors influence the impact of structure hardening/mitigation on structure survivability in WUI fires:

- defensive actions,

- partial structure hardening,

- partial community hardening (i.e., fraction of structures/parcels within the community that are fully hardened), and

- housing density (i.e., SSD).

\subsubsection{Effects of Defensive Actions on Structure Survivability}

NIST post-fire WUI case studies, conducted together with state and local stakeholders, have identified that defensive actions by first responders have a significant impact on structure survivability. NIST WUI fire reconstructions have determined that most (>90\%) damaged structures were defended and saved by explicit first responder actions. Table 5 summarizes the defensive action/damaged structure relationship for the Witch/Guejito, Tanglewood Complex, and Waldo Canyon Fire case studies. Remote sensing has also identified the extensive contributions of defensive actions and their impact on fire containment $[42,43]$.

Table 5. Defensive actions identified in NIST post-fire case studies.

\begin{tabular}{|c|c|c|c|c|}
\hline Case Study & $\begin{array}{l}\text { Structures in } \\
\text { Case Study }\end{array}$ & $\begin{array}{l}\text { Damaged } \\
\text { Structures } \\
\end{array}$ & $\begin{array}{c}\text { Damaged } \\
\text { Structures } \\
\text { Identified as } \\
\text { Defended }\end{array}$ & $\begin{array}{c}\% \text { of } \\
\text { Damaged } \\
\text { Structures } \\
\text { Identified as } \\
\text { Defended } \\
\end{array}$ \\
\hline Witch/Guejito & 245 & 16 & 15 & $94 \%$ \\
\hline Tanglewood Complex & 179 & 13 & 11 & $85 \%$ \\
\hline Waldo Canyon & 1455 & 101 & 94 & $93 \%$ \\
\hline
\end{tabular}

The second important finding between defensive actions and structure survivability is that many structures are often defended that are not damaged or destroyed. This was observed during both the Witch/Guejito and the Waldo Canyon Fire case studies. During the Waldo Canyon case study 154 of the 397 undamaged structures within the fire perimeter were identified as being defended (39\%). This number does not include additional actions that were taken at the parcel level which might have indirectly saved structures by reducing exposures and stopping fire spread further from the structure.

These two findings have significant implications on assessing the WUI built environment. The percentages of identified first responders that extinguished and saved the ignited 
structures suggests that if a home in a WUI event is damaged it was more than likely defended and that an ignited structure will not survive unless actively defended. Both the Witch/Guejito and the Waldo Canyon Fire case studies confirmed that not only were a large fraction of the undamaged homes defended but also that, in many cases, these defensive actions were not always readily identifiable in the field (during or after WUI fires). The NIST WUI data collection methodology has enabled the identification of such actions through detailed technical discussions with large fractions of the first responders involved in each incident.

Exposures have been demonstrated to vary at a sub-parcel level in all NIST case studies [4-8, 32]. Additionally, information from field data collection does not indicate that the varying exposures and defensive actions "average out" throughout an incident. All these findings suggest that post-fire analysis of damage and survivability should not be conducted in the absence of defensive action data. Any assessments not accounting for defensive actions will likely be incomplete and possibly inaccurate.

The occurrence of large WUI fires, like the Tubbs and Camp Fires, together with the numerous fire storms that have occurred in California since 2000, suggest that structures must be designed to stand alone as the number of exposed structures can quickly outnumber statewide resources. Defensible space contributes to making structures defensible by first responders; however, this is not a substitute for homes standing completely alone throughout a WUI fire event.

\subsubsection{Impacts of Structure Mitigation Compliance on Structure Resilience}

The impact of partial hardening on structure survivability is not directly proportional to the fraction of hardening actions implemented. As an example, doing half of the ember hardening specified in Table A (see Appendix A) does not automatically translate to a $50 \%$ increase in ignition resistance. The relationship between effectiveness of partial hardening and local exposures can be represented by the following statement:

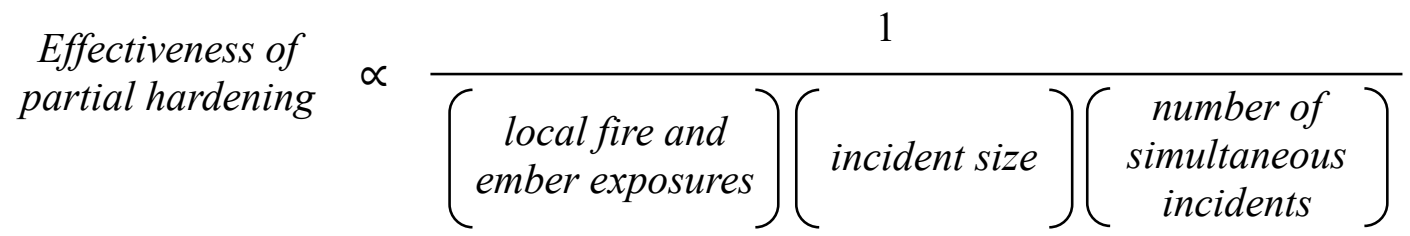

If the structure of interest receives very limited exposures, then the effectiveness of partial hardening is increased. Considering the $50 \%$ ember hardening scenario discussed previously - if a structure is in a location where only very few embers land on it, there is a better chance of survival. However, the high exposure scenario is quite different. If very high ember exposures impact the structure, it is improbable that the structure will survive unless all the ember hardening identified in Table $\mathbf{A}$ had been implemented. That is because in high ember exposures, where thousands and thousands of embers hit the structure, it is likely that 
embers will "find" one or more of these vulnerabilities and cause the structure to ignite. The same concept applies to hardening structures for fire exposures. If a structure is only partially hardened and the weak spot ignites, the otherwise hardened components will have limited to no effect on structure survivability once the structure has ignited. In this situation only timely defensive actions will result in a damaged, rather than destroyed, structure.

The increase in incident size has a negative effect on partial structure hardening. As the incident gets larger (in terms of area and number of structures ignited), the number of available first responders per residence or parcel decreases. This also holds true in the event of a fire storm where the finite number of first responders will have to respond to multiple WUI fires, further reducing the number of responders per residence or parcel.

It should be noted that among local fire and ember exposures, incident size, and number of simultaneous incidents, the only potential control that can be exercised is the reduction of fire exposures at the parcel level. Fuel reduction, displacement, and removal will all impact local exposures. However, the ember exposures will only be partially impacted as embers can travel from far beyond residential parcel boundaries; therefore, hardening is required.

The above can be summarized by saying partial ember hardening only adds some value in low exposure conditions, and almost no value in high exposure conditions. The localized variability of fire behavior results in unpredictable ember exposures. Full ember hardening is necessary to enable structures to stand alone during high ember exposures. The same holds true for fire exposures. Suppose a combustible, and readily ignitable, auxiliary structure or $\mathrm{RV}$ is located too close to a home, and there is significant fire or ember activity on the parcel. In that case, there is a likelihood that the auxiliary structure or RV will ignite and proceed to ignite the structure. Therefore, to stand alone, the structure must be evaluated and fully hardened for embers, and the structure and parcel hardened for fire where necessary.

\subsubsection{Impacts of Community Mitigation Compliance on Community Resilience}

The impact of a partially hardened structure on the community is inversely related to SSD; partially hardened structures need to be further apart.

In low density communities, a structure ignition will increase local ember exposures; observations have shown these ember exposures to be significant in the first $300 \mathrm{ft}$ downwind [4]. ${ }^{11}$ Locally there will also be increased exposures from fire (radiation and/or convection). These exposures may impact parcel-level combustible features; however, there should not be any direct fire exposures to adjacent properties due to larger SSD. The impact to the adjacent properties and community will be indirect in terms of fire, and possibly low for ember exposures (because of the large SSDs). Therefore, in low density communities with large SSDs the impact of structure ignition on the surrounding structures is low.

\footnotetext{
${ }^{11}$ Data collected from the Waldo Canyon Fire case study showed embers from burning structures resulted in structure ignitions $200 \mathrm{ft}$ to $300 \mathrm{ft}$ downwind.
} 
In moderate density communities, a structure ignition can ignite an adjacent property under a "favorable" wind direction and other local conditions. The embers generated from a burning structure will generate significantly higher exposures to the downwind structures relative to the low-density case due to separation distance. Compared to low density, the relative impact of a structure ignition to the surrounding structures can be seen as medium.

However, high density communities are in a very different exposure category. Here the ignition of a structure will almost invariably result in the ignition of one or more adjacent properties and will likely result in the loss of a significant fraction of the community, as evidenced by several large loss WUI fires in the U.S. This is not only because fire spread occurs very easily between tightly spaced structures, but also because it is very difficult to contain a fully involved structure fire, even when only moderate winds of $10 \mathrm{mi} / \mathrm{h}$ to $15 \mathrm{mi} / \mathrm{h}$ are present. Fire spread is difficult to stop as it is very challenging to remove/block the heat between residential buildings when they are constructed $6 \mathrm{ft}$ to $10 \mathrm{ft}$ apart. ${ }^{12} \mathrm{In}$ high-density construction, a single ignition can have a disproportionate impact on the overall community losses.

\subsubsection{Effects of Housing Density on Mitigation Strategies}

The fire spread information provided in this report can be used to develop an overall community WUI mitigation strategy. The community response specifically in terms of community participation is summarized in Table $\mathbf{3}$. The primary technical messages for the different structure density and WUI types are listed below.

\section{High Density Communities}

Community participation is necessary in high-density communities. This is due to the disproportionate impact of a single structure ignition on the community. There are many ways to accomplish this via voluntary or mandatory community hazard mitigation programs. Different programs can be implemented using HOA, county, or state rules and regulations. The design and implementation of such programs are beyond the scope of this report. What is important in these communities is to harden the structures and parcels for ember exposures, as these can originate from outside the community, and also ensure that there are no fire spread pathways that can generate fire exposures to residences. In certain scenarios, additional protection may be provided by structure cladding (siding and roofing) hardening requirements (such as included in CA Chapter 7A). While these requirements add significant value for protecting against low and moderate exposures, they will frequently not be able to cope with the full exposure assault of a residence burning $6 \mathrm{ft}$ to $10 \mathrm{ft}$ away because of limitations of one of the components in the wall or roof assemblies. Parcel-level hardening is a critical requirement in these high-density communities, and auxiliary fuel removal (instead of displacement) will likely be necessary on very small lots. A key issue that will need to be addressed is the presence of vehicles in the community, as they can generate locally high fire exposures resulting in structure ignitions.

\footnotetext{
${ }^{12}$ Common building setback requirements are often $3 \mathrm{ft}$ to $5 \mathrm{ft}$ from the property line.
} 
Ongoing research by NIST, CAL FIRE, and IBHS aims to provide guidance on minimum spacing between vehicles and residences in the future.

\section{Moderate Density Communities}

Moderate density communities offer more options to residents for community participation in hazard mitigation. In moderate density construction, the ignition of a single residence may directly impact one or more adjacent residences. However, direct fire (via radiation and convection) progression across the community will depend on local construction, spacing, and fuels more than in high density. Here there is an opportunity to slow down that fire spread and reduce the structure ignition pathways by selectively hardening structure sides that may see increased exposures. This selective structure hardening reduces overall community hardening program costs while increasing community resilience. Hardening of all structures for embers is still necessary in these communities. Fuel displacement, reduction, and removal may also need to be implemented to reduce fire exposures.

\section{Low Density Communities}

These community types, by the nature of their structure density, do not present a direct structure to structure fire spread pathway as can be expected in high density and certain moderate density configurations. These larger parcels also offer a significantly large number of fuel displacement options to residents, as auxiliary parcel level fuels can be placed where they will not impact other fuels, the primary residence, or neighboring structures. The notion of sacrificial auxiliary structures/features can be introduced in this setting; a resident with a large lot may be willing to accept the loss of an auxiliary structure that is located far from their residence or other features to be protected. In a low-density community this may be a readily acceptable hazard if the residence is hardened for ember exposures and all other potential fire propagation pathways near the residence have been disrupted (using the provided methodology). 


\section{Frequently Asked Questions}

A few common scenarios are presented in a question-and-answer format to provide examples of the thought process behind applying the HMM to each case. Questions are posed as if they are from homeowners with an interest in personal and community mitigation.

\section{Q: I live in a high-density community. What can I do to prevent my structure from burning during a WUI fire?}

A: There are three steps that you can take to increase the likelihood of your home surviving a WUI fire:

1. Apply the methodology in this report to your home and parcel. You will need to harden your home against embers and evaluate and address any potential fire exposures within your parcel. This may require you to reduce, relocate, replace, and possibly remove some auxiliary parcel-level fuels.

2. Work with your neighbors and get them to engage and follow the same practices.

3. In your high-density community you will want to get as many residents as possible to follow the hazard mitigation methodology. To accomplish this, you could engage your community (via a homeowner's association (HOA), if present) as well as your local and county representatives (e.g., FireSafe Councils, Firewise USA, and local town/city/county jurisdictions) about implementing community-wide tools for hazard reduction. Whether the tools are mandatory or voluntary, complete community participation is essential.

\section{Q: I have a shed on my 2-acre lot that is far from any other fuels on my property. Can I keep that shed where it is?}

A: There are two parts to this answer:

1. Consider clearing the zone within $5 \mathrm{ft}$ of your shed to minimize the chance of a surface fire or embers directly igniting the shed. You can always work on hardening the exterior building materials of the shed to make it more ignition resistant; however, these actions may not be necessary if the shed itself is an acceptable loss.

2. You should also consider how your shed may impact neighboring properties. What you want to avoid is your shed posing a significant exposure to your neighbor's residence. If your shed is close to a neighboring residence, consider moving your shed elsewhere on your property. If that is not possible, consider hardening the exterior building materials of the shed to make it more ignition resistant. You can apply the methodology to harden your shed against embers and increase the likelihood that your shed will not ignite. By preventing the ignition of your shed, you are contributing to preventing the ignition of your neighbor's residence. Fire does not care about property lines, and WUI fire mitigation is a community-level effort. You want to work with your neighbors to protect their home, as you may need their help to protect your own home. 


\section{Q: I have a half-acre lot and my neighbors are 60 feet away. My home is older and does not have a hardened wall cladding (siding). Do I need to replace my wall cladding (siding)?}

A: There are three parts to this answer:

1. First make sure that your residence is hardened for ember exposures. You should address all 40 vulnerabilities identified in this methodology.

2. Look at your parcel and make sure you do not have any parcel-level pathways that can bring fire to your residence. Address any potential fire spread pathways (e.g., fence to house, fence to vehicle to house) by reducing, relocating, replacing, and possibly removing, auxiliary parcel-level fuels.

3. The exposure from your neighboring structure is beyond the special limit outlined in the Hazard Mitigation Methodology. However, if your cladding is old and you are concerned that local conditions may cause significant fire exposures, you can consider replacing the cladding only in the direction (side) that is facing your neighbor's residence. This will reduce the overall mitigation expense. 


\section{Comparison of this Hazard Mitigation Methodology with National and International WUI Codes}

None of the current codes/best practices implement the breadth of mitigation components considered in the HMM, and none of them harden as extensively as the HMM requires.

Table A includes 40 items with a total of 57 options to specifically address structure hardening for ember exposures. The list encompasses all currently identified vulnerabilities; however, some structures may not have all of the vulnerabilities identified, and vulnerabilities to embers not currently identified in the HMM may also exist. All of the ember ignition vulnerabilities present on each individual structure need to be addressed to significantly enhance ignition resistance. An additional 10 structure ignition vulnerabilities are identified in Table D to harden for fire exposures identified in Table B and Table $\mathbf{C}$.

Table 6 below summarizes the number of options completely included in each of the selected WUI building codes for both fire and ember vulnerabilities. While a lot of ember and fire hardening information is included in the compared codes, the exact requirements outlined in HMM are only identified in the existing codes in limited numbers. Fire progression and structure hardening at the component and assembly level requires very detailed and exact guidance. The detailed information presented in this document is based on the latest science and field observation data. Appendix B contains a tabulated list of detailed comparisons of primary solutions listed in the analyzed building codes, in Table E.

The differences between the compared codes and best practices and HMM may be due to different goals and objectives. Some codes may emphasize defensible space and explicitly rely on first responders to save structures, while other best practices may focus on engaging residents, providing education, and/or starting community participation. The purpose of the HMM is to present implementable guidance to significantly increase the likelihood of structure survival without external intervention in the form of defensive actions. This was set as the structure protection criteria because the predominance of large WUI events and fire storms in the last twenty years point to that need.

Table 6. HMM items completely included in selected existing WUI building codes.

\begin{tabular}{lcccc}
\hline & $\begin{array}{c}\text { Number of } \\
\text { ember items } \\
\text { from Table } \mathbf{A} \\
\text { (out of } 57 \text { ) }\end{array}$ & $\begin{array}{c}\text { \% of ember } \\
\text { items }\end{array}$ & $\begin{array}{c}\text { Number of } \\
\text { fire items from } \\
\text { Table } \mathbf{D} \\
\text { (out of 10) }\end{array}$ & $\begin{array}{c}\text { \% of fire } \\
\text { items }\end{array}$ \\
\hline 7A/1140/IWUIC & 5 to 13 & 9 to 23 & 0 to 5 & 0 to 50 \\
All 3 codes & 3 & 5 & 0 & 0 \\
None & 42 & 74 & 5 & 50 \\
\hline
\end{tabular}




\section{Summary}

WUI fires have grown in intensity, frequency, and devastation in the past twenty years. NIST, CAL FIRE, and IBHS have developed the Hazard Mitigation Methodology detailed in this report. The goal of HMM is to reduce the vulnerability of structures and parcels in a cost-efficient and implementable way. The HMM was conceived to allow structures in the WUI to "stand alone" and survive fire and ember exposures without contributions from first responders. This was deemed necessary as field data has demonstrated that wildfire progression can quickly outpace the efforts of first responders during large and/or concurrent WUI fires. NIST WUI reconstruction data has also shown the efficient and effective structure protection actions by first responders; very little or no meaningful improvement can be achieved in this area. The emphasis must be shifted to making structures stand alone.

This HMM has outlined a detailed structure hardening strategy to resist ignitions from ember exposures. The 40 identified structure ignition vulnerabilities illustrate how detailed structure hardening must be for a structure to stand alone. Structures in the WUI need to be protected against ember exposures independent of WUI Type and housing density. This list goes significantly beyond what is outlined in many best practice documents currently available to WUI residents. The spatial analysis used in the HMM was developed specifically to address fire (radiation and convection) exposures within and across parcels. The latest science and expert knowledge combining decades of field observations were used to develop the spatial relationships outlined in the HMM. Discussions with the building industry were necessary to clarify and improve different implementation solutions.

Full community participation will be critical to hardening existing high-density communities. This document has outlined a technical path forward to accomplish this. The methodology was also developed specifically to reduce the overall financial burden of mitigation. The preferential/partial use of this methodology is undesirable and provides only very limited actual structure ignition resistance.

HMM was developed based on how fire spreads between and across parcels, as fire behavior does not respect parcel boundaries. HMM was developed utilizing the principles of fuel reduction, relocation, and removal. By implementing the HMM, residents and communities can significantly reduce structural losses from future WUI fires.

NIST and IBHS are non-regulatory entities, while CAL FIRE has regulatory authority in the state of California. This HMM was developed to provide AHJs and homeowners with the latest comprehensive understanding of fire behavior and structure response in the WUI. This report has demonstrated the benefits of using HMM as it is designed and presented here, as well as the limitations of partial implementation. Regulatory agencies and homeowners will choose where to implement any or all of the components presented in the HMM. Future hazard mitigation research (including laboratory and field observations) will be incorporated into the methodology to further enhance its effectiveness. 


\section{Summary of Key Technical Principles}

This section contains two types of technical principles. The first is a list of specific principles followed by two lists of generalized relationships between exposures, structure hardening, and community survivability.

In the WUI, structures can experience two distinct fire exposure problems/hazards-embers and fire. Following are three sets of technical principles specific to fire, embers, and parcel/community hazard mitigation implementation.

\section{Embers}

1. Ember exposures to the residence/parcel to be protected can originate from adjacent and/or far field parcels and are beyond the control of the owner of the parcel being protected.

2. Increased ignition resistance of features and specific combustion considerations can decrease ember generation.

3. Large surface area combustibles (e.g., combustible roof) contribute significantly to the ember ignition hazard.

4. Large ember exposures can be generated and observed in WUI fire incidents. Ember exposures can vary significantly in space and time.

5. The potential for high ember exposures drives the need to harden structures against ember exposures completely.

6. Partial structure hardening for embers does not relate linearly to hazard reduction. $90 \%$ ember hardening does not translate to $90 \%$ risk reduction.

7. In high ember exposures, complete ember hardening ( $100 \%$ compliance) is necessary to significantly reduce the structure ignition potential from embers.

Fire

8. Fire represents a direct and indirect exposure hazard to residences, commercial structures, and infrastructure in the WUI. Direct exposures occur when a source (item burning) directly impacts a target, in this case a residence or commercial structure. Indirect exposures occur when a source ignites a secondary fuel, impacting the target.

9. Fire exposure increases via fuels agglomeration. Increased fire exposures can then potentially impact the residence/commercial structure. Increased exposure also negatively impacts defensible space, making it more hazardous for first responders to conduct firefighting and rescue operations.

10. A property owner can control and reduce fire exposures to their residence/commercial structure by managing their parcel-level combustibles.

11. A property owner may not be able to control fire exposures from adjacent parcels. 


\section{Parcel/Community}

12. The parcel size and placement of structure(s) will determine structure-to-structure exposures within the parcel and to adjacent parcels.

13. Structure separation distances have significant impact on fire propagation in the WUI.

14. Fuel relocation, reduction, and/or removal should be considered when addressing parcel hardening independent of WUI housing density.

15. Even if certain parcel-level combustible features are seen as expendable/disposable in the context of parcel hardening, the impact of these features must be considered in the context of fuels agglomeration and exposures to structures and other nearby combustibles.

16. In high-density WUI communities, fuel removal may be necessary to comply with the HMM and reduce structural losses.

The following lists contain information intended to capture the relationships between exposures, parcel and structure hardening, and community structural losses. The relationships illustrated here are intended to provide relative performances and highlight trends and critical thresholds. Actual conditions, including construction, parcel sizes and fuel loading, structure separation distances, parcel and structure hardening, local weather, ignition sequencing, and defensive actions, will impact actual fire spread and community resilience.

\section{General Relationships between Exposure and Hardening}

1. Low fire exposures are relatively easy to address by hardening the structure.

2. High fire exposures (direct flame impingement from large sources such as a burning residence) are very difficult to address by hardening the structure. This is because both the cladding (siding and roofing) material and the assembly need to be hardened not only to withstand the exposure but also to withstand it for the entire exposure duration, therefore potentially propagating energy into the assembly past the external cladding component.

3. Fire exposures from a fully involved single family residence will result in fire propagation that will be very difficult to stop in the presence of wind in high density communities.

4. High fire exposures can readily cause direct ignition of exposed combustibles.

5. The ember hardening and structure survivability relationship is not linear. Hardening $80 \%$ of the vulnerabilities will not necessarily result in $80 \%$ decrease in structure ignition potential. While the actual values will vary based on local conditions and specifics of hardening, the relationship will apply to almost all scenarios.

6. In situations where a potential fuel source is located near a residential/commercial structure and when fuel reduction, relocation, or removal cannot alleviate severe fire exposures to that structure, hardening the structure for fire may frequently add limited value. In these situations, ignition prevention of the fuel source will be the critical path to reducing the ignition of the residential/commercial structure. 
General Relationships between Structure/Parcel Hardening Compliance and Community Survivability

1. Partial community compliance, in the form of incomplete structure and parcel hardening, has limited impact beyond the partially hardened properties in a lowdensity community.

2. Partial community compliance, in the form of incomplete structure and parcel hardening, has moderate impacts beyond the partially hardened properties in a moderate-density community.

3. Partial community compliance, in the form of incomplete structure and parcel hardening, has very significant impacts across the entire community in high- density communities. Just a few partially hardened properties can jeopardize an entire highdensity community. 


\section{Acknowledgments}

The authors would like to acknowledge the productive collaboration among CAL FIRE, IBHS, and NIST. Additionally, the authors would like to thank the following individuals for providing input to the report and participating in the review process; Derek McNamara (Geospatial Measurement Solutions, LLC), Kuma Sumathipala (American Wood Council), Karl Fippinger (International Code Council), Karen Jackson (Texas Forest Service, Retired), Jonathan Griffin (NIST Public Affairs Office), Glenn Forney (NIST Fire Research Division), Tom Cleary (NIST Fire Research Division), Jiann Yang (NIST Fire Research Division), and the NIST Editorial Review Board. 


\section{References}

[1] Weber K.T. , Yadav R. (2020) Spatiotemporal Trends in Wildfires across the Western United States (1950-2019). Remote Sensing 12:2959.

https://doi.org/10.3390/rs12182959

[2] Buechi H., et al. (2020) Long-term trends in wildfire damages in California. emLab at UC Santa Barbara. https://emlab.ucsb.edu/sites/default/files/documents/wildfirebrief.pdf. Accessed: January 2022.

[3] CAL FIRE (2021) Top 20 Most Destructive California Wildfires. (Updated October 25, 2021) Available at https://www.fire.ca.gov/media/t1rdhizr/top20_destruction.pdf. Accessed: January 2022.

[4] Maranghides A., et al. (2015) A Case Study of a Community Affected by the Waldo Fire - Event Timeline and Defensive Actions. NIST Technical Note 1910. National Institute of Standards and Technology, Gaithersburg, MD. https://doi.org/10.6028/NIST.TN.1910

[5] Maranghides A. , McNamara D. (2016) 2011 Wildland Urban Interface Amarillo Fires Report \#2 - Assessment of Fire Behavior and WUI Measurement Science. NIST Technical Note 1909. National Institute of Standards and Technology, Gaithersburg, MD. https://doi.org/10.6028/NIST.TN.1909

[6] Maranghides A., et al. (2011) Initial Reconnaissance of the 2011 Wildland-Urban Interface Fires in Amarillo, Texas. NIST Technical Note 1708. National Institute of Standards and Technology, Gaithersburg, MD. https://doi.org/10.6028/NIST.TN.1708

[7] Maranghides A., et al. (2021) A Case Study of the Camp Fire - Fire Progression Timeline. NIST Technical Note 2135. National Institute of Standards and Technology, Gaithersburg, MD. https://doi.org/10.6028/NIST.TN.2135

[8] Maranghides A., Mell W. (2009) A Case Study of a Community Affected by the Witch and Guejito Fires. NIST Technical Note 1635. National Institute of Standards and Technology, Gaithersburg, MD. https://doi.org/10.6028/NIST.TN.1635

[9] Maranghides A., Mell W. (2013) Framework for Addressing the National Wildland Urban Interface Fire Problem - Determining Fire and Ember Exposure Zones using a WUI Hazard Scale. NIST Technical Note 1748. National Institute of Standards and Technology, Gaithersburg, MD. https://doi.org/10.6028/NIST.TN.1748

[10] Johnston L., Blanchi R., Jappiot M. (2019) Wildland-Urban Interface. In: Manzello S.L. (ed) Encyclopedia of Wildland-Urban Interface (WUI) Fires. Springer, Cham. https://doi.org/10.1007/978-3-319-51727-8_130-1

[11] US Department of Agriculture, US Department of Interior (2001) Urban Wildland Interface Communities Within the Vicinity of Federal Lands That Are at High Risk From Wildfire. Federal Register 66(3):751-777.

https://www.federalregister.gov/d/01-52 
[12] Davis J.B. (1989) Demography: A Tool for Understanding the Wildland-Urban Interface Fire Problems. Proceedings of the Symposium on Fire and Watershed Management (Oct. 26-28, 1988, Sacramento, CA), General Technical Report PSW109, ed Berg N.H. (USDA Forest Service, Pacific Southwest Forest and Range Experiment Station, Berkeley, CA), pp 38-42.

[13] GAO (2003) Wildland Fire Management: Additional Actions Required to Better Identify and Prioritize Lands Needing Fuels Reduction. GAO-03-805. U.S. General Accounting Office, Washington, D.C. https://www.gao.gov/assets/gao-03-805.pdf. Accessed: December 2021.

[14] Stewart S.I., et al. (2007) Defining the Wildland-Urban Interface. Journal of Forestry 105(4):201-207.

[15] Mell W.E., et al. (2010) The wildland-urban interface fire problem-current approaches and research needs. International Journal of Wildland Fire 19:238-251. https://doi.org/10.1071/WF07131

[16] Healthy Forests Restoration Act of 2003, 16 U.S.C. § 6511, (2003) (https://www.govinfo.gov/content/pkg/USCODE-2003-title16/pdf/USCODE-2003title16.pdf)

[17] Radeloff V.C., et al. (2005) The Wildland-Urban Interface in the United States. Ecological Applications 15(3):799-805.

[18] Martinuzzi S., et al. (2015) The 2010 wildland-urban interface of the conterminous United States (NRS-RMAP-8). U.S. Department of Agriculture, Forest Service, Newtown Square, PA. https://doi.org/10.2737/NRS-RMAP-8

[19] Wilmer B.G. , Aplet G. (2005) Targeting the Community Fire Planning Zone: Mapping Matters. The Wilderness Society, Washington, D.C.

[20] Theobald D.M. , Romme W.H. (2007) Expansion of the US wildlan-urban interface. Landscape and Urban Planning 83:340-354. https://doi.org/10.1016/j.landurbplan.2007.06.002

[21] Platt R.V. (2010) The Wildland-Urban Interface: Evaluating the Definition Effect. Journal of Forestry 108(1):9-15.

[22] Stewart S.I., et al. (2009) Wildland-Urban Interface Maps Vary with Purpose and Context. Journal of Forestry 107(2):78-83. https://www.fs.fed.us/rm/pubs other/rmrs_2009 stewart_s001.pdf

[23] Greetan J.D. (2016) The Wildland-Urban Interface in Lassen County, California: A Change Analysis 2000-2015 [Masters Thesis]. (University of Southern California, Los Angeles, CA). Retrieved from https://spatial.usc.edu/wpcontent/uploads/formidable/12/Josh-Greetan.pdf. Accessed: December 2021.

[24] Kramer H.A., et al. (2019) High wildfire damage in interface communities in California. International Journal of Wildland Fire 28(9). https://doi.org/10.1071/wf18108

[25] Cal. Pub. Res. Code $\S 4201-4204$, (Fire Hazard Severity Zones) 
[26] CAL FIRE (n.d.) Fire Hazard Severity Zones. Available at https://osfm.fire.ca.gov/divisions/wildfire-planning-engineering/wildfire-preventionengineering/fire-hazard-severity-zones/. Accessed: December 2021.

[27] California Building Standards Commission (2019) Chapter 7A: Materials and Construction Methods for Exterior Wildfire Exposure. 2019 California Building Code (Cal. Code Regs., Title 24, Part 2), (International Code Council, Inc.).

[28] California Building Standards Commission (2019) Chapter 49: Requirements for Wildland-Urban Interface Fire Areas. 2019 California Fire Code (Cal. Code Regs., Title 24, Part 9), (International Code Council, Inc.).

[29] Cal. Gov. Code $\S 51175-51189$, (2020) (Very High Fire Hazard Severity Zones)

[30] LANDFIRE (n.d.) Available at https://www.landfire.gov/. Accessed: January 2022.

[31] Maranghides A., Johnsson E.L. (2008) Residential Structure Separation Fire Experiments. NIST Technical Note 1600. National Institute of Standards and Technology, Gaithersburg, MD. https://doi.org/10.6028/NIST.TN.1600

[32] Maranghides A., et al. (2013) A Case Study of a Community Affected by the Witch and Guejito Fires Report: \#2 - Evaluating the Effects of Hazard Mitigation Actions on Structure Ignitions. NIST Technical Note 1796. National Institute of Standards and Technology, Gaithersburg, MD. https://doi.org/10.6028/NIST.TN.1796

[33] CAL FIRE (n.d.) Defensible Space. Available at https://www.readyforwildfire.org/prepare-for-wildfire/get-ready/defensible-space/. Accessed: January 2022.

[34] Caton S.E., et al. (2016) Review of Pathways for Building Fire Spread in the Wildland Urban Interface Part I: Exposure Conditions. Fire Technology 53(2):429473. https://doi.org/10.1007/s10694-016-0589-z

[35] El Houssami M., et al. (2016) Experimental Procedures Characterising Firebrand Generation in Wildland Fires. Fire Technology 52(3):731-751. https://doi.org/10.1007/s10694-015-0492-z

[36] Suzuki S. , Manzello S.L. (2018) Characteristics of Firebrands Collected from Actual Urban Fires. Fire Technology. https://doi.org/10.1007/s10694-018-0751-x

[37] Thomas J.C., et al. (2017) Investigation of firebrand generation from an experimental fire: Development of a reliable data collection methodology. Fire Saf J 91:864-871. https://doi.org/10.1016/j.firesaf.2017.04.002

[38] Bouvet N., Link E.D., Fink S.A. (2020) Development of a New Approach to Characterize Firebrand Showers During Wildland-Urban Interface (WUI) Fires: a Step Towards High-Fidelity Measurements in Three Dimensions. NIST Technical Note 2093. National Institute of Standards and Technology, Gaithersburg, MD. https://doi.org/10.6028/NIST.TN.2093

[39] Bouvet N., Link E.D., Fink S.A. (2021) A new approach to characterize firebrand showers using advanced 3D imaging techniques. Experiments in Fluids 62:181. https://doi.org/10.1007/s00348-021-03277-6 
[40] Hakes R.S.P., et al. (2016) A Review of Pathways for Building Fire Spread in the Wildland Urban Interface Part II: Response of Components and Systems and Mitigation Strategies in the United States. Fire Technology 53(2):475-515. https://doi.org/10.1007/s10694-016-0601-7

[41] Butler K. , et al. (2022) Wind-driven Fire Spread to a Structure from Fences and Mulch. NIST Technical Note (in progress). National Institute of Standards and Technology, Gaithersburg, MD.

[42] McNamara D., Mell W., Maranghides A. (2020) Object-based post-fire aerial image classification for building damage, destruction and defensive actions at the 2012 Colorado Waldo Canyon Fire. International Journal of Wildland Fire 29:174-189. https://doi.org/10.1071/WF19041

[43] McNamara D. , Mell W. (2022) Towards the use of Remote Sensing for Identification of Building Damage, Destruction, and Defensive Actions at Wildland-Urban Interface Fires. Fire Technology 58:641-672. https://doi.org/10.1007/s10694-021$\underline{01170-6}$ 


\section{Appendix A. Home Hardening Requirements}

The following tables identify the various potential structure and parcel ignition vulnerabilities and their associated mitigation options.

Table A specifically addresses hardening against ember exposures. Table $\mathbf{B}$ and Table $\mathbf{C}$ list hazards from adjacent parcels and hazards from within the parcel containing the residence being protected. These tables are linked spatially to Table $\mathbf{D}$, which contains structure hardening requirements for exposures from fire (flames and radiation).

Table $\mathbf{A}$ is divided into 8 major categories (e.g., roof, walls, vents, etc.) listing specific structural components or assemblies. The table contains columns listing the hardening action, the performance goal of the action, and the applicable conditions associated with each component. Also included are any brief notes, and a column estimating relative cost of each action. The final column indicates which of the selected existing WUI building codes (CA Building Code Chapter 7A, NFPA 1140, and ICC IWUIC) address the specific hazard to the necessary detail.

Table B addresses parcel fire exposures to the primary residence from far-field fuels included in adjacent parcels. For each fire-emanating source (e.g., neighboring structure, wildland fuels) a minimum required fuel separation distance (MFSD) or fuel separation range (FSR) is provided. If the hazard is located closer than the listed MFSD, or within the listed FSR, structure hardening must be addressed via Table D. If the fuel is further than the listed distances, no hardening action is required for fire exposures. If the fuel is closer to the structure being protected than the listed FSR, hardening for fire will have limited impact due to the expected severity of the exposure, and is therefore not required in the HMM for cost savings. AHJs or homeowners may choose to add an additional level of protection by hardening in these situations.

Table $\mathbf{C}$ addresses parcel hazard mitigation and lists 9 separate types of vulnerabilities. The table contains columns on hardening actions, goals, and the applicable conditions. Similar to Table A, notes and expected relative cost are included. As in Table B, MFSDs are provided, and links to Table $\mathbf{D}$ when spatial conditions require mitigating action.

Table D lists 10 separate structure components requiring hardening for fire exposures. The use of Table $\mathbf{D}$ is driven by the spatial requirements identified in Table $\mathbf{B}$ and Table $\mathbf{C}$. Similar to the other tables, columns are included for hardening action, the performance goal, and the applicable conditions of the component/assembly. Columns for notes and expected relative cost are also provided. As in Table A, comparison to selected existing codes is also included. 
Table A. Structure and attached combustible hardening against ignition from embers.

\begin{tabular}{|c|c|c|c|c|c|c|c|}
\hline $\begin{array}{c}\text { Item } \\
\#\end{array}$ & $\begin{array}{l}\text { Structure Component, Assembly, or } \\
\text { Attached Combustible }\end{array}$ & Hardening Action & Performance Goal & Applicable Condition(s) & Notes & $\begin{array}{c}\text { Expected } \\
\text { Cost Range } \\
(\$, \$ \$, \$ \$ \$)\end{array}$ & $\begin{array}{l}\text { Matched in } \\
\text { Existing } \\
\text { Code }\end{array}$ \\
\hline \multicolumn{8}{|l|}{ Roof } \\
\hline 1 & Skylights & $\begin{array}{l}\text { Replace plastic skylight with } \\
\text { multipaned glass with tempered glass } \\
\text { outer pane. If skylight opens, install } \\
\text { metal screen on the inside. If screen is } \\
\text { non-metal replace with metal. }\end{array}$ & $\begin{array}{l}\text { Minimize embers with enough energy to } \\
\text { cause ignitions }\end{array}$ & $\begin{array}{l}\text { Plastic skylight pane, nonmetal screen, } \\
\text { no screen }\end{array}$ & $\begin{array}{l}\text { Screen is needed only on openable } \\
\text { skylights }\end{array}$ & $\$$ & $\begin{array}{l}\text { Chapter 7A } \\
\text { NFPA 1140 } \\
\text { ICC IWUIC }\end{array}$ \\
\hline 2 & Roof to skylight flashing & $\begin{array}{l}\text { Check for standard metal flashing and } \\
\text { that no exposed wood is present, repair } \\
\text { as necessary. }\end{array}$ & $\begin{array}{l}\text { Prevent ignition of combustible skylight } \\
\text { framing }\end{array}$ & Lack of metal flashing around skylight & $\mathrm{n} / \mathrm{a}$ & $\$$ & None \\
\hline \multirow{2}{*}{3} & \multirow{2}{*}{$\begin{array}{l}\text { Roof assembly details (i.e., dormer } \\
\text { and other roof-to-wall intersections) }\end{array}$} & Metal flashing at roof-to-wall & \multirow{2}{*}{$\begin{array}{l}\text { Prevent ignition of roof from burning } \\
\text { debris accumulation }\end{array}$} & \multirow{2}{*}{$\begin{array}{l}\text { Combustible siding at roof-to-wall } \\
\text { intersection }\end{array}$} & $\begin{array}{l}\text { Alternative option: Add the } 6 \text { inch "tall" } \\
\text { flashing over the existing siding or } \\
\text { remove the siding and put flashing on. }\end{array}$ & $\$$ & None \\
\hline & & $\begin{array}{l}\text { Replace with noncombustible siding in } \\
\text { that area only (e.g., dormer or split- } \\
\text { level residence) }\end{array}$ & & & $\begin{array}{l}\text { Preferred option: remove combustible } \\
\text { siding and replace with noncombustible } \\
\text { siding. }\end{array}$ & $\$ \$$ & None \\
\hline 4 & Solar panels & $\begin{array}{l}\text { Minimize debris accumulation under } \\
\text { and next to solar panels }\end{array}$ & $\begin{array}{l}\text { Prevent ignition of debris, solar panels, and } \\
\text { roof }\end{array}$ & Solar panels on roof & $\begin{array}{l}\text { No additional baffles or screening should } \\
\text { be installed as they may impact PV } \\
\text { cooling }\end{array}$ & $\$$ & None \\
\hline 5 & Roof covering - old wood shake & $\begin{array}{l}\text { Replace with Class A (with } \\
\text { noncombustible birdstopping, if } \\
\text { needed) }\end{array}$ & Prevent ignition of roof material & $\begin{array}{l}\text { Non-fire retardant treated wood shake } \\
\text { roof }\end{array}$ & $\mathrm{n} / \mathrm{a}$ & $\$ \$ \$$ & $\begin{array}{l}\text { Chapter 7A } \\
\text { NFPA 1140 } \\
\text { ICC IWUIC }\end{array}$ \\
\hline \multirow{2}{*}{6} & Roof covering - Class B & \multirow{2}{*}{ Replace with Class A when needed } & \multirow{2}{*}{ Prevent ignition of roof material } & $\begin{array}{l}\text { Degraded or end of life Class B roof } \\
\text { and needs replacement }\end{array}$ & \multirow{2}{*}{$\mathrm{n} / \mathrm{a}$} & \multirow{2}{*}{$\$ \$ \$$} & \multirow{2}{*}{ Chapter 7A } \\
\hline & Roof covering - Class $\mathrm{C}$ & & & $\begin{array}{l}\text { Degraded or end of life Class C roof } \\
\text { and needs replacement }\end{array}$ & & & \\
\hline 7 & $\begin{array}{l}\text { Roof covering with openings between } \\
\text { roof covering and edge or ridge }\end{array}$ & $\begin{array}{l}\text { Close/plug with noncombustible } \\
\text { material }\end{array}$ & $\begin{array}{l}\text { Prevent accumulation of debris between } \\
\text { roof covering and roof deck }\end{array}$ & $\begin{array}{l}\text { Style of roof (tile or metal) that } \\
\text { creates openings }\end{array}$ & $\mathrm{n} / \mathrm{a}$ & $\$-\$ \$$ & $\begin{array}{l}\text { Chapter 7A } \\
\text { NFPA 1140 } \\
\text { ICC IWUIC }\end{array}$ \\
\hline \multirow{3}{*}{8} & \multirow{3}{*}{ Gutters } & Noncombustible gutter cover ${ }^{\mathrm{a}}$ & $\begin{array}{l}\text { Limit accumulation of ignitable debris in } \\
\text { gutters }\end{array}$ & \multirow{3}{*}{$\begin{array}{l}\text { Combustible gutter cover or no gutter } \\
\text { cover }\end{array}$} & $\begin{array}{l}\text { If metal cover cannot be installed on } \\
\text { plastic gutter, then replace gutter with } \\
\text { metal gutter and noncombustible cover }\end{array}$ & $\$-\$ \$$ & $\begin{array}{l}\text { ICC IWUIC } \\
\text { NFPA } 1140\end{array}$ \\
\hline & & Metal drip edge & $\begin{array}{l}\text { Prevent ignition from embers, protect facia } \\
\text { and sheathing from flames }\end{array}$ & & $\begin{array}{l}\text { Certain gutters already have drip edge as } \\
\text { part of the gutter }\end{array}$ & $\$$ & None \\
\hline & & No-gutter & Prevent ignition from embers & & $\begin{array}{l}\text { Very expensive solution, less expensive } \\
\text { options are available }\end{array}$ & $\$ \$ \$$ & None \\
\hline 9 & No gutter & $\begin{array}{l}\text { Add metal flashing if fascia does not } \\
\text { cover roof sheathing }\end{array}$ & $\begin{array}{l}\text { Prevent accumulation of embers at fascia- } \\
\text { sheathing intersection }\end{array}$ & $\begin{array}{l}\text { Exposed sheathing (i.e., not covered } \\
\text { by fascia) }\end{array}$ & $\begin{array}{l}\text { May require subsurface-surface drainage } \\
\text { such as ICC } 11.01 .6\end{array}$ & $\$$ & None \\
\hline \multicolumn{8}{|c|}{ Cladding (Siding) } \\
\hline 10 & $\begin{array}{l}\text { Height of wall assembly from the } \\
\text { ground }\end{array}$ & $\begin{array}{l}\text { Replace exterior wall covering with } \\
\text { noncombustible material for the bottom } \\
2 \mathrm{ft} \text { (from ground); add metal flashing } \\
\text { to protect bottom edge of sheathing }\end{array}$ & $\begin{array}{l}\text { Prevent windblown debris and local fuels } \\
\text { from igniting the wall }\end{array}$ & All siding within $2 \mathrm{ft}$ of ground & $\begin{array}{l}\text { Metal flashing is required for all } \\
\text { claddings, including noncombustible }\end{array}$ & $\$ \$$ & None \\
\hline \multicolumn{8}{|c|}{ 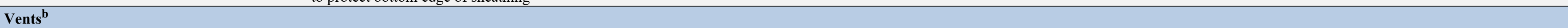 } \\
\hline \multirow{2}{*}{11} & \multirow{2}{*}{ Ridge vent } & Add metal baffle & \multirow{2}{*}{$\begin{array}{l}\text { Minimize embers with enough energy to } \\
\text { cause ignitions }\end{array}$} & $\begin{array}{l}\text { Plastic ridge vent AND installable } \\
\text { metal baffle }\end{array}$ & Metal flashing & $\$$ & None \\
\hline & & Replace ridge vent $\mathrm{w} /$ metal ridge vent & & $\begin{array}{l}\text { Plastic ridge vent AND non-installable } \\
\text { metal baffle }\end{array}$ & $\mathrm{n} / \mathrm{a}$ & $\$ \$$ & None \\
\hline
\end{tabular}




\begin{tabular}{|c|c|c|c|c|c|c|c|}
\hline $\begin{array}{c}\text { Item } \\
\#\end{array}$ & $\begin{array}{l}\text { Structure Component, Assembly, or } \\
\text { Attached Combustible }\end{array}$ & Hardening Action & Performance Goal & Applicable Condition(s) & Notes & $\begin{array}{c}\text { Expected } \\
\text { Cost Range } \\
(\$, \$ \$, \$ \$)\end{array}$ & $\begin{array}{l}\text { Matched in } \\
\text { Existing } \\
\text { Code }\end{array}$ \\
\hline 12 & Off -ridge vent & $\begin{array}{l}\text { Replace with ember and flame-resistant } \\
\text { vent }\end{array}$ & $\begin{array}{l}\text { Minimize embers with enough energy to } \\
\text { cause ignitions }\end{array}$ & Non-ember/flame resistant vent & $\mathrm{n} / \mathrm{a}$ & $\$ \$$ & Chapter 7A \\
\hline \multirow[b]{2}{*}{13} & \multirow[b]{2}{*}{ Gable vent } & Remove gable vent & \multirow{2}{*}{$\begin{array}{l}\text { Minimize embers with enough energy to } \\
\text { cause ignitions }\end{array}$} & \multirow{2}{*}{$\begin{array}{l}\text { Combustible screen and/or mesh } \\
\text { greater than } 1 / 8 \text { inch }\end{array}$} & \multirow[b]{2}{*}{$\mathrm{n} / \mathrm{a}$} & $\$ \$$ & None \\
\hline & & $\begin{array}{l}\text { Replace with ember and flame-resistant } \\
\text { vent }\end{array}$ & & & & $\$$ & Chapter 7A \\
\hline \multirow{2}{*}{14} & \multirow{2}{*}{$\begin{array}{l}\text { Under eave and any vents in the } \\
\text { under-eave area on the rake (gable) } \\
\text { end of the building }\end{array}$} & $\begin{array}{l}\text { Replace with ember and flame-resistant } \\
\text { vent, add fire caulking around all } \\
\text { blocking }\end{array}$ & \multirow{2}{*}{$\begin{array}{l}\text { Minimize embers with enough energy to } \\
\text { cause ignitions }\end{array}$} & $\begin{array}{l}\text { Non-ember/flame resistant vent and/or } \\
\text { uncaulked eaves blocking }\end{array}$ & $\mathrm{n} / \mathrm{a}$ & $\$-\$ \$$ & Chapter 7A \\
\hline & & $\begin{array}{l}\text { Create a soffited eave (horizontal) or } \\
\text { enclose eave (angled) using } \\
\text { noncombustible material }\end{array}$ & & $\begin{array}{l}\text { Non-ember/flame resistant vent and/or } \\
\text { open eave }\end{array}$ & $\begin{array}{l}\text { 1. All sides of the residence } \\
\text { 2. Angled implies following the roof line }\end{array}$ & $\$-\$ \$$ & None \\
\hline \multirow{3}{*}{15} & \multirow{3}{*}{ Crawl space vents } & $\begin{array}{l}\text { Replace with ember and flame-resistant } \\
\text { vent }\end{array}$ & \multirow{3}{*}{$\begin{array}{l}\text { Minimize embers with enough energy to } \\
\text { cause ignitions }\end{array}$} & \multirow{3}{*}{ Non-ember/flame resistant vent } & $\mathrm{n} / \mathrm{a}$ & $\$-\$ \$$ & Chapter 7A \\
\hline & & $\begin{array}{l}\text { Replace with ember and flame-resistant } \\
\text { vent and add moisture barrier }\end{array}$ & & & $\begin{array}{l}\text { Can use plastic ground cover to reduce } \\
\text { venting requirement; addition of moisture } \\
\text { barrier reduces required vent area by } 10 x\end{array}$ & $\$-\$ \$$ & $\begin{array}{l}\text { CA } \\
\text { Building } \\
\text { Code }\end{array}$ \\
\hline & & Convert to unvented crawl space & & & $\begin{array}{l}\text { Energy benefit, very expensive solution, } \\
\text { less expensive options are available }\end{array}$ & $\$ \$$ & None \\
\hline 16 & Dryer vents & Metal flapper (closed unless in use) & Limit ignition of lint and ducting & No metal flapper in place & $\mathrm{n} / \mathrm{a}$ & $\$$ & None \\
\hline 17 & Makeup air intake & $\begin{array}{l}\text { Replace with ember and flame-resistant } \\
\text { vent }\end{array}$ & $\begin{array}{l}\text { Minimize embers with enough energy to } \\
\text { cause ignitions }\end{array}$ & $\begin{array}{l}\text { Combustible screen and/or mesh } \\
\text { greater than } 1 / 8 \text { inch }\end{array}$ & $\begin{array}{l}\text { Needed in rooms within occupied portion } \\
\text { of residence where gas appliances are } \\
\text { located }\end{array}$ & $\$$ & None \\
\hline \multirow{2}{*}{18} & $\begin{array}{l}\text { Other penetrations (electrical, water) } \\
\text { to roof and walls }\end{array}$ & $\begin{array}{l}\text { Close with fire caulking and inspect } \\
\text { during routine maintenance and close } \\
\text { gaps as needed }\end{array}$ & $\begin{array}{l}\text { Minimize embers with enough energy to } \\
\text { cause ignitions }\end{array}$ & $\begin{array}{l}\text { Gaps around siding penetrations } \\
\text { greater than } 1 / 8 \text { inch }\end{array}$ & $\mathrm{n} / \mathrm{a}$ & $\$$ & None \\
\hline & Close up open space under residence & $\begin{array}{l}\text { Install noncombustible skirting on all } \\
\text { sides. Add vents as required. Vents } \\
\text { must be ember and flame resistant. }\end{array}$ & Limit ignitions under structure & $\begin{array}{l}\text { Open space under residence (e.g., pier } \\
\text { and post foundation) }\end{array}$ & $\mathrm{n} / \mathrm{a}$ & $\$ \$$ & None \\
\hline 19 & $\begin{array}{l}\text { Other attachments to mobile homes } \\
\text { (portico/car port) }\end{array}$ & $\begin{array}{l}6 \text { inches of metal flashing at the wall } \\
\text { intersection }\end{array}$ & Limit mobile home ignition & Mobile home with attachment(s) & $\mathrm{n} / \mathrm{a}$ & $\$ \$$ & $\begin{array}{l}\text { Chapter 7A } \\
\text { NFPA } 1140\end{array}$ \\
\hline 20 & Other penetrations & $\begin{array}{l}\text { Seal around penetrations with fire } \\
\text { caulking }\end{array}$ & Limit ember intrusion and accumulation & Penetrations & $\mathrm{n} / \mathrm{a}$ & $\$$ & None \\
\hline \multicolumn{8}{|c|}{ Windows } \\
\hline 21 & Window screens & Add metal screen & $\begin{array}{l}\text { Minimize embers with enough energy to } \\
\text { cause ignitions }\end{array}$ & Opening window & $\mathrm{n} / \mathrm{a}$ & $\$$ & None \\
\hline 22 & Exposed wooden frame single pane & $\begin{array}{l}\text { Replace with noncombustible frame } \\
\text { and double pane tempered glass } \\
\text { window }\end{array}$ & Prevent ignition of combustible frame & Exposed wooden frame single pane & $\begin{array}{l}\text { Moisture removal benefits, energy benefit } \\
\text { - seek cost sharing }\end{array}$ & $\$ \$$ & None \\
\hline 23 & Exposed wooden frame double pane & $\begin{array}{l}\text { Replace with noncombustible frame } \\
\text { and double pane tempered glass } \\
\text { window }\end{array}$ & Prevent ignition of combustible frame & Exposed wooden frame double pane & $\mathrm{n} / \mathrm{a}$ & $\$ \$$ & None \\
\hline \multicolumn{8}{|l|}{ Doors } \\
\hline \multirow[t]{2}{*}{24} & \multirow[t]{2}{*}{ Exterior door (non-sliding) } & $\begin{array}{l}\text { Install metal door jamb kit and metal } \\
\text { threshold; add metal kick plate, and } \\
\text { metal door bottom }\end{array}$ & \multirow[t]{2}{*}{ Limit ember ignition of door and frame } & \multirow{2}{*}{$\begin{array}{l}\text { Wood door frame and/or wooden door } \\
\text { and/or wooden threshold }\end{array}$} & \multirow[t]{2}{*}{$\mathrm{n} / \mathrm{a}$} & $\$-\$ \$$ & None \\
\hline & & $\begin{array}{l}\text { Replace with metal door with metal } \\
\text { frame and threshold }\end{array}$ & & & & $\$ \$$ & None \\
\hline
\end{tabular}




\begin{tabular}{|c|c|c|c|c|c|c|c|}
\hline $\begin{array}{c}\text { Item } \\
\#\end{array}$ & $\begin{array}{l}\text { Structure Component, Assembly, or } \\
\text { Attached Combustible }\end{array}$ & Hardening Action & Performance Goal & Applicable Condition(s) & Notes & $\begin{array}{l}\text { Expected } \\
\text { Cost Range } \\
(\$, \$ \$, \$ \$ \$)\end{array}$ & $\begin{array}{l}\text { Matched in } \\
\text { Existing } \\
\text { Code }\end{array}$ \\
\hline & Exterior Door (sliding) & $\begin{array}{l}\text { Replace with non-wood containing } \\
\text { slider with dual pane tempered glass } \\
\text { and with a metal screen }\end{array}$ & Limit ember ignition of door and frame & Wood sliding door & $\mathrm{n} / \mathrm{a}$ & $\$ \$$ & None \\
\hline 25 & Wood-frame screen door & $\begin{array}{l}\text { Replace wooden screen door with metal } \\
\text { door and frame }\end{array}$ & $\begin{array}{l}\text { Limit ember ignition of screen door and } \\
\text { frame }\end{array}$ & Wooden screen door & $\begin{array}{l}\text { Primary door hardening option that does } \\
\text { not require primary door replacement }\end{array}$ & $\$ \$$ & None \\
\hline 26 & Plastic screen in screen door & Replace with metal screen (1/16 inch) & Prevent ignition from embers & $\begin{array}{l}\text { If screen door and frame are metal, } \\
\text { replace screen or entire system } \\
\text { (whichever is more cost effective). If } \\
\text { screen door or frame is wood, replace } \\
\text { entire screen door (see line above) }\end{array}$ & $\mathrm{n} / \mathrm{a}$ & $\$-\$ \$$ & None \\
\hline \multirow{3}{*}{27} & \multirow{3}{*}{ Garage door } & $\begin{array}{l}\text { If garage door is not metal, go over } \\
\text { with metal flashing around the bottom } \\
\text { of the door (both inside and outside for } \\
\text { first } 6 \text { inches (using a metal "C" } \\
\text { channel) }\end{array}$ & Prevent ignition from embers & Wooden garage door & $\mathrm{n} / \mathrm{a}$ & $\$-\$ \$$ & None \\
\hline & & $\begin{array}{l}\text { Add metal flashing at base of framing } \\
\text { for first } 6 \text { inches [go as close to the } \\
\text { ground as possible }(<1 / 4 \text { inch desired), } \\
\text { raise wood and extend flushing to } \\
\text { lower than bottom of wood] }\end{array}$ & Prevent ignition from embers & Wood garage door frame & $\mathrm{n} / \mathrm{a}$ & $\$-\$ \$$ & None \\
\hline & & Add gasketing & $\begin{array}{l}\text { Prevent ember intrusion and ignition from } \\
\text { embers }\end{array}$ & No gasketing & $\mathrm{n} / \mathrm{a}$ & $\$$ & Chapter 7A \\
\hline \multicolumn{8}{|c|}{ Attachments to Residence } \\
\hline \multirow[t]{2}{*}{28} & \multirow[t]{2}{*}{$\begin{array}{l}\text { Decks, stairs, and landings attached to } \\
\text { residence }\end{array}$} & $\begin{array}{l}\text { Replace walking surface deck boards } \\
\text { with noncombustible deck board for } \\
\text { first } 1 \mathrm{ft} \text { away from residence }\end{array}$ & \multirow[t]{2}{*}{$\begin{array}{l}\text { Prevent ignition of deck and limit spread of } \\
\text { fire to residence }\end{array}$} & \multirow[t]{2}{*}{$\begin{array}{l}\text { Combustible deck, stairs and landings } \\
\text { attached to residence }\end{array}$} & $\begin{array}{l}\text { 1. Area under the deck footprint must be } \\
\text { maintained with no combustibles, } \\
\text { addressed through defensible space } \\
\text { requirement } \\
\text { 2. Replacing boards that are not parallel } \\
\text { to the residence may require } \\
\text { additional deck framing }\end{array}$ & $\$-\$ \$$ & None \\
\hline & & $\begin{array}{l}\text { Replace entire deck with } \\
\text { noncombustible option (metal or other } \\
\text { option) }\end{array}$ & & & $\mathrm{n} / \mathrm{a}$ & $\$ \$ \$$ & $\begin{array}{l}\text { NFPA } 1140 \\
\text { ICC IWUIC }\end{array}$ \\
\hline 29 & Deck-to-wall intersection & $\begin{array}{l}\text { Replace bottom } 2 \mathrm{ft} \text { of combustible } \\
\text { siding with noncombustible (e.g., fiber } \\
\text { cement) and add metal flashing to } \\
\text { protect exposed sheathing }\end{array}$ & Limit ignition of wall on residence & Combustible siding & $\mathrm{n} / \mathrm{a}$ & $\$ \$$ & None \\
\hline 30 & $\begin{array}{l}\text { Combustible decks with combustibles } \\
\text { present in } 0 \mathrm{ft} \text { to } 5 \mathrm{ft} \text { zone around deck }\end{array}$ & $\begin{array}{l}\text { Remove combustibles in } 0 \mathrm{ft} \text { to } 5 \mathrm{ft} \\
\text { zone around deck }\end{array}$ & $\begin{array}{l}\text { Prevent flames from adjacent fuels from } \\
\text { igniting the deck }\end{array}$ & $\begin{array}{l}\text { Combustibles in } 0 \mathrm{ft} \text { to } 5 \mathrm{ft} \text { zone } \\
\text { around deck }\end{array}$ & $\mathrm{n} / \mathrm{a}$ & $\$$ & None \\
\hline 31 & Fence to residence & $\begin{array}{l}\text { Replace with noncombustible option } \\
\text { (metal or other option), minimum } 8 \mathrm{ft}\end{array}$ & Prevent ignition of combustible fence & Combustible fence & $\begin{array}{l}\text { This applies only to single fences; see } \\
\text { Table B Item \#10 for double fences }\end{array}$ & $\$-\$ \$$ & None \\
\hline \multirow[b]{2}{*}{32} & \multirow[b]{2}{*}{ Steps connected to residence } & $\begin{array}{l}\text { Introduce noncombustible } \\
\text { barrier/section between steps and } \\
\text { house, minimum } 1 \mathrm{ft}\end{array}$ & \multirow[b]{2}{*}{ Limit spread of fire to house } & Combustible steps & $\begin{array}{l}\text { This addressed top of deck ember ignited } \\
\text { scenario (not fire under steps/deck) }\end{array}$ & $\$$ & None \\
\hline & & $\begin{array}{l}\text { Introduce noncombustible } \\
\text { barrier/section between handrails and } \\
\text { residence or replace with } \\
\text { noncombustible handrail, minimum } 1 \mathrm{ft}\end{array}$ & & Combustible handrails & $\mathrm{n} / \mathrm{a}$ & $\$-\$ \$$ & None \\
\hline
\end{tabular}




\begin{tabular}{|c|c|c|c|c|c|c|c|}
\hline $\begin{array}{c}\text { Item } \\
\#\end{array}$ & $\begin{array}{l}\text { Structure Component, Assembly, or } \\
\text { Attached Combustible }\end{array}$ & Hardening Action & Performance Goal & Applicable Condition(s) & Notes & $\begin{array}{l}\text { Expected } \\
\text { Cost Range } \\
(\$, \$ \$, \$ \$ \$)\end{array}$ & $\begin{array}{l}\text { Matched in } \\
\text { Existing } \\
\text { Code }\end{array}$ \\
\hline 33 & Other attachments & $\begin{array}{l}\text { Introduce noncombustible } \\
\text { barrier/section between combustible } \\
\text { attachment and residence or replace } \\
\text { with noncombustible, minimum } 1 \mathrm{ft}\end{array}$ & Limit spread of fire to house & Combustible attachment & $\mathrm{n} / \mathrm{a}$ & $\$-\$ \$$ & None \\
\hline 34 & Attached retaining walls & $\begin{array}{l}\text { Replace retaining wall length equal to } \\
\text { two times retaining wall height with } \\
\text { noncombustible components }\end{array}$ & $\begin{array}{l}\text { Prevent flames from retaining wall from } \\
\text { igniting residence }\end{array}$ & $\begin{array}{l}\text { Combustible retaining wall within two } \\
\text { times the retaining wall height from } \\
\text { the residence }\end{array}$ & $\begin{array}{l}\text { Structural requirements of the retaining } \\
\text { wall must be maintained (must meet code) }\end{array}$ & $\$ \$$ & None \\
\hline 35 & Combustible furniture & $\begin{array}{l}\text { Replace furniture with noncombustible } \\
\text { framing materials or move away } 5 \mathrm{ft} \\
\text { (place cushions inside residence before } \\
\text { egress) }\end{array}$ & $\begin{array}{l}\text { Prevent flames from combustible furniture } \\
\text { from igniting residence }\end{array}$ & Combustible furniture on deck & Homeowner action item, required action & $\$$ & None \\
\hline 36 & Pergola/trellis & $\begin{array}{l}\text { Remove vegetation, detached from } \\
\text { residence, and have a } 2 \mathrm{ft} \text { open } \\
\text { space/separation from residence }\end{array}$ & $\begin{array}{l}\text { Prevent ignition of pergola/trellis from } \\
\text { igniting residence }\end{array}$ & Attached combustible pergola/trellis & $\begin{array}{l}\text { Structural integrity of pergola/trellis must } \\
\text { be maintained }\end{array}$ & $\$ \$$ & None \\
\hline \multicolumn{8}{|c|}{ Mobile Home Skirting/Crawl Spaces } \\
\hline 37 & Skirting & $\begin{array}{l}\text { Install mobile home noncombustible } \\
\text { skirting on all sides }\end{array}$ & $\begin{array}{l}\text { Prevent embers from igniting underside of } \\
\text { mobile home and prevent accumulation of } \\
\text { flammable (windblown) debris }\end{array}$ & $\begin{array}{l}\text { Mobile home without skirting or } \\
\text { without noncombustible skirting }\end{array}$ & $\mathrm{n} / \mathrm{a}$ & $\$ \$$ & None \\
\hline 38 & $\begin{array}{l}\text { Crawl space access hinged door with } \\
\text { clasp (door construction consistent } \\
\text { with cladding) }\end{array}$ & $\begin{array}{l}\text { Install crawl space access ember } \\
\text { intrusion protection }\end{array}$ & $\begin{array}{l}\text { Prevent embers from igniting materials in } \\
\text { crawl space and prevent accumulation of } \\
\text { flammable (windblown) debris }\end{array}$ & Access to crawl space & $\mathrm{n} / \mathrm{a}$ & $\$-\$ \$$ & None \\
\hline 39 & Crawl space vents & $\begin{array}{l}\text { Install ember and flame-resistant vents } \\
\text { if venting is required }\end{array}$ & $\begin{array}{l}\text { Minimize embers with enough energy to } \\
\text { cause ignitions }\end{array}$ & $\begin{array}{l}\text { New skirting with vents if needed } \\
\text { Non-ember-and flame-resistant vents } \\
\text { installed }\end{array}$ & $\begin{array}{l}\mathrm{n} / \mathrm{a} \\
\mathrm{n} / \mathrm{a}\end{array}$ & $\$-\$ \$$ & Chapter 7A \\
\hline \multicolumn{8}{|c|}{ Optional Work } \\
\hline 40 & Between deck boards & $\begin{array}{l}\text { Insert metal flashing between deck } \\
\text { boards at joists }\end{array}$ & Limit ignition of deck & Combustible deck and joists & $\mathrm{n} / \mathrm{a}$ & $\$-\$ \$$ & None \\
\hline
\end{tabular}

40 Between deck boards Insert metal
boards at joists

Combustible deck and joists

$\mathrm{a}$ If noncombustible gutter cover cannot be installed on combustible gutter, gutter must be replaced with a noncombustible mate
${ }^{\mathrm{b}}$ Vents need to account for reduction in air flow. If a vent is not fire and ember resistant it should be replaced with one that is.

${ }^{\mathrm{c}}$ Well-irrigated lawn may be allowed in the $0 \mathrm{ft}$ to $5 \mathrm{ft}$ around deck. (Item \# 30 ) 
Table B. Surrounding parcel hazard mitigation - hardening structure and attached combustibles against ignition from fire (radiation, convection).

Structure Separation Distance (SSD) or Slope and location of

Item Neighboring Parcel Exposure Distance

\# $(\text { NPED })^{\mathbf{a}}$

1 Proximity of closest neighboring primary residence(s) - SSD

\begin{tabular}{ll}
\hline & $\begin{array}{l}\text { Proximity to untreated wildland fuels - } \\
\text { NPED }\end{array}$
\end{tabular}

3 Proxim inity to treated wildland fuels ${ }^{\mathrm{c}}-$

Proximity to auxiliary buildings $>120 \mathrm{ft}^{2}$

in size (primary or neighboring parcel) -

Proximity to auxiliary buildings $64 \mathrm{ft}^{2}$ to $120 \mathrm{ft}^{2}$ (primary or neighboring parcel)SSD

Hardening Action

(on neighboring parcel) ${ }^{b}$

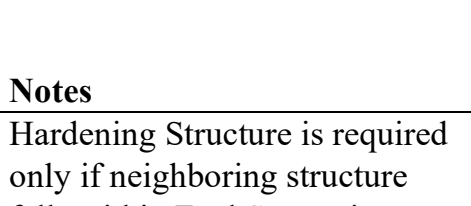

only if neighboring structure

falls within Fuel Separation

falls wit
Range
https://wwh

Slope of concern is between wildland fuel and structure (not

Assumes that slope has been

factored in the fuel treatmen

Aux. building hardening will need to

be treated as primary structure to

prevent ignition from fire (radiation)

and embers

Aux. building hardening will need to

be treated as primary structure to

prevent ignition from fire (radiation)

and embers

Aux. building hardening will need to

be treated as primary structure to

prevent ignition from fire (radiation)

https://www.fire.ca.gov/progra

space-prc-4291/

https://www.fire.ca.gov/media/

umkhhdbs/fuels-reductionguide-final-2021-print.pdf

Minimum Required

Minimum Required

Fuel Separation
Distance (MFSD) (ft)

Fuel Separation

Hardening Structure and Attached

Range

Combustibles Against Ignition from

Proximity to auxiliary buildings $<64 \mathrm{ft}^{2}$

size (primary or neighboring parcel) -

and embers

25 to 50

Required (in Table D) if $25<\mathrm{SSD}<50$

$100,150,200$

100

Required (in Table D) if NPED $<M F S D$

Required (in Table D) if $\mathrm{PED}<\mathrm{MFSD}$

25 to 50

Required (in Table D) if $25<\mathrm{SSD}<50$

20 to 40

Required (in Table D) if $20<\mathrm{SSD}<40$

15 to 30

Required (in Table D) if $15<\mathrm{SSD}<30$

Proximity to vegetative fuels not

compliant with defensive space ${ }^{\mathrm{d}}-$ NPED

Proximity of large auxiliary structures

and fuels (e.g., gazebo, RVs, boats) -

9 Proximity of small combustible auxiliary

structures (e.g., single fence) - NPED

Proximity of small combustible auxiliary

structures (e.g., double combustible
fences) - NPED

11 Proximity of detached retaining wall -

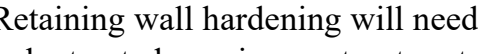

to be treated as primary structure to

and embers

${ }^{\mathrm{a}}$ From the edge of the house closest to the exposure.

${ }^{\mathrm{b}}$ If neighboring parcel is not part of the program, certain hardening actions may not be implementable and structure hardening may be necessary.

${ }^{\mathrm{c}}$ Wildland fuel treatment must have occurred within 3 years; must meet local, state, or federal guidance/standard.

${ }^{\mathrm{d}}$ Refers to vegetative fuels on adjacent properties. 


\begin{tabular}{|c|c|c|c|c|c|c|c|c|}
\hline $\begin{array}{c}\text { Item } \\
\#\end{array}$ & $\begin{array}{l}\text { Parcel Feature - } \\
\text { Exposure Distance (ED) or } \\
\text { Structure Separation Distance } \\
\text { (SSD) }\end{array}$ & Hardening Action & Performance Goal & Applicable Condition(s) & Notes & $\begin{array}{l}\text { Expected } \\
\text { Cost Range } \\
(\$, \$ \$, \$ \$ \$)\end{array}$ & $\begin{array}{l}\text { Minimum } \\
\text { Required Fuel } \\
\text { Separation } \\
\text { Distance } \\
\text { (MFSD) (ft) }\end{array}$ & $\begin{array}{l}\text { Hardening Structure } \\
\text { and Attached } \\
\text { Combustibles } \\
\text { Against Ignition from } \\
\text { Flames (radiation, } \\
\text { convection) }\end{array}$ \\
\hline 1 & Firewood - ED & $\begin{array}{l}\text { Replace firewood with other heating } \\
\text { source, displace firewood } 30 \mathrm{ft} \text { away from } \\
\text { main residence and other Table C features, } \\
\text { or store in a noncombustible enclosure } 15 \mathrm{ft} \\
\text { from Table C features }\end{array}$ & $\begin{array}{l}\text { Prevent firewood from } \\
\text { directly (flames) igniting } \\
\text { residence or other Table C } \\
\text { items }\end{array}$ & $\begin{array}{l}\text { If closer than recommended } \\
\text { separation distance }\end{array}$ & $\begin{array}{l}\text { Defensible space expanded to } \\
\text { account for all other Table } C \text { items }\end{array}$ & $\$$ & 30 & $\begin{array}{l}\text { Required (in Table D) } \\
\text { if ED<MFSD }\end{array}$ \\
\hline 2 & $\begin{array}{l}\text { Vegetative fuels not compliant } \\
\text { with defensible space - ED }\end{array}$ & Treat vegetation & $\begin{array}{l}\text { Defensible space } \\
\text { compliance }\end{array}$ & $\begin{array}{l}\text { Not in compliance with defensible } \\
\text { space }\end{array}$ & $\begin{array}{l}\text { If vegetative fuels reduction is not } \\
\text { possible, and ED is less than } \\
\text { distance specified in Table B for } \\
\text { untreated wildland fuels, residence } \\
\text { hardening will be required }\end{array}$ & $\$-\$ \$$ & $\begin{array}{c}100 \\
\text { (See Table B) }\end{array}$ & $\begin{array}{l}\text { Required (in Table D) } \\
\text { if ED<MFSD }\end{array}$ \\
\hline 3 & $\begin{array}{l}\text { Auxiliary buildings }\left(>120 \mathrm{ft}^{2}\right)- \\
\text { SSD }\end{array}$ & $\begin{array}{l}\text { Remove or separate } 50 \mathrm{ft} \text { from main } \\
\text { residence and other Table } \mathrm{C} \text { features or } \\
\text { harden the auxiliary building construction } \\
\text { in Table C and incorporate a } 0 \mathrm{ft} \text { to } 5 \mathrm{ft} \\
\text { ember-resistant zone. }\end{array}$ & $\begin{array}{l}\text { Prevent auxiliary building } \\
\text { from directly (flames) } \\
\text { igniting residence or other } \\
\text { Table C items }\end{array}$ & $\begin{array}{l}\text { If closer than recommended } \\
\text { separation distance }\end{array}$ & $\begin{array}{l}\text { If building removal, displacement, } \\
\text { or hardening of auxiliary structure } \\
\text { is not possible, residence } \\
\text { hardening will be required }\end{array}$ & $\$ \$-\$ \$$ & 50 & $\begin{array}{l}\text { Required (in Table D) } \\
\text { if SSD }<\text { MFSD }\end{array}$ \\
\hline 4 & $\begin{array}{l}\text { Small }\left(64 \mathrm{ft}^{2} \text { to } 120 \mathrm{ft}^{2}\right) \text { auxiliary } \\
\text { buildings }-\mathrm{SSD}\end{array}$ & $\begin{array}{l}\text { Remove, displace } 40 \mathrm{ft} \text { from main } \\
\text { residence, or harden the auxiliary building } \\
\text { construction (between } 5 \mathrm{ft} \text { to } 40 \mathrm{ft} \text { from } \\
\text { residence and other items in Table } \mathrm{C} \text { and } 0 \\
\mathrm{ft} \text { to } 5 \mathrm{ft} \text { ember-resistant zone }\end{array}$ & $\begin{array}{l}\text { Prevent auxiliary } \\
\text { structures from directly } \\
\text { (flames) igniting main } \\
\text { residence and other Table } \\
\text { C items }\end{array}$ & $\begin{array}{l}\text { If closer than recommended } \\
\text { separation distance }\end{array}$ & $\begin{array}{l}\text { If building removal, displacement, } \\
\text { or hardening of auxiliary structure } \\
\text { is not possible, structure hardening } \\
\text { will be required }\end{array}$ & $\$-\$ \$ \$$ & 40 & $\begin{array}{l}\text { Required (in Table D) } \\
\text { if ED<MFSD }\end{array}$ \\
\hline 5 & $\begin{array}{l}\text { Very small }\left(<64 \mathrm{ft}^{2}\right) \text { auxiliary } \\
\text { buildings }- \text { SSD }\end{array}$ & $\begin{array}{l}\text { Remove, displace } 30 \mathrm{ft} \text { from main } \\
\text { residence, or harden the auxiliary building } \\
\text { construction (between } 5 \mathrm{ft} \text { and } 30 \mathrm{ft} \text { ) from } \\
\text { residence and other items in Table C and } 0 \\
\mathrm{ft} \text { to } 5 \mathrm{ft} \text { ember-resistant zone }\end{array}$ & $\begin{array}{l}\text { Prevent auxiliary } \\
\text { structures from directly } \\
\text { (flames) igniting main } \\
\text { residence and other Table } \\
\text { C items }\end{array}$ & $\begin{array}{l}\text { If closer than recommended } \\
\text { separation distance }\end{array}$ & $\begin{array}{l}\text { If building removal, displacement, } \\
\text { or hardening of auxiliary structure } \\
\text { is not possible, structure hardening } \\
\text { will be required }\end{array}$ & $\$-\$ \$ \$$ & 30 & $\begin{array}{l}\text { Required (in Table D) } \\
\text { if } E D<M F S D\end{array}$ \\
\hline 6 & $\begin{array}{l}\text { Other combustible structures } \\
\left(>120 \mathrm{ft}^{2}\right) \text { (e.g., gazebo) - SSD }\end{array}$ & $\begin{array}{l}\text { Remove, displace } 50 \mathrm{ft} \text { from main } \\
\text { residence and other Table } \mathrm{C} \text { features, or } \\
\text { harden the auxiliary building construction } \\
\text { to noncombustible (If }<50 \mathrm{ft} \text { ) from other } \\
\text { items in Table C and incorporate } 0 \mathrm{ft} \text { to } 5 \mathrm{ft} \\
\text { ember-resistant zone }\end{array}$ & $\begin{array}{l}\text { Prevent fuels from } \\
\text { directly (flames) igniting } \\
\text { other (combustible) items }\end{array}$ & $\begin{array}{l}\text { If closer than recommended } \\
\text { separation distance and non- } \\
\text { hardened }\end{array}$ & $\begin{array}{l}\text { If building removal, displacement, } \\
\text { or hardening of auxiliary structure } \\
\text { is not possible; remove or displace } \\
\text { the other Table } \mathrm{C} \text { items or replace } \\
\text { with a new structure made of } \\
\text { noncombustible material. }\end{array}$ & $\$ \$-\$ \$$ & 50 & $\begin{array}{l}\text { Required (in Table D) } \\
\text { if SSD }<\text { MFSD }\end{array}$ \\
\hline 7 & $\begin{array}{l}\text { Large vehicles (e.g., RVs, boats) } \\
\text { - ED }\end{array}$ & $\begin{array}{l}\text { Remove, displace } 50 \mathrm{ft} \text { from main structure } \\
\text { and other Table } \mathrm{C} \text { features, and create a } 0 \mathrm{ft} \\
\text { to } 5 \mathrm{ft} \text { ember-resistant zone }\end{array}$ & $\begin{array}{l}\text { Prevent vehicles from } \\
\text { directly (flames) igniting } \\
\text { main residence and other } \\
\text { Table C items }\end{array}$ & $\begin{array}{l}\text { If closer than recommended } \\
\text { separation distance }\end{array}$ & $\begin{array}{l}\text { If vehicle removal or displacement } \\
\text { (beyond } 50 \mathrm{ft} \text { ) is not possible, } \\
\text { structure hardening will be } \\
\text { required }\end{array}$ & $\$$ & 50 & $\begin{array}{l}\text { Required (in Table D) } \\
\text { if ED<MFSD }\end{array}$ \\
\hline 8 & $\begin{array}{l}\text { Fences on property (see Table B } \\
\text { for distances) - ED }\end{array}$ & $\begin{array}{l}\text { Replace with noncombustible/ignition- } \\
\text { resistant materials (See Table B for } \\
\text { distances) }\end{array}$ & $\begin{array}{l}\text { Prevent fuels from } \\
\text { directly (flames) igniting } \\
\text { main residence and other } \\
\text { Table C items }\end{array}$ & $\begin{array}{l}\text { If combustible and closer than } \\
\text { recommended separation distance }\end{array}$ & $\begin{array}{l}\text { If replacement with } \\
\text { noncombustible/ignition-resistant } \\
\text { materials is not possible, structure } \\
\text { hardening will be required }\end{array}$ & $\$$ & $\begin{array}{c}10 \\
\text { (See Table B) }\end{array}$ & $\begin{array}{l}\text { Required (in Table D) } \\
\text { if ED<MFSD }\end{array}$ \\
\hline 9 & $\begin{array}{l}\text { Small combustibles within } 5 \mathrm{ft} \text { of } \\
\text { residence (e.g., door mat, planter, } \\
\text { garden hose) - ED }\end{array}$ & $\begin{array}{l}\text { Replace with noncombustible/ignition- } \\
\text { resistant materials or move away } 5 \mathrm{ft}\end{array}$ & $\begin{array}{l}\text { Prevent fuels from } \\
\text { directly (flames) igniting } \\
\text { main residence and other } \\
\text { Table C items }\end{array}$ & $\begin{array}{l}\text { If combustible and closer than } \\
\text { recommended separation distance }\end{array}$ & $\begin{array}{l}\text { If replacement with } \\
\text { noncombustible/ignition-resistant } \\
\text { materials is not possible, structure } \\
\text { hardening will be required }\end{array}$ & $\$$ & 5 & $\begin{array}{l}\text { Required (in Table D) } \\
\text { if ED<MFSD }\end{array}$ \\
\hline
\end{tabular}


Table D. Structure hazard mitigation - hardening structure and attached combustibles against ignition from fire (radiation, convection)

Structure Component

Item Exposure Distance (ED) or Structure

\# $\quad$ Separation Distance (SSD)

Performance Goal

Applicable Condition(s)

Dormer side

Replace non-Class A roofs by assembly

Prevent ignition of roof from flames

Non-Class A roo

Replace all combustib

Prevent ignition of dormer from

Combustible dormer siding

3 Dormer under eave

Replace all under eave construction with

Preven igilion of domer fion

Combustible dormer eave flames

Combustible dormer eave n/a

$\mathrm{n} / \mathrm{a}$

Replace with dual pane window with $\quad$ Prevent complete window failure ${ }^{\mathrm{a}} \quad$ Single pane or dual pane non-tempered $\quad \mathrm{n} / \mathrm{a}$

$\mathrm{n} / \mathrm{a}$

Add on top (of existing cladding) o replace with noncombustible cladding. Trim must be noncombustible

Prevent siding ignitio

Combustible cladding facing exposures

$5 \quad$ Exterior wall(s) including bump out(s)

If exposed framing, enclose with

oncombustible material. If enclosed

with combustible material, replace or

cover with noncombustible material.

Trim must be noncombustible and exten

$6 \quad$ Bump out bottom (underside)

(vertically) to account for added materia

7 Glazing in doors and glass sliding doors Double pane windows (both panes tempered)

prevent ignition under bump out(s) Combustible bump out(s) underside

material or exposed framin

1. Add on top option is available only
for residences with cladding that

have a flat profile.

. Add moisture barrier under new

Expected Matched in

Cost Range Existing

(\$, \$\$, \$\$\$) Code

Prevent complete window failure ${ }^{\text {a }} \quad \begin{aligned} & \text { double pane, or double pane with one } \\ & \text { tempered facing exposures in Table B } \\ & \text { and/or Table C }\end{aligned}$

and/or Table C

Prevent ignition in under eave area Under eave(s) combustible construction

enclose eave (angled) using $\quad$ and entry of fire in residence

Under eave(s) - overhanging
overhanging rake (gable end)

noncombustible material
Screen over entire window(s) (even if

window does not open) and other glazed

Reduce radiative exposures to glass

$9 \quad$ Screens

arfaces. Framing for screens must be of and possibly to parts of frame

All glazed surfaces facing exposures in $\quad \mathrm{n} / \mathrm{a}$

oncombustible material

Single pane non-tempered, non-tempered

Replace with dual pane window with

Prevent complete window failure

double pane, or double pane with one

both being tempered

and/or Table C

because of frame deformation (due to

heating)

prevent panes from being dislodged

$\$ \$ \$$

None

10 Windows

sure to other side(s))

Note: All sides of a structure must be hardened for fire and radiation unless a field in 


\section{Appendix B. Comparison of Existing Codes and Standards}

This appendix contains a tabulated list (Table $\mathbf{E}$ ) of detailed comparisons of primary solutions listed in three selected WUI building codes commonly used in the United States. The comparison is made with the most recent (2018 or 2019) editions of the International Wildland-Urban Interface Code, NFPA 1140/NFPA $1144,{ }^{13}$ and the California Building Code Chapter 7A. Note that each of these listed codes are regularly revised and improved varying temporal cycles.

There are multiple programs available to the public that can be used to reduce fuels and harden structures in the WUI [40]. Examples include NFPA's Firewise ${ }^{14}$ and CAL FIRE's Ready, Set, Go! ${ }^{15}$ programs which encourage defensible space and structure hardening. Depending on jurisdiction, these types of programs may be voluntary or mandatory and typically complement local, state, and national codes.

\footnotetext{
${ }^{13}$ NFPA codes are in transition to consolidate related codes. NFPA 1144 is a component of the new consolidated WUI code, NFPA 1140.

${ }^{14} \mathrm{https}$ ://www.nfpa.org/Public-Education/Fire-causes-and-risks/Wildfire/Firewise-USA

${ }^{15} \mathrm{https}$ ://www.readyforwildfire.org/prepare-for-wildfire/ready-set-go/
} 
Table E. Comparison of selected existing WUI building codes.

Building Component

Roof

\section{IWUIC (Ignition Resistant Construction Class 1)}

Specifies Class A fire rated covering (IR 2 specifies Class B, IR 3 specifies Class C). Requirements for "bird-stopping" / "fire stopping", including 72-pound cap sheet alternate method specified in Chapter $7 \mathrm{~A}$, also applies here. Requirements for thickness of metal when used in valley. Valley using metal flashing also requires use of 72-pound cap sheet underlayment.

Under-Eave

Eaves and soffits protected on exposed underside by one of four options, including 1) use of an Ignition Resistant Material or materials approved for a minimum one-hour fire-resistant-rated construction, 2) nominal 2-
inch lumber, or 1-inch nominal fire-retardant-treated lumber, or 3/4-inch inch lumber, or 1 -inch nominal fire-retardant-treated lumber, or 3/4-inch exterior use]. Open-eave or boxed in "ok", but both must comply with "underside" requirements. Fascia protected on back resistant material or materials approved for one-hour fire-resistancerated construction or nominal 2-inch lumber

Underfloor Enclosure

Where attached structure projects over a descending slope greater than $10 \%$, the area below the structure shall be enclosed to within 6 -inches of he ground with materials that comply with exterior wall requirements.

Gutters/Downspouts

pecifies gutter made of noncombustible materials (vinyl gutters not allowed). Gutters shall be provided with an approved means to prev

. Attic vent: Cannot be located in sotfit, eave ovenangs, between rafters, or in other overang areas. Gable end and dormer located minimum 10 prectical Individual vent openings not to located as close to grade with corrosion resistant mesh not to exceed 1/4-inch or designed and approved to prevent flame and ember penetration.
Roof covering assemblies tested and rated as Class A in accordance with ASTM E108 (or UL 790). Roof covering tested with all assembly components representing as-built condition (e.g., between panel joins must be present, and joints shall be in alignment with burning brand during test). When a roof profile provides for a gap between the roo covering and a combustible roof deck assembly shall include a 72-p cap sheet that complies with ASTM D3909 (Asphalt Roll Roofing (Glass Felt) Surfaced with Mineral Granules). The cap sheet shall be rolled out over the entire roof deck. In lieu of the use of such a roll roofing product, fire-retardant treated plywood can be used. Such ro coverings shall also be blocked at eaves, ridges, and hips with a istalled at all rake nd eave edges.

Specifies that eaves be enclosed with either 1) exterior FRT wood or ignition resistant material, or 2) a noncombustible material, or 3) a material hat, when tested to ASTM E2957 (under eave flame exposure test) complies with provisions provided in Section 5.3.4.1 (absence of combustion (flame or smoldering) after 40 minutes).

Noncombustible material. Gutters covered by approved noncombustible Neris.

Vents screened with corrosion-resistant noncombustible wire mesh, mesh opening not to exceed $1 / 8$-inch, or a vent that, when tested in accordance with ASTM E2886 comply with provisions found in Section form dryer vents.
Refers to Chapter 15 of the CBC. Chapter 15 specifies Class A covering in VHFHSZ, Class B in HFHSZ and Class C in MFHSZ. Specifies that any gaps between roof covering and roof deck be fire-stopped (e.g., birdstopped, fire-stopped). An alternate way to comply would be to install a minimum 72-pound cap sheet material over the decking. Specifies tha cap sheet that runs the full length of the valley.

Provisions are consistent with the provisions of the exterior wall requirements. Soffited eaves must be enclosed with either 1 ) noncombustible material, 2) ignition-resistant material, 3) use of 5/8inch Type $X$ gypsum sheathing in the assembly, 4) the exterior portio of a one-hour fire resistive wall assembly, or 5) complies with SFM nominal $2 \mathrm{x}$ dimension lumber is allowed (prescriptively).

Specifies that gutters be provided with the means to "prevent" the accumulation of leaves and debris. This section has generally been interpreted to mean "install a gutter cover device."

General requirement for vents to "resist building ignition from the intrusion of burning embers and flame through ventilation openings." intrusion of burning embers and laame through ventilation openings." with specified items (no flaming ignition of cotton [ember intrusion], no flaming ignition [flame intrusion], and maximum temperature on unexposed side of vent $<350^{\circ} \mathrm{C}\left[662^{\circ} \mathrm{F}\right]$ ), or mesh openings betwe 1/16-inch and 1/8-inch, noncombustible and corrosion resistant material. Vents not allowed on underside of eave unless 1 ) listed tested to ASTM E2886 and complying with stated provisions (above), or 2) AHJ permits vent as being resistant to flames and embers, or 3) attic is fully sprinklered or exterior cladding and underside of eave is noncombustible or approved IRM, and vent is more than 12 feet from ground or walking surface. 
Exterior Walls Exterior walls with one five methods, including 1) One-hour fireesistant-rated construction, 2) Approved noncombustible materials, 3) Heavy timber (o log wall contructon, 4) Fire retandant-treated wood on exterior side (rated for extenior use), or 5) lgnition-resistant materials on roof sheathing.

Windows

Exterior glazing (glass in windows) shall be, 1) tempered glass, multilayered glazed panels or 2) glass block, or 3) have a 20-minute fireresistance rating. These requirements also apply to skylights.

Applies to exterior windows, windows within exterior doors and skylights. All shall be tempered glass, multilayered glazed panels, glass shall be screened using noncombustible material. wentibliting a exhibiting a minimum Class B flame spread index (ASTM E84).

Provisions allow for AHJ to require enhanced protection. -- 6-inch vertical noncombustible zone (i.e., foundation)
Doors shall be 1) Noncombustible, 2) solid core wood (thickness of so core wood not less (han 1 3/4-inch), or 3) have at a minimum a 20 ing. Vehicle access (garage) doors are excluded.
Solid-core wood, $>1$ 3/4-inch thick, or be construction with noncombustible materials, or a "fire protection" rating of no less than 20
Objective is to resist building ignition and/or safeguard against intrusion of flames resulting from embers or short-term direct flame contact exposure. Included in "exterior wall" is under-eave and other horizont projections (with exception of attached deck). Exceptions include trim and fascia. Open eave construction also excepted as long as blocking an rafters have minith dim 707A 9]. Options Secions 707A.4, 707A.5, 707A.6, 707A.7, 707A.8, 2) ignitio Oplo for minimum nomina dimencion of 4 ince (ghconstruction assembly, or 5) test to ASTM E2707 or SFM Standard 12 7A-1 and complying with specified provisions. Two deemed-to-comply prescriptive options are also avilable, including 1) incorportion of onelayer 5/8-inch Type $\mathrm{X}$ gypsum board behind exterior cladding on exterior side of framing, or 2) exterior portion of 1-hour fire resistive exterior wall assembly. Assemblies listed in Gypsum Association Fire Resistance Design Manual are okay.

Exterior windows and exterior glazed door assemblies and skylights shall comply with one of the following: 1) multipane glazing with a minimum of one tempered pane meeting requirements of Section 2406 Safety Glazing, 2) glass block units, 3) fire resistance rating of not les than 20 minutes (NFPA 257 - using vertical furnace and timetemperature curve also described in ASTM E 119) or 4) meeting performance requirements of SFM 12-7A-2. Skylights also need noncombustible screening with minimum 1/8-inch mesh.

Exterior doors shall comply with one of the following: 1 and 2) exterio surface shall be noncombustible or ignition-resistant material, or 3) construction of solid core wood, stiles and rails not less than $13 / 8$-inch thick; raised panels not less than $1 \frac{1}{1} /$-inch thick except exterior perimeter of panel may taper to tongue not less than 3/8-inch thick, or 4) fire resistance rating on 20 minutes when tested in accordance to NFPA 252 , or 4 and 5) comply with performance requirements of SFM 12-7A-1/ ASTM E2707. Provision in Section 708 A.4 for minimizing intrusion of rating V-2 or better vi UL 94, Standard for Tests for Flammability of Plastic Materials for Parts in Devices and Appliances. 
Appendages (Decks) Unenclosed accessory structures attached to buildings with habitable spaces and projections shall have 1) One-hour fire resistant-rated construction, or 2) heavy timber, or either a) noncombustible material, b exterior rated fire-retardant treated wood, c) ignition resistant building materials. When an attached structure (such as a deck) extends over a descending slope greater than $10 \%$, the area below the structure
enclosed to within 6 -inches of the ground. Enclosing materials complying with "exterior walls" requirements.

Projections

1) Enclosed to ground ["exterior wall" requirements], or 2) "one-hour construction, or heavy timber, or exterior rated FRT wood.

When projections are attached to an exterior wall, the construction of the projection will be built to maintain the "fire-resistive" integrity of the vertical wall.

Including all projections (exterior balconies, carports, decks, patio covers, unenclosed roofs and floos shill be constructud of heavy timber or nonconbustible materials, or fie reandant treated wo gnition resistant nasials or be an, or fire re

This section only applies to the walking surface of the deck (porch, balcony, stairs, landings, included). Specifies that decking materia comply with one of the following: 1) Materials that are tested in accordance with boh ASTM E2632 (underdeck flame) and ASTM E2726 (top of deck brand) and comply with provisions found in Section E84), 3 (2) quali 12-7A-5 (similo 1 abo), or 4) ox bof or 5) noncos (sith 12-7A-4A (underdect fleme, oning PHRR only), Or tested to ASTM E2632 with acceptance criteria provided in Section 709A.5), with exception that Class B flame spread allows siding that complies with $7 \mathrm{~A}$ to be used. Allowable PHRR is $25 \mathrm{~kW} / \mathrm{ft}^{2}\left(\sim 276 \mathrm{~kW} / \mathrm{m}^{2}\right)$.

Provisions given for general case in Section 707A.2. Specific provisions are included for exterior porch ceilings, floor projections, underfloor projections, and the underside of appendages. Requirement options for these components include 1) noncombustible material, 2) ignitionresistant material, 3) one layer of Type $\mathrm{X}$ gypsum sheathing applied behind an exterior covering, 4) the exterior portion of an approved 1hour fire resistive exterior wall assembly or 5) complying with performance criteria of SFM 12-7A-3. When used in underfloo projections and appendages, heavy timber columns and beams do not require additional protection. When used in porch ceilings and floo projections, architectural trim boards do not need to comply. The minimum size to be considered heavy timber depends on the component.

No requirements for buildings more than $50 \mathrm{ft}$ from applicable building. Specifies that attached accessory structures shall comply with this section (states that strectuss shall be constructed of noncombustible or ignition-resistant materials); detached accessory structures within $50 \mathrm{ft}$
of the "applicable" building shall comply when required by the AHJ.

Iflocated less than $50 \mathrm{ft}$ from primary building, exterior wall of building to conform to "exterior walls" section. "Topography" language applies

"Enclos, if portion of structure projects over descending slope).

structural members protected by one-hour fire rating heavy timber, or

Constructed according to provisions outlined in this standard, or separated from primary building by at least $30 \mathrm{ft}$. .

1) Fence / fencing; 2) Clarification between "projections" "detached accessory structures" and "appendages"; 3) where to include small area out-buildings, such as a tool shed, that is located close to the primary building; 4) make sure the feature of being "attached" is addressed (structural or non-structural not so much an issue - proximity is the issue)"; 5) how much into "defensible space" issues do codes reach (e.g., providing requirements fo noncombustible retaining walls in down-slope areas) and other features that can enhance protection of the primary building of interest. 